\title{
Antigenicidad de Piensos y Materias Primas Proteicas en Conejos
}

\author{
Tesis Doctoral \\ José Luis Cano Muñoz
}

Director:

Dr. Enrique Blas Ferrer

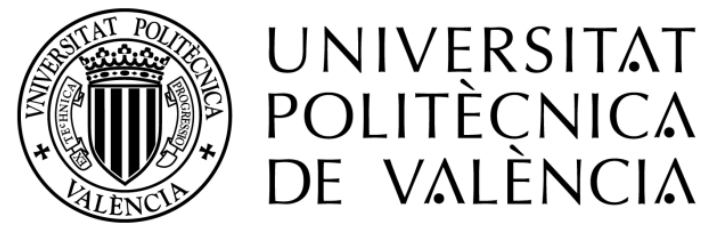

Departamento de Ciencia Animal

Febrero de 2016 

"No es la montaña a la que conquistamos sino a nosotros mismos"

Edmund Hillary, Monte Everest 1953, con Tenzing Norgay 

Para Diego, Merche y mi familia,

la única razón estadísticamente significativa

de todas las cosas 



\section{AGRADECIMIENTOS}

Son muchas las personas que me han ayudado a realizar este trabajo, para ellos mi reconocimiento y más sinceras gracias, ya que sin vuestra ayuda este trabajo no habría sido posible.

Alberto Arnau, Ana Heredia, Ana Pérez de Rozas, Concha Cervera, Cristina Casado, David Viana, Enrique Blas, Eugenio Martínez, Ignacio Badiola, Javier Moya, Josep Gasa, Juan Carlos Moreno, Juan José Pascual, Julio Fernández Carmona, Luis Ródenas, Mariano Domingo, y mis disculpas a los que por olvido no he nombrado y que han colaborado en este trabajo.

He de destacar a Enrique por su trabajo, dedicación y por su amistad que tanto me ha aportado.

También quiero destacar la ayuda de los miembros del Departamento de Ciencia Animal de la Universidad Politécnica de Valencia: Juanjo, Concha, Luis, Eugenio, Juan Carlos y Alberto, por acogerme en el departamento como uno más.

Y por supuesto a mi familia, a Merche y Diego, para el que espero que el conocimiento y la ciencia le den tantas satisfacciones como me han dado a mí.

A todos vosotros, mi más sincero agradecimiento. 



\section{RESUMEN}

La llegada masiva de antígenos dietarios es uno de los factores que intervienen en la problemática que se desarrolla en el destete de los animales productivos. Este hecho ha sido estudiado sobre todo en lechones y terneros, donde se ha visto que la respuesta inmunitaria frente a los antígenos dietarios y sus consecuencias varían según el origen de la proteína de la dieta, recomendándose en la práctica limitar el uso de materias primas proteicas de alta antigenicidad en la alimentación de los animales jóvenes. Sin embargo, en conejos, donde la problemática digestiva tras el destete es particularmente importante, apenas se dispone de información a este respecto.

El objetivo general del presente trabajo fue determinar si en conejos, al igual que ocurre en otras especies productivas, se producen reacciones inmunitarias frente a la dieta consumida, mediante la determinación en suero sanguíneo de inmunoglobulinas IgG específicas frente a antígenos dietarios, y comparar la antigenicidad de diferentes piensos y materias primas proteicas. Para ello se realizaron 3 experimentos. En el Experimento I se desarrolló el método de obtención de antígenos dietarios mediante hidrólisis pépsica y se comprobó mediante Dot Immunoblotting la presencia de anticuerpos IgG frente a antígenos dietarios en suero sanguíneo de conejos. En el Experimento II se desarrolló un ELISA indirecto para la determinación de IgG frente a antígenos dietarios en el suero sanguíneo. En el Experimento III se estudió la antigenicidad de diferentes materias primas proteicas determinando los anticuerpos IgG frente a los antígenos dietarios en suero sanguíneo mediante el ELISA indirecto desarrollado, así como los efectos de las mismas sobre la histomorfología e inmunohistoquímicos de la mucosa intestinal.

Con la metodología desarrollada: 1) se ha detectado la presencia de anticuerpos IgG frente a antígenos dietarios en el suero sanguíneo de conejas adultas y de gazapos estrictamente lactantes, 2) se ha comprobado que la respuesta de anticuerpos IgG frente a antígenos dietarios en el suero sanguíneo de los gazapos de cebo depende de la materia prima proteica incluida en el pienso que han consumido durante dicho periodo, siendo sensiblemente mayor con harina de girasol, gluten de trigo, guisante y harina de soja que con heno de alfalfa y, sobre todo, que con harina de pescado y 3) no se ha podido establecer una relación consistente de la respuesta de anticuerpos IgG frente a antígenos dietarios en suero sanguíneo ni con los parámetros histomorfológicos (altura de vellosidades, profundidad de criptas y ratio entre ellas) o inmunohistoquímicos (recuentos de linfocitos T en las vellosidades y de células en división en las criptas) de la mucosa yeyunal ni con el crecimiento durante el cebo. 



\section{ABSTRACT}

The massive intake of dietary antigens is one of the factors involved in the problems around the weaning of livestock species. This has been studied mainly in piglets and calves, which immune response to dietary antigens and their consequences varies depending on the origin of dietary protein, the use of protein raw materials of high antigenicity being in practice limited in the feeding of young animals. However, in rabbits, where digestive problems after weaning are particularly important, information in this regard is very scarce.

The overall objective of this study was to determine if, like in other livestock species, immune reactions against the diet also occur in rabbits, by determining IgG immunoglobulin specific to dietary antigens in blood serum, and to compare the antigenicity of different feeds and protein raw materials. Three experiments were performed. In Experiment $\mathrm{I}$, the method of obtaining dietary antigens by pepsin hydrolysis was developed and the presence of IgG antibodies against dietary antigens in rabbit blood serum was checked by Dot Immunoblotting. In Experiment II, an indirect ELISA to determine IgG against dietary antigens in blood serum was developed. In Experiment III, antigenicity of different protein raw materials was studied by measuring IgG against dietary antigens in blood serum by the indirect ELISA developed, as well as their effects on histomorphology and immunohistochemistry of the intestinal mucosa.

With the developed methodology: 1) the presence of IgG antibodies against dietary antigens in blood serum of adult and strictly suckling rabbits has been detected, 2) differing IgG antibody response against dietary antigens in blood serum of growing rabbits has been found depending on the protein raw material included in the feed they had consumed, being significantly higher with sunflower meal, wheat gluten, pea and soybean meal than with alfalfa hay and, especially, with fishmeal and 3) no consistent relationship of the $\lg G$ antibody response against dietary antigens in blood serum with histomorphological (villus height, crypt depth and ratio between them) or immunohistochemical ( $T$ cell counts in the villi and proliferating cells counts in the crypts) traits of the jejunal mucosa nor growth rate could be established. 



\section{RESUM}

L'arribada massiva d'antígens dietaris és un dels factors que intervenen en la problemàtica que es desenvolupa en el deslletament dels animals productius. Aquest fet ha estat estudiat sobretot en garrins i vedells, on s'ha vist que la resposta immunitària enfront dels antígens dietaris i les seves conseqüències varien segons l'origen de la proteïna de la dieta, recomanant-se a la pràctica limitar l'ús de matèries primeres proteiques d'alta antigenicitat en l'alimentació dels animals joves. No obstant això, en conills, on la problemàtica digestiva després del deslletament és particularment important, es disposa de poca informació referent al tema.

L'objectiu general del present treball va ser determinar si en conills, igual que ocorre en altres espècies productives, es produeixen reaccions immunitàries enfront de la dieta consumida, mitjançant la determinació en sèrum sanguini d'immunoglobulines IgG específiques enfront d'antígens dietaris, i comparar l'antigenicitat de diferents pinsos i matèries primeres proteiques. Per a això es van realitzar 3 experiments. En l'Experiment I es va desenvolupar el mètode d'obtenció d'antígens dietaris mitjançant hidròlisi pèpsica i es va comprovar mitjançant Dot Immunoblotting la presència d'anticossos IgG enfront d'antígens dietaris en sèrum sanguini de conills. En I'Experiment II es va desenvolupar un ELISA indirecte per a la determinació d'IgG enfront d'antígens dietaris en sèrum sanguini. En l'Experiment III es va estudiar l'antigenicitat de diferents matèries primeres proteiques determinant els anticossos IgG enfront dels antígens dietaris en sèrum sanguini mitjançant I'ELISA indirecte desenvolupat, així com els efectes de les mateixes sobre la histomorfologia i l'immunohistoquímica de la mucosa intestinal.

Amb la metodologia desenvolupada: 1) s'ha detectat la presència d'anticossos IgG enfront d'antígens dietaris en el sèrum sanguini de conilles adultes $i$ de llorigons estrictament lactants, 2) s'ha comprovat que la resposta d'anticossos IgG enfront d'antígens dietaris en el sèrum sanguini de conills d'engreixament depèn de la matèria primera proteica inclosa en el pinso que han consumit durant aquest període, sent sensiblement major amb farina de gira-sol, gluten de blat, pèsol i farina de soja que amb fenc d'alfals i, sobretot, que amb farina de peix i 3) no s'ha pogut establir una relació consistent de la resposta d'anticossos IgG enfront d'antígens dietaris en sèrum sanguini ni amb els paràmetres histomorfològics (alçada de vellositats, profunditat de criptes i ràtio entre elles) o immunohistoquímics (recomptes de limfòcits T en les vellositats i de cèl-lules en divisió en les criptes) de la mucosa jejunal ni amb el creixement durant l'engreixament. 



\section{ABREVIATURAS}

AGV Ácidos Grasos Volátiles

ALF Heno de alfalfa empleado en el Experimento III

BSA Albúmina sérica bovina

CD Moléculas de superficie celular para diferenciación de clusters

EGF Factor de crecimiento epidérmico

ELISA Enzyme Linked Immuno Sorbent Assay

GIR Harina de girasol empleada en el Experimento III

GLU Gluten de trigo empleado en el Experimento III

GUI Guisante empleado en el Experimento III

HA Hidrolizado del Pienso A empleado en los Experimentos I y II

HB Hidrolizado del Pienso B empleado en los Experimentos I y II

HALF Hidrolizado del heno de alfalfa granulado empleado en el Experimento III

HGIR Hidrolizado de la harina de girasol empleada en el Experimento III

HGLU Hidrolizado del gluten de trigo empleado en el Experimento III

HGUI Hidrolizado del guisante empleado en el Experimento III

HPES Hidrolizado de la harina de pescado empleada en el Experimento III

HSOJ Hidrolizado de la harina de soja empleada en el Experimento III

Ig Inmunoglobulina

IGF Factor de crecimiento insulínico

MS Materia Seca

PB Proteína Bruta

PBS Tampón fosfato salino

PES Harina de pescado empleada en el Experimento III

SOJ Harina de soja empleada en el Experimento III

TGF- $\boldsymbol{\beta}$ Factor de crecimiento transformante beta

TMB 3, 3', 5, 5'-Tetra Metil Benzidina 



\section{ÍNDICE}

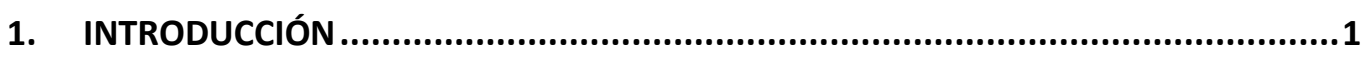

1.1. LOS ANTÍGENOS DIETARIOS EN EL DESTETE..................................................

1.2. DESCRIPCIÓN DEL SISTEMA INMUNITARIO INTESTINAL DEL CONEJO ...............5

1.3. VÍAS DE ENTRADA DE LOS ANTÍGENOS DIETARIOS POR LA MUCOSA

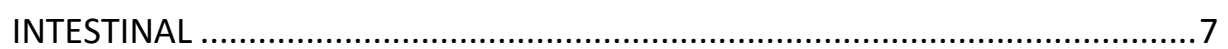

1.4. RESPUESTA INMUNITARIA FRENTE A ANTÍGENOS DIETARIOS:

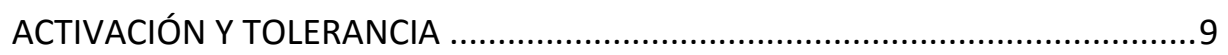

1.5. LAS IgG COMO MARCADORES DE LA REACCIÓN INMUNITARIA FRENTE A

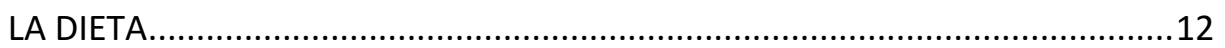

1.6. LA HOMEOSTASIS INMUNOLÓGICA INTESTINAL............................................14

1.7. PROBLEMÁTICA Y AVANCES EN LA ALIMENTACIÓN DE GAZAPOS EN TORNO AL DESTETE

2. OBJETIVOS 19

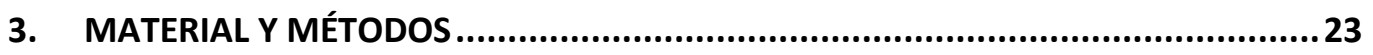

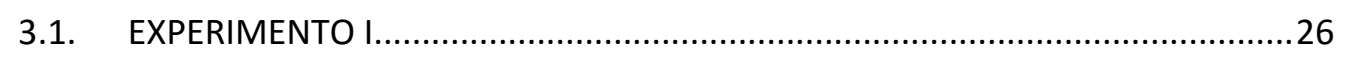

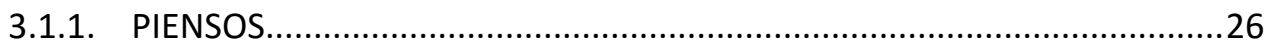

3.1.2. ANIMALES, MANEJO Y TOMA DE MUESTRAS ........................................27

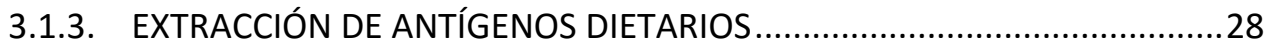

3.1.4. PROTOCOLO DE DOT IMMUNOBLOTTING PARA LA DETECCIÓN DE ANTICUERPOS IgG FRENTE A ANTÍGENOS DIETARIOS EN SUERO

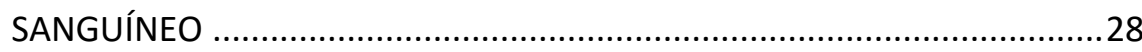

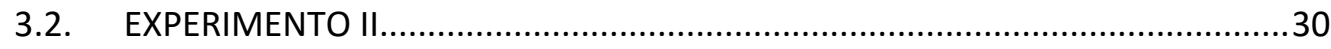

3.2.1. PIENSOS, ANIMALES, MANEJO Y TOMA DE MUESTRAS ........................30

3.2.2. EXTRACCIÓN DE ANTÍGENOS DIETARIOS...............................................30

3.2.3. MEDICIÓN DE LA PROTEÍNA DE LOS HIDROLIZADOS MEDIANTE EL

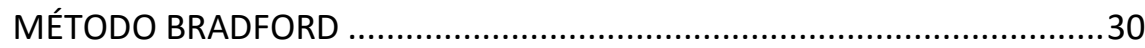

3.2.4. PROTOCOLO DE ELISA PARA VALORACIÓN DE ANTICUERPOS FRENTE ANTÍGENOS DIETARIOS EN SUERO SANGUÍNEO ........................31

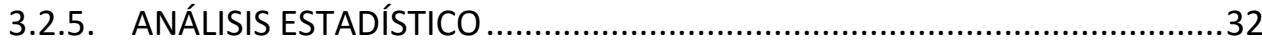

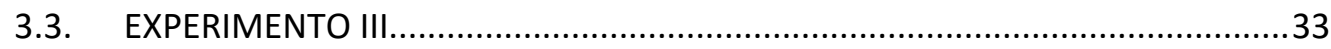

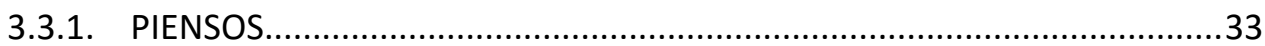

3.3.2. ANIMALES, MANEJO Y TOMA DE MUESTRAS .......................................... 
3.3.3. EXTRACCIÓN DE ANTÍGENOS DIETARIOS, MEDICIÓN DE LA PROTEÍNA DE LOS HIDROLIZADOS MEDIANTE EL MÉTODO BRADFORD Y PROTOCOLO DE ELISA PARA VALORACIÓN DE ANTICUERPOS IgG FRENTE A ANTÍGENOS DIETARIOS EN SUERO SANGUÍNEO

3.3.4. ANÁLISIS HISTOMORFOLÓGICO DE LA MUCOSA YEYUNAL ......................36

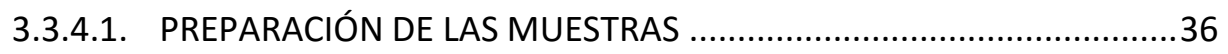

3.3.4.2. MEDICIÓN DE LA ALTURA DE LAS VELLOSIDADES Y LA PROFUNDIDAD DE LAS CRIPTAS DE LIEBERKÜHN ...........................37

3.3.5. ANÁLISIS INMUNOHISTOQUÍMICO DE LA MUCOSA YEYUNAL .................38

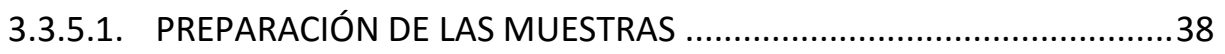

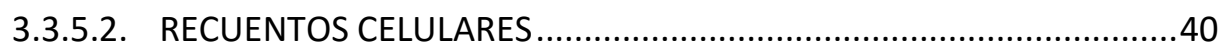

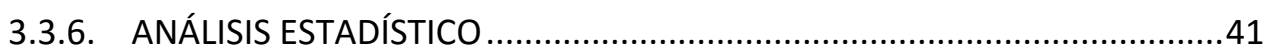

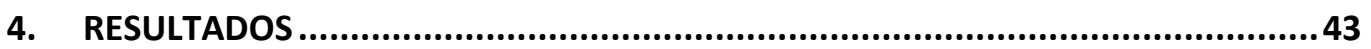

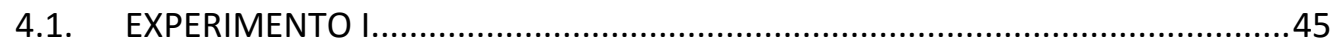

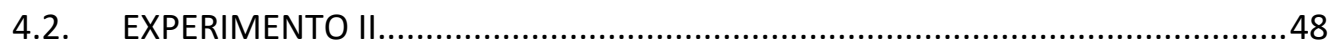

4.2.1. PUESTA A PUNTO DEL ELISA INDIRECTO PARA LA VALORACIÓN DE ANTICUERPOS IgG FRENTE A ANTÍGENOS DIETARIOS EN SUERO SANGUÍNEO .

4.2.1.1. AJUSTE DE LA CONCENTRACIÓN DE PROTEÍNA DE LOS

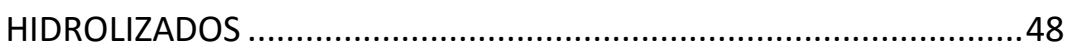

4.2.1.2. AJUSTE DE LA CONCENTRACIÓN DE LOS SUEROS...........................48

4.2.1.3. AJUSTE DE LA CONCENTRACIÓN DEL ANTICUERPO

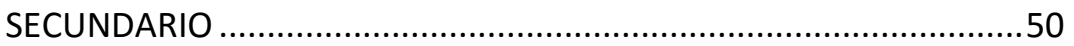

4.2.1.4. AJUSTE DEL TIEMPO DE INCUBACIÓN CON TMB ...........................51

4.2.1.5. ABSORBANCIA A $620 \mathrm{~nm}$ VERSUS ABSORBANCIA A $450 \mathrm{~nm}$...........52

4.2.2. ANTICUERPOS FRENTE A ANTÍGENOS DIETARIOS EN SUERO SANGUÍNEO DE GAZAPOS ALIMENTADOS CON LOS PIENSOS EXPERIMENTALES Y SUS MADRES......................................................53

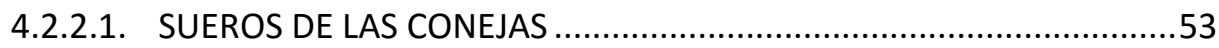

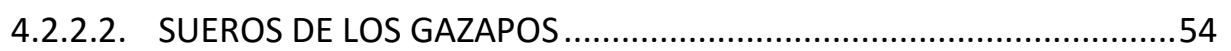

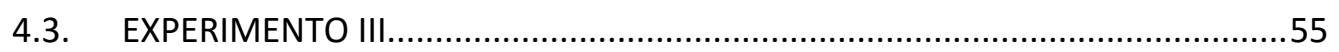

4.3.1. CONCENTRACIÓN PROTEICA DE LOS HIDROLIZADOS PÉPSICOS DE LAS FUENTES DE PROTEÍNA DIETARIA ….............................................55

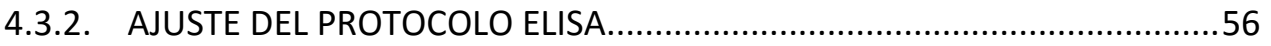

4.3.3. REPETIBILIDAD ENTRE PLACAS ELISA .................................................5 
4.3.4. ANTICUERPOS FRENTE A ANTÍGENOS DIETARIOS EN EL SUERO SANGUÍNEO DE GAZAPOS ALIMENTADOS CON LOS PIENSOS EXPERIMENTALES Y SUS MADRES.

4.3.4.1. SUEROS DE LAS CONEJAS ...........................................................5

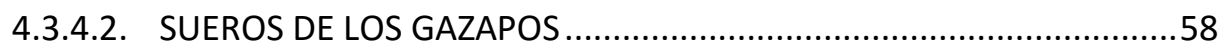

4.3.5. HISTOMORFOLOGÍA E INMUNOHISTOQUÍMICA DE LA MUCOSA

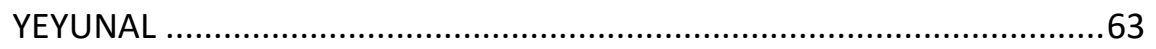

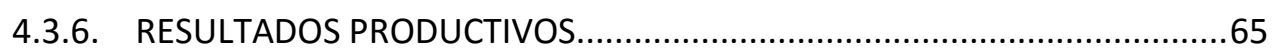

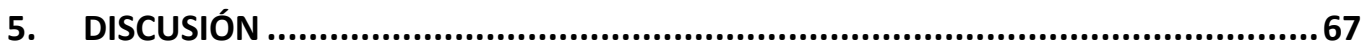

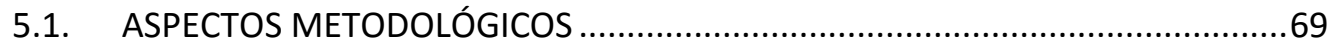

5.2. DETERMINACIÓN DE IgG FRENTE A LOS HIDROLIZADOS DE PIENSOS Y MATERIAS PRIMAS EN CONEJOS ..................................................................71

5.2.1. PRESENCIA DE IgG FRENTE ANTÍGENOS DIETARIOS EN EL SUERO DE CONEJAS ADULTAS

5.2.2. PRESENCIA DE IgG FRENTE A ANTÍGENOS DIETARIOS EN EL SUERO DEL GAZAPOS LACTANTES: TRANSFERENCIA MATERNA

5.2.3. EVOLUCIÓN DE LAS IgG FRENTE A ANTÍGENOS DIETARIOS EN EL SUERO DE LOS GAZAPOS EN CEBO: ANTIGENICIDAD DE LAS DISTINTAS MATERIAS PRIMAS PROTEICAS ..............................................75

5.3. EFECTO DE LOS PIENSOS SOBRE LA MUCOSA INTESTINAL.............................76

5.4. INFLUENCIA DE LOS PIENSOS SOBRE LOS RENDIMIENTOS PRODUCTIVOS.....80

6. CONCLUSIONES

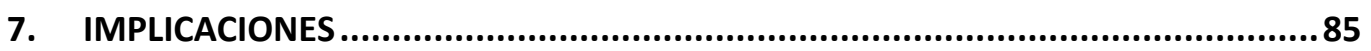

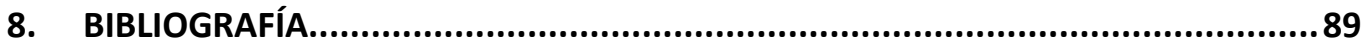



1. INTRODUCCIÓN 



\subsection{LOS ANTÍGENOS DIETARIOS EN EL DESTETE}

El destete es un momento crítico en los animales de producción intensiva, debido a la gran cantidad de cambios y factores estresantes que se concentran en este periodo, en el que con frecuencia se observa retraso del crecimiento y mayor incidencia de problemas digestivos (Lallès, 2008). Así, en el periodo del destete, durante la transición de una dieta a base de leche a una dieta sólida, los gazapos experimentan importantes cambios morfológicos y funcionales, relacionados con el desarrollo del tracto digestivo, la histomorfología de la mucosa intestinal, las actividades enzimáticas, la microbiota, su actividad fermentativa y el tejido linfoide asociado al intestino, que aumentan el riesgo de problemas digestivos (Gidenne y Fortun-Lamothe, 2002).

En los sistemas de producción animal intensiva se tiende a reducir el periodo de lactancia y adelantar el destete, realizado de una forma brusca cuando, como se ha mencionado, los animales no tienen totalmente desarrollado ni su sistema digestivo ni su sistema inmunitario. Por el contario, en la naturaleza el destete se produce de forma progresiva, reduciendo la ingestión de leche y aumentando la de alimento sólido de forma más paulatina. Así, por ejemplo, frente a los destetes precoces realizados con 3-4 semanas de vida en la producción porcina actual, los cerdos en condiciones de vida salvaje maman durante meses, lo que posibilita una exposición gradual a nuevos antígenos dietarios y un cambio progresivo de la microbiota intestinal (Bailey et al., 2001). Por el contrario, los sistemas productivos intensivos con destetes a edades tempranas exponen a los animales jóvenes a antígenos dietarios de forma prematura.

Para que los antígenos dietarios conserven su capacidad de desencadenar respuestas inmunitarias deben mantener sus epítopos antigénicos intactos durante el proceso digestivo. Las proteínas con capacidad antigénica tienen una masa molecular entre $10 \mathrm{y}$ $70 \mathrm{kDa}$ y dietas con proteínas hidrolizadas por debajo de $10 \mathrm{kDa}$ son efectivas para la reducción de la sintomatología de las alergias alimentarias en animales de compañía (Cave, 2006). Las proteínas de la soja con capacidad antigénica se encuentran entre 20 y $68 \mathrm{kDa}$ (Dréau et al., 1995a). Se ha señalado que, en general, los péptidos con menos de 12 aminoácidos pierden la capacidad antigénica (Tizard, 2013).

Se entiende por tanto que el propio proceso digestivo es un factor de protección para prevenir las respuestas inmunitarias frente a los alimentos, ya que hidroliza las proteínas contenidas en la dieta hasta oligopéptidos y aminoácidos que son absorbidos por la mucosa intestinal, y que los animales jóvenes con un sistema digestivo inmaduro sean más propensos a la presentación de problemas.

La digestión consta de una serie de procesos mecánicos, químicos y bioquímicos que permiten descomponer nutrientes macromoleculares en moléculas sencillas que puedan ser absorbidas y utilizadas por el animal. En el caso de las proteínas, el proceso digestivo comienza por medio de la pepsina gástrica, que básicamente transforma las proteínas en péptidos grandes. Tras este proceso actúan las proteasas pancreáticas, tripsina, 
quimotripsina, elastasa y endopeptidasas, que digieren los péptidos en mayor profundidad, originando oligopéptidos de hasta 6 aminoácidos (60\%) y aminoácidos libres (40\%) (Alpers, 1994). Finalmente, estos oligopéptidos llegan a los enterocitos, donde las peptidasas de las microvellosidades y citosólicas los hidrolizan hasta aminoácidos, dipéptidos y tripéptidos. Hasta el $85 \%$ de los aminoácidos absorbidos por los enterocitos aparecen en sangre de la vena porta en forma de aminoácidos libres (Krehbiel y Matthews, 2003).

A pesar del proceso digestivo, cantidades significativas de proteínas dietarias inmunológicamente activas llegan a la mucosa intestinal en porcino y en otras especies (Stokes et al., 2004). En humanos adultos sanos, se ha calculado que $10^{-5}$ de la dieta ingerida llega al intestino como antígenos intactos (Brandtzaeg, 2002). Asumiendo esta proporción en conejos, durante la vida de un animal de cebo que haya consumido aproximadamente $5 \mathrm{~kg}$ de pienso habrán llegado al intestino alrededor de $50 \mathrm{mg}$ de antígenos intactos.

Como en otras especies, la capacidad de los conejos para digerir la proteína de la dieta evoluciona con la edad. La secreción de pepsina comienza la primera semana de vida y su actividad en la mucosa gástrica aumenta hasta los 3 meses de vida (Dojana et al., 1998), aunque su actividad en el contenido gástrico no varió entre las 4 semanas y los 3 meses de vida (Marounek et al., 1995). En relación con las proteasas pancreáticas, se ha observado un incremento de la actividad de tripsina y quimotripsina en el páncreas entre la 3a y la 6a semana de vida (Lebas et al., 1971; Corring et al., 1972; Dojana et al., 1998; Debray et al., 2003), aunque la actividad de tripsina en el contenido intestinal disminuye durante la 4a semana de vida y luego se mantiene constante hasta la 7ạ semana de vida (Gallois et al., 2008), y la actividad de proteasas en el contenido intestinal no varió entre las 4 semanas y los 3 meses de vida (Marounek et al., 1995). Villamide et al. (2010) señalan que la digestibilidad ileal aparente de PB del pienso en gazapos de 35 días supone como media el $71 \%$ de la digestibilidad fecal aparente, mientras que la proporción en animales adultos es de $82 \%$ y $90 \%$ para forrajes y concentrados, respectivamente, lo que apoyaría la idea de que la digestión prececal de PB está limitada en animales jóvenes, que tendrían mayor exposición a antígenos dietarios.

Se sabe que el destete de los lechones provoca daños en la mucosa intestinal (Pluske et al., 1997). El daño se caracteriza principalmente por atrofia de las vellosidades, hiperplasia de las criptas, menor actividad enzimática en las microvellosidades y aumento de la permeabilidad paracelular a través de las uniones estrechas entre enterocitos. Este deterioro morfológico y funcional de la mucosa intestinal disminuye la disponibilidad de nutrientes y compromete su función de barrera. Para explicar el origen de estos efectos deletéreos se han postulado dos mecanismos no excluyentes. Por un lado, el daño sería la expresión de una respuesta inmune local transitoria al pienso (Miller et al., 1994; Bailey et al., 2001; Pié et al., 2004), cuya intensidad varía con el origen de la proteína dietaria (Touchette et al., 1997; Vente-Spreeuwenberg et al., 2004) 
y que podría considerarse como una inflamación local fisiológica, necesaria para que finalmente se establezca tolerancia (Newberry et al., 1999). Por otro lado, VenteSpreeuwenberg y Beynen (2003) señalan que los efectos negativos se deberían más al bajo consumo de pienso que a su composición, de tal manera que los distintos ingredientes solo tienen efectos marginales. Klis y Jansman (2002) indican que en el destete concurriría una respuesta inflamatoria aguda (aumento de la expresión mRNA de la citoquina proinflamatoria IL-1, menor ratio $\mathrm{CD} 4^{+} / \mathrm{CD} 8^{+}$de linfocitos $\mathrm{T}$ en la lámina propia de las criptas, correlación positiva entre los linfocitos $\mathrm{T} \mathrm{CD8} 8^{+}$en la lámina propia y la tasa de transporte paracelular, correlación negativa entre la altura y la anchura de las vellosidades y la población de linfocitos T en yeyuno e íleon) con la menor estimulación luminal y la desnutrición de los enterocitos provocadas por bajo consumo de pienso.

En gazapos, Gallois et al. (2005) observaron una reducción de la altura de las vellosidades y un aumento de la profundidad de las criptas en la mucosa yeyunal tras el comienzo de la ingestión de pienso, tanto si los gazapos estaban destetados como si permanecían lactantes. Según estos autores, tales cambios se deberían a la abrasión provocada por el inicio de la ingestión de pienso sólido, ya sea por acción mecánica, por hipersensibilidad transitoria frente a proteínas vegetales o por presencia de factores antinutritivos, mientras que la falta de leche (que contiene diversos factores de crecimiento y regeneración tisular) y la mayor ingestión de pienso asociada no serían determinantes. Sin embargo, Gutiérrez et al. (2002) no detectaron diferencias en la altura de las vellosidades o la profundidad de las criptas en la mucosa yeyunal entre los 25 y los 35 días de vida en animales lactantes, pero sí vellosidades más cortas y criptas más profundas en gazapos de 35 días de vida destetados a los 25 días, lo que avalaría el papel de la leche en el trofismo de la mucosa digestiva.

\subsection{DESCRIPCIÓN DEL SISTEMA INMUNITARIO INTESTINAL DEL CONEJO}

El sistema inmunitario intestinal cumple la doble misión de rechazar agentes patógenos y tolerar tanto la microbiota intestinal como los alimentos (Mason et al., 2008).

La función de defensa cuenta además con una serie de mecanismos de protección no inmunológicos como son la acidez gástrica, las uniones entre los enterocitos que previenen el paso de patógenos, el peristaltismo que reduce la capacidad de interacción entre las bacterias patógenas y la mucosa intestinal, la renovación constante de las células de la mucosa intestinal mediante la proliferación de las células pluripotenciales de las criptas, la producción de mucus por parte de las células caliciformes, las sustancias antimicrobianas secretadas por las células de Paneth (lactoferrina, lactoperoxidasa, lisozima y defensinas) y la microbiota saprófita residente en el tracto digestivo que despliega diferentes mecanismos de exclusión competitiva de bacterias patógenas (Neutra y Kozlowski, 2006; Delves et al., 2011). Estos mecanismos constituyen la primera línea de defensa y cuando no son suficientes para eliminar los 
agentes patógenos entran en juego los mecanismos inmunológicos. El sistema inmunológico intestinal tiene tantas células inmunitarias y produce tantos anticuerpos como el resto del organismo junto (Drouet-Viard y Fortun-Lamothe, 2002; CastroSánchez y Martín-Villa, 2013), lo cual da una idea de su enorme importancia en la defensa del organismo.

La organización del sistema inmunitario intestinal en el conejo es similar a la de otros mamíferos, salvo por la presencia de dos estructuras características de esta especie: el sacculus rotundus localizado en la unión ileocecocólica y el apéndice vermiforme de la parte caudal del ciego (Fortun-Lamothe y Boullier, 2007).

Desde un punto de vista estructural, el sistema inmunitario intestinal está constituido por el tejido linfoide asociado al intestino, que puede subdividirse en organizado y difuso (Castro-Sánchez y Martín-Villa, 2013).

En el conejo, el tejido linfoide intestinal organizado está constituido por los folículos linfoides aislados, las placas de Peyer, el sacculus rotundus y el apéndice vermiforme.

Los folículos linfoides son acúmulos de células linfoides localizados en la submucosa intestinal. Podemos diferenciar dos tipos. Los folículos linfoides simples tienen forma más o menos esférica, con un centro formado por linfocitos $B$ y una matriz formada por tejido conectivo y células dendríticas. Los folículos en cúpula tienen una estructura similar pero son de mayor tamaño y protruyen de la lámina propia en la luz intestinal. Estos folículos en cúpula contienen agrupaciones de linfocitos $\mathrm{B}$, linfocitos $\mathrm{T} \mathrm{CD}^{+}$, macrófagos y células dendríticas (Ermark et al., 1994). Están cubiertos por un epitelio especial diferenciado del resto del epitelio intestinal, llamado epitelio asociado a los folículos linfoides. Se diferencia porque no segrega mucus, IgA diméricas y fosfatasa alcalina (Owen y Bahalla, 1983; Pappo y Owen, 1988), tiene capacidad de unir lectinas (Neutra et al., 1987) y por la presencia de un gran número de células M. En el conejo, las células $M$ constituyen más del $50 \%$ de la células del epitelio asociado a los folículos linfoides (Pappo, 1989). En ratones también se ha descrito la presencia de células $M$ en el epitelio intestinal no asociado a los folículos linfoides, conocidas como células $M$ de las vellosidades intestinales (Jang et al., 2004).

Las células $M$ (microfold cells) son un tipo de células especializadas para la captación y transporte transepitelial de una gran variedad de macromoléculas, partículas y microorganismos (Castro-Sánchez y Martín-Villa, 2013), que entran en contacto con las células que se encuentran junto a ellas en la parte interna del epitelio. En concreto, estas macromoléculas, partículas y microorganismos son capturadas por las células presentadoras de antígenos (macrófagos y células dendríticas) permitiendo la activación de los linfocitos foliculares y la inducción de una respuesta inmunitaria específica (Siebers y Finlay, 1996).

Las placas de Peyer son agregaciones macroscópicas de folículos linfoides distribuidos en la submucosa del intestino delgado (Moens y Veldhoen, 2012). Los conejos tienen de 2 a 
10 placas de Peyer en el intestino delgado (Mage, 1998) y su estructura es similar a la de otras especies de mamíferos. Están formadas por numerosos folículos linfoides en cúpula que sobresalen en el lumen intestinal y difieren de los linfonódulos en que no tienen conductos linfáticos aferentes, lo que indica la especialización de esta estructura en la captación de antígenos del lumen intestinal a través del epitelio (Castro-Sánchez y Martín-Villa, 2013).

Además de folículos linfoides aislados y placas de Peyer, el conejo tiene dos estructuras específicas muy importantes en su sistema inmunitario intestinal: el sacculus rotundus y el apéndice vermiforme. Cada una de estas estructuras contiene varios cientos de folículos linfoides en cúpula organizados de forma muy similar a las placas de Peyer. Las vellosidades de estas estructuras son diferentes, con una forma peculiar, y se conocen como "vellosidades seta" (Mage et al., 1998).

El tejido linfoide intestinal difuso está formado por un gran número de células linfoides y no linfoides. Los linfocitos que se encuentran entre las células epiteliales se denominan linfocitos intraepiteliales y en su mayoría (80-90\%) son linfocitos T. Otros linfocitos están localizados en el tejido conectivo de la lámina propia y se denominan linfocitos de la lámina propia, entre los que hay linfocitos T (40-90\%) y linfocitos B que en una alta proporción están diferenciados a células plasmáticas y secretan IgA (Abreau-Martin y Targan, 1996). Las células no linfoides son granulocitos, macrófagos y células dendríticas que están diseminadas en la lámina propia, con una importante función en la captación de antígenos y en la activación de los linfocitos B para la producción de IgA (Granucci y Ricciardi-Castagnoli, 2003).

Funcionalmente, en el sistema inmunitario intestinal se distinguen sitios inductores, como el tejido linfoide organizado asociado a la mucosa intestinal y los linfonódulos locales, y sitios efectores, como la lámina propia, el estroma de las glándulas exocrinas y la superficie epitelial (Moens y Veldhoen, 2012).

\subsection{VÍAS DE ENTRADA DE LOS ANTÍGENOS DIETARIOS POR LA MUCOSA INTESTINAL}

Como ya se ha mencionado, la digestión de las proteínas también tiene por objeto prevenir la presencia en el intestino de moléculas con capacidad antigénica. Este proceso destruye la mayoría de los epítopos conformacionales de las proteínas, siendo un mecanismo de protección muy importante para promover la tolerancia mediante el proceso de exclusión antigénica (Untersmayr et al., 2003).

Pese a ello, una proporción de proteínas intactas o parcialmente digeridas penetran en la mucosa, dependiendo del tamaño, polaridad, estructura tridimensional y estado de degradación de las proteínas (Snoeck et al., 2005). 
La penetración de los antígenos a través de la mucosa intestinal puede ser vía paracelular (cuando se produce entre las uniones celulares) y vía transcelular (cuando se realiza a través de las células), como se ilustra en la Figura 1.

La vía paracelular es la entrada entre enterocitos adyacentes, que están unidos mediante uniones estrechas, uniones adherentes y desmosomas (Turner, 2009). Estas uniones permiten el paso de moléculas pequeñas $(<4 \AA \AA)$, pero también de moléculas mayores, como pequeños péptidos y lipopolisacáridos bacterianos entre 500 y 1500 Da (Perrier y Corthesy, 2011).

La vía transcelular se puede producir a través de varios tipos celulares: las células $\mathrm{M}$, los enterocitos y las células dendríticas (Perrier y Corthesy, 2011).

Como se ha indicado anteriormente, las células $M$ son células especializadas que se encuentran en un epitelio especial asociado a los folículos linfoides y tienen la capacidad de captar antígenos. Son una de las principales vías de acceso de bacterias, virus y antígenos dietarios al interior de la mucosa, donde entran en contacto con células del sistema inmune desencadenando respuestas inmunitarias.

Los enterocitos pueden captar y procesar macromoléculas mediante endocitosis. Los enterocitos expresan el complejo mayor de histocompatibilidad tipo II y pueden presentar antígenos a los linfocitos intraepiteliales (Snoeck et al., 2005). In vitro, los enterocitos también pueden producir exosomas que son vesículas que contienen antígenos unidos al complejo mayor de histocompatibilidad tipo II, con capacidad para transportar antígenos a través de la membrana basal, activar linfocitos $\mathrm{T}$ locales e inducir respuestas inmunes. Sin embargo, no está del todo demostrado que este mecanismo se produzca in vivo ni se conoce la importancia que pueda tener en el mantenimiento de la tolerancia oral (Van et al., 2003).

Una subpoblación específica de células dendríticas tiene capacidad de extender sus dendritas hasta el lumen intestinal y captar bacterias, particularmente en procesos inflamatorios (Rescigno et al., 2001). Se desconoce si esto ocurre también con antígenos dietarios y si puede contribuir al paso selectivo de antígenos a través de la mucosa intestinal y la activación de respuestas inmunes (Niess et al., 2005).

La vía de paso de los antígenos y las células que interviene determinan el tipo de reacción inmunitaria, siendo de vital importancia en los mecanismos de reacción y tolerancia. 


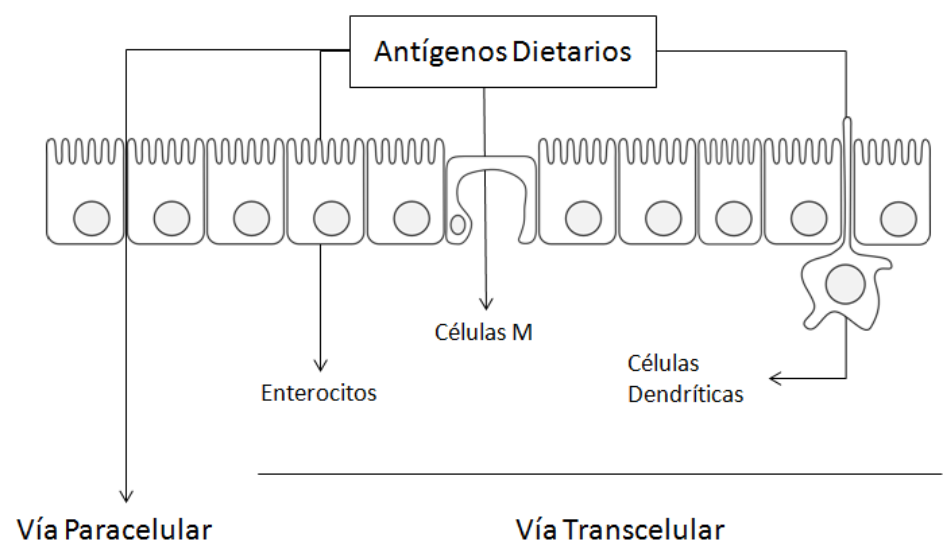

Figura 1. Vías de entrada de los antígenos dietarios

\subsection{RESPUESTA INMUNITARIA FRENTE A ANTÍGENOS DIETARIOS: ACTIVACIÓN Y TOLERANCIA}

La tolerancia inmunitaria oral es un mecanismo mediante el cual se modula la respuesta frente a antígenos no dañinos para el organismo y, dado que la mayoría de los antígenos que llegan a la mucosa intestinal no son peligrosos, la mayoría de las respuestas inmunitarias inducen tolerancia. Los mecanismos que intervienen en la tolerancia se pueden dividir en la exclusión antigénica que previene la entrada de los antígenos y las reacciones inmunitarias de tolerancia (Mason et al., 2008), que revisaremos a continuación.

La tolerancia oral es un complejo mecanismo todavía hoy no completamente entendido, que depende de múltiples factores como la genética, la edad, la estructura y composición del alimento, la dosis, momento y cadencia del consumo de antígenos, la naturaleza de los antígenos y su resistencia a las proteasas, la integridad de la barrera epitelial y el grado de activación inflamatoria. Este proceso está regulado principalmente a nivel del sistema inmunitario intestinal (Brandtzaeg, 2002).

Un factor que interviene de forma determinante en el desarrollo de una respuesta inmunitaria tolerante es la vía de entrada de los antígenos. Los antígenos insolubles y tipo partícula, como bacterias y virus, penetran principalmente a través de las células $M$ provocando potentes respuestas inmunitarias, mientas que los antígenos solubles penetran principalmente a través de los enterocitos produciendo reacciones de menor intensidad (Husby, 1988). En humanos, se ha visto que la $\alpha$-lactoalbúmina y la $\beta$ lactoglobulina, dos proteínas solubles de la leche, penetran en el intestino a través de los enterocitos provocando respuestas inmunitarias débiles. Si estas proteínas se insolubilizan mediante tratamiento térmico, su vía de entrada a través de la mucosa intestinal pasa a ser las placas de Peyer provocando una respuesta inmunitaria mucho más intensa, con una mayor producción de anticuerpos y citoquinas (Berin, 2012). 
En la Figura 2 se esquematizan las vías de entrada de los antígenos dietarios, así como los mecanismos de tolerancia y activación del sistema inmunitario.

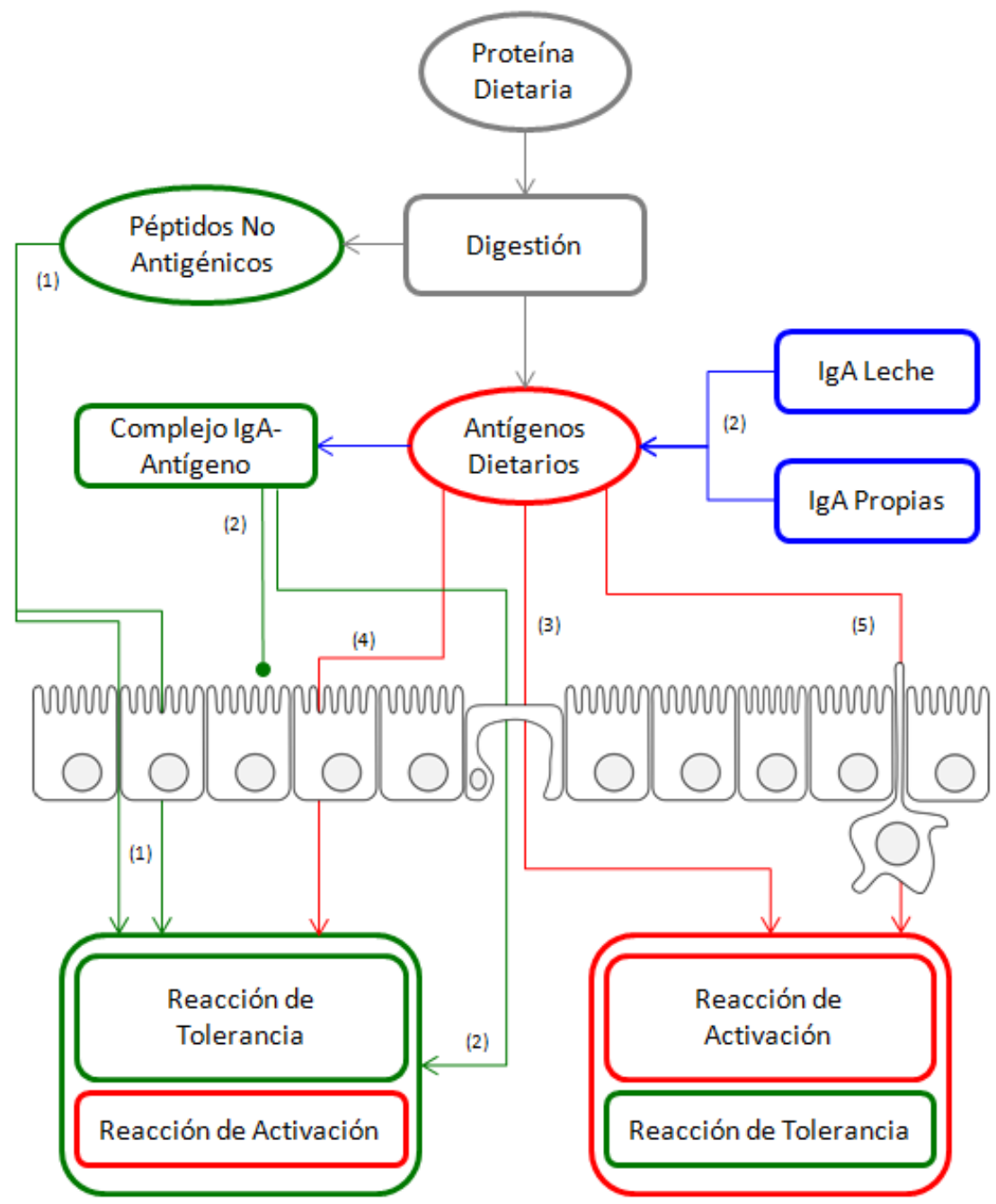

Figura 2. Vías de entrada de los antígenos dietarios, mecanismos de tolerancia y activación inmunitarias

(1) Mediante la digestión se rompen las proteínas dietarias en aminoácidos y oligopéptidos sin capacidad antigénica que son absorbidos por los enterocitos. Los péptidos de muy pequeño peso molecular pueden pasar a través de las uniones entre enterocitos. (2) A los antígenos que han resistido el proceso digestivo se les pueden unir IgA producidas a nivel intestinal por el propio individuo o procedentes de la leche materna en el caso de animales lactantes. Los complejos IgA-antígeno no pueden ser absorbidos pero pueden penetrar vía células $M$ provocando reacciones tolerogénicas. (3) Los antígenos dietarios que finalmente consiguen llegar al intestino pueden penetrar por las células $M$, siendo transferidos a las células presentadoras de antígenos que estimulan a los linfocitos desencadenando reacciones inmunitarias de tipo Th1 con la producción de IgG y citoquinas proinflamatorias. También es posible que por esta vía se produzcan reacciones de tolerancia mediante linfocitos reguladores (Th3 y Tr1). El balance entre una reacción y otra depende del tipo de antígenos, su cantidad y el estado inmunitario del individuo. (4) Los antígenos dietarios que penetran por los enterocitos provocan reacciones inmunitarias poco potentes ya que carecen de las moléculas coactivadoras de los linfocitos, provocando reacciones mayoritariamente de tolerancia mediante mecanismos de anergia y apoptosis. (5) Una subpoblación de células dendríticas tiene la capacidad de proyectar pseudópodos al interior de la luz intestinal y captar antígenos. La importancia de este mecanismo está por determinar, pero se trata de células especializadas en la presentación de antígenos con capacidad de estimular tanto reacciones inmunitarias intensas como de tipo tolerogénico 
La captación de antígenos a través de las células $M$ se produce mediante macropinocitosis, que transfiere los antígenos intactos al interior de la mucosa, donde se encuentran macrófagos y células dendríticas, que son células inmunitarias especializadas en el procesamiento y presentación de antígenos a los linfocitos, denominadas células profesionales presentadoras de antígeno. Estas células presentan el antígeno, unido al complejo mayor de histocompatibilidad tipo II y junto con moléculas coestimuladoras, a los linfocitos T CD4+ (linfocitos Th) y a los linfocitos B, que quedan sensibilizados y migran a los linfonódulos, donde proliferan. Desde allí, a través del conducto torácico, se distribuyen por todo el sistema epitelial del organismo, donde residirán como linfocitos intraepiteliales o linfocitos de la lámina propia, siendo células efectoras que permiten la puesta en marcha de la respuesta inmune en la mucosa digestiva. En el caso de antígenos procedentes de los alimentos, la respuesta preponderante es la reguladora, no inflamatoria, a cargo de linfocitos T reguladores (Th3 y Tr1), mientras que en el caso de agentes patógenos (virus, bacterias, hongos, helmintos) y altas dosis de antígenos dietarios se produce una respuesta de tipo Th1, Th2 o Th17 (Kagnoff, 1993). Las células Th3 son linfocitos Th productores de TGF- $\beta$ mientras que las células Tr1 son linfocitos Th diferenciados tras la presentación del antígeno por células dendríticas (pasando de $\mathrm{CD} 4^{+} \mathrm{CD} 25^{-}$a $\mathrm{CD} 4^{+} \mathrm{CD} 25^{+}$) y que producen IL-10. Estas subpoblaciones de linfocitos realizan su función reguladora de una forma no dependiente del antígeno, a través de las citoquinas, desempeñando un papel clave en el desarrollo de la tolerancia frente a antígenos dietarios y otros antígenos inocuos (Ramiro-Puig et al., 2008). Por otro lado, los linfocitos B de la lámina propia se transforman en células plasmáticas que segregan mayoritariamente $\lg \mathrm{A}$, que es la inmunoglobulina predominante en el intestino (Lamm, 1997). Estas IgA diméricas no activan el complemento ni inducen reacciones inflamatorias y juegan un importante papel en la protección de las mucosas, ya que son transportadas por los enterocitos al lumen intestinal, donde resisten la proteólisis y realizan una función de exclusión antigénica mediante su unión a antígenos y microorganismos, previniendo su contacto con la superficie intestinal (Fortun-Lamothe y Boullier, 2007).

Los enterocitos captan antígenos de la luz intestinal que son presentados a los linfocitos intraepiteliales y los linfocitos $\mathrm{T} \mathrm{CD4}^{+}$unidos al complejo mayor de histocompatibilidad tipo II pero de una forma incompleta, ya que los enterocitos no tienen las moléculas de coestimulación que poseen las células profesionales presentadoras de antígenos (Brandtzaeg, 2002).

Las células dendríticas emiten pseudópodos a través de los enterocitos hasta la luz intestinal donde captan antígenos. Comparado con las sistémicas, las células dendríticas intestinales presentas un fenotipo especial, con predisposición a desencadenar reacciones de tolerancia, principalmente estimulando linfocitos $T$ reguladores en la lámina propia y en los linfonódulos locales (Coombes y Powrie, 2008).

Otro factor importante que influye en la respuesta es la cantidad de antígeno dietario consumido y captado por la mucosa intestinal. Generalmente se acepta que la cantidad 
de antígeno determina el tipo e intensidad de reacción inmunitaria, pero hay trabajos con resultados contradictorios a este respecto. Por un lado encontramos que altas cantidades de antígenos dietarios provocan tolerancia vía anergia y apoptosis mientras que otros estudios apuntan que bajas cantidades de antígenos dietarios inducen tolerancia mediante linfocitos $T$ reguladores. La respuesta al consumo de altas cantidades de antígenos dietarios puede variar desde su ausencia hasta la inducción de inmunoglobulinas específicas como IgG e IgA en grandes cantidades. Estas diferencias se atribuyen a factores como la genética, la naturaleza del antígeno y su resistencia a la digestión (Perrier y Corthesy, 2011).

El desarrollo de la tolerancia oral en animales productivos ha sido poco estudiado, ya que los trabajos se han centrado más en los efectos de los antígenos dietarios sobre la productividad, la morfología intestinal y la salud digestiva. En el momento del destete, los lechones parecen no estar preparados para desarrollar una respuesta inmunitaria adecuada a los antígenos dietarios, como indica la aparición de problemas de diarrea, falta de crecimiento y alteraciones morfológicas de la mucosa intestinal (Bailey et al., 2001). En lechones de 3 semanas de edad la respuesta a la introducción de soja en el alimento es comparable a la respuesta cuando se inyecta con adyuvante (Bailey et al., 1994) mientras que en animales de mayor edad se observa una respuesta limitada. La capacidad de los lechones para desarrollar respuestas de tolerancia frente a los antígenos dietarios no está bien establecida hasta las 9 semanas de vida (Miller et al., 1994).

\subsection{LAS IgG COMO MARCADORES DE LA REACCIÓN INMUNITARIA FRENTE A LA DIETA}

Los estudios de inmunohistoquímica indican que el $80 \%$ de las células plasmáticas productoras de anticuerpos están en el intestino. En humanos, un $80 \%$ producen IgA, un $15-20 \% \operatorname{lgM}$ y un $3-4 \% \lg$.

Los constituyentes antigénicos de la dieta y la microbiota estimulan el sistema inmune secretor que son los linfocitos B del intestino. Así, los ratones alimentados parenteralmente muestran un reducido número de linfocitos $B$ y $T$ en el intestino, así como menor producción de IgA, que también se observa en ratones axénicos y que queda normalizada tras 4 semanas de administrar una dieta convencional (Brandtzaeg, 2002). Como ya se ha indicado, las IgA tienen un efecto protector de la mucosa bloqueando agentes patógenos y antígenos en el lumen intestinal.

La presencia de IgG frente a proteínas dietarias es un fenómeno común en humanos (Husby, 2000), señalándose que su nivel circulante tiene valor predictivo en cuanto el establecimiento de tolerancia oral y que carece de valor diagnóstico en los problemas de alergias alimentarias (Hofmaier et al., 2014). 
La presencia de IgG frente a antígenos de la dieta también se ha estudiado en animales de producción, principalmente en lechones y terneros frente a la soja (Bailey y Haverson, 2006). Los problemas por el uso de soja se asocian a la presencia de factores antinutricionales y proteínas antigénicas como glicinina y $\beta$-conglicinina (Huisman y Jansman, 1991). Incluso si los factores antinutricionales son inactivados mediante tratamientos térmicos, los problemas continúan apareciendo y solo se resuelven cuando se realizan tratamientos de desnaturalización con etanol o hidrólisis para la reducción de la capacidad antigénica de la soja (Stojanovic et al., 2010).

Así, los lechones alimentados con un pienso basado en harina de soja presentan niveles de IgG anti-soja en suero sanguíneo considerablemente más altos que los alimentados con piensos formulados a base de leche descremada o diferentes tipos de concentrados proteicos de soja, sin que haya correlación entre los niveles de IgG anti-soja circulantes y la ganancia media diaria durante dicho periodo (Li et al., 1991a). Sin embargo, con la misma metodología, Dréau et al. (1994) no observaron diferencias en el nivel de anticuerpos anti-soja entre lechones alimentados con piensos formulados a base de harina de soja o de concentrado proteico de soja considerado no antigénico por estar libre de glicinina y $\beta$-conglicinina.

Por otro lado, solo los lechones de más de 4 semanas son capaces de producir IgG antisoja y su presencia en la sangre de lechones más jóvenes no se debe a una respuesta inmunitaria propia sino a la transferencia de inmunidad pasiva por parte de la cerda, como demuestra que el nivel sea máximo en el primer día de vida y disminuya claramente durante las primeras semanas de vida (Hankins et al., 1992; Dréau et al., 1994). Esta transferencia pasiva de anticuerpos anti-soja de las madres a la descendencia también se ha verificado en ratones (Christensen et al., 2004). Se produce a través del consumo de calostro, muy rico en IgG, en las primeras horas después del parto, cuando el intestino todavía tiene la capacidad de absorber IgG intactas. En el caso de los conejos, la transferencia también se realizaría vía placentaria al final de la gestación, ya que la placenta es hemocorial y permite el paso de inmunoglobulinas de la madre a los fetos.

De forma análoga, los terneros prerumiantes alimentados con lactoreemplazantes a base de harina de soja presentaron niveles de $\lg G$ e $\lg A$ específicas frente al alimento más altos que los alimentados con lactoreemplazantes a base de concentrado proteico de leche o aislado proteico de soja hidrolizado, tanto a nivel local (en la secreción mucosa) como en sangre (Dréau et al., 1995a). Asimismo, Lallès et al. (1995b) observaron un mayor nivel de anticuerpos frente a la dieta circulantes en terneros prerumiantes alimentados con lactoreemplazantes a base de harina de soja 0 concentrado de soja convencionales que cuando tales productos eran desprovistos de su capacidad antigénica mediante tratamientos físico-químicos adicionales.

La información sobre otras materias primas usadas en alimentación animal que puedan producir respuestas inmunitarias e IgG específicas en sangre es escasa. En lechones, se 
ha comprobado que otras leguminosas diferentes de la soja, como guisantes, habas, altramuces o garbanzos, también inducen la presencia de IgG específicas circulantes en mucha mayor medida que la caseína (Salgado et al., 2002a).

Otros trabajos han mostrado que las proteínas de trigo también provocan respuestas inmunitarias y presencia de IgG específicas circulantes. Así se ha observado en terneros alimentados con raciones que contenían aislados de proteína de trigo (Timmermans et al., 1992) y en conejos de laboratorio alimentados con dietas con salvado de trigo, que presentaron niveles de IgG circulantes frente a gluten de trigo y gliadina tan altos como los conejos inmunizados con gluten de trigo por vía parenteral, mientras que los títulos anti-gluten en conejos silvestres eran mucho menores (March, 2003). Sin embargo, en este mismo trabajo no se detectaron anticuerpos anti-gliadina en sueros de ratones alimentados con dietas con trigo, lo que indicaría que la respuesta inmunitaria frente a las proteínas de la dieta varía entre especies.

\subsection{LA HOMEOSTASIS INMUNOLÓGICA INTESTINAL}

Los efectos que la llegada masiva de antígenos dietarios en el momento del destete puede tener sobre el sistema inmunitario, tanto a corto como a largo plazo, se han estudiado más en profundidad en lechones. Bailey et al. (2001) propusieron un modelo explicativo del desarrollo del sistema inmunitario intestinal del lechón basado en el equilibrio entre las respuestas inmunitarias efectora y reguladora. Para preservar la digestión y la absorción intestinal, el sistema inmunitario intestinal debe desarrollarse de forma controlada, para que en todo momento sea capaz de discriminar los antígenos inocuos de los dañinos y responder de la forma adecuada frente a cada uno de ellos. Este desarrollo ocurre en un equilibrio entre las funciones efectora y reguladora, de forma que la integridad intestinal depende de que este equilibrio se mantenga dentro de unos límites de seguridad (Figura 3, a).

En el momento del destete se produce una alteración de la homeostasis inmunológica por llegada de antígenos dietarios, establecimiento de la microbiota intestinal, contacto con patógenos, desaparición de los anticuerpos maternales y de los factores de crecimiento y regeneración epitelial contenidos en la leche (TGF- $\beta$, EGF, IGF y poliamidas) y otros cambios fisiológicos derivados del estrés ambiental, de forma que los problemas asociados al destete serían el resultado de un desequilibrio transitorio entre las funciones efectora y reguladora. Por un lado, una estimulación excesiva de la función efectora frente a antígenos inocuos es inapropiada, porque daría lugar a daños intestinales transitorios (Figura 3, b). Por otro, el desarrollo excesivo de la función reguladora frente a antígenos microbianos aumentaría el riesgo de infección por agentes patógenos o de sobrecrecimiento de bacterias no patógenas (Figura 3, c). 

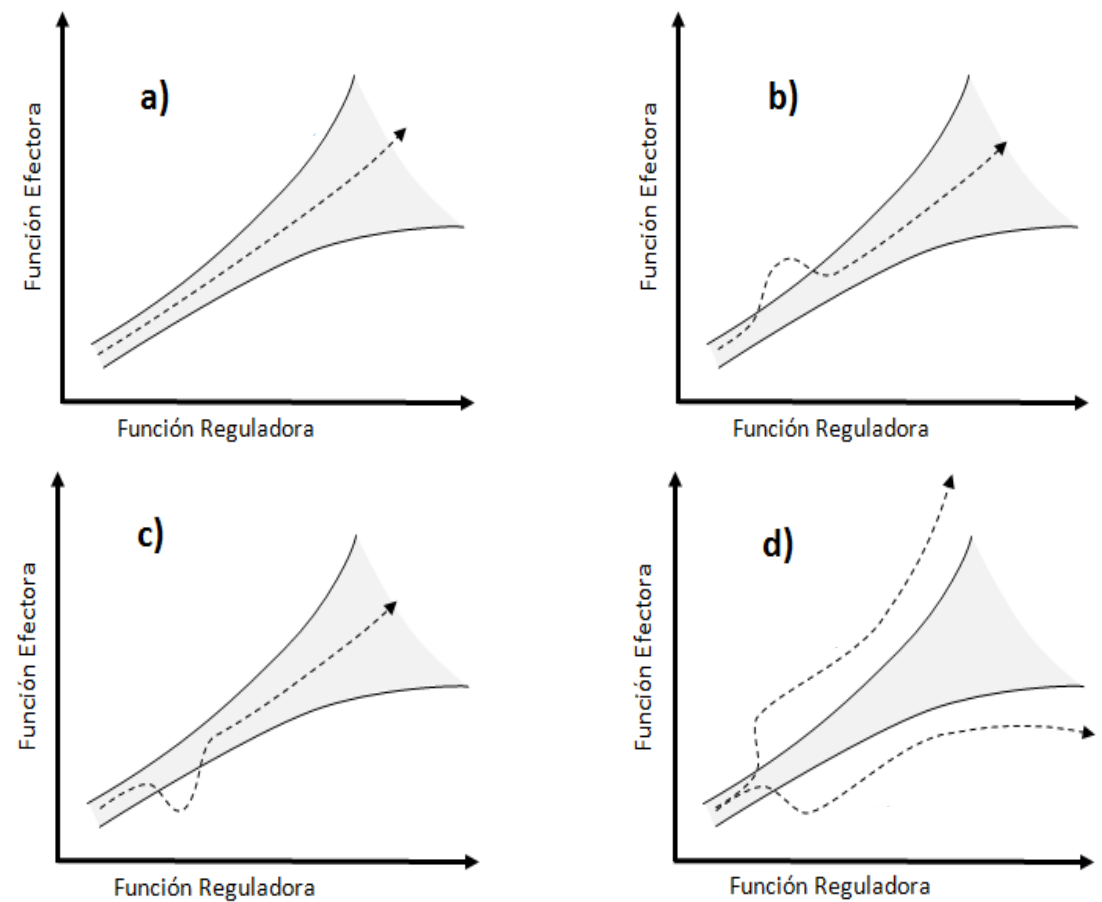

Figura 3. Modelo de homeostasis inmunológica intestinal adaptado de Bailey et al. (2001)

En condiciones normales estas desviaciones son transitorias y la homeostasis inmunológica se restablece. Sin embargo, dependiendo de factores genéticos o ambientales, el desequilibrio de las respuestas efectora y reguladora del sistema inmunitario intestinal puede ser permanente, de forma que los animales estarían predispuestos a padecer alergias alimentarias (exceso de función efectora) o infecciones crónicas (exceso de función reguladora) (Figura 3, d).

\subsection{PROBLEMÁtICA Y AVANCES EN LA ALIMENTACIÓN DE GAZAPOS EN TORNO AL DESTETE}

La rentabilidad de la producción de carne de conejo pasa por optimizar la influencia de la alimentación sobre el rendimiento productivo y la salud de los animales. A este respecto, uno de los problemas principales es la elevada mortalidad que se produce durante el periodo de cebo de los conejos debido, principalmente, a las patologías digestivas, causantes del 60\% de la mortalidad en dicho periodo (Rosell, 1996).

En general, la alimentación no debe considerarse como causa primaria de problemas digestivos si se respetan las recomendaciones establecidas en materia tanto de niveles de nutrientes, como de control de calidad de las materias primas y del proceso de fabricación del pienso. La dieta se ha considerado como un factor epidemiológico de 
riesgo, haciendo esencial la optimización de la formulación de piensos para gazapos, orientados a promover un correcto desarrollo morfológico, fisiológico, inmunológico y de la microbiota del tracto intestinal. En efecto, es presumible que las necesidades nutritivas de los gazapos en torno al destete sean muy específicas, en particular si el objetivo es optimizar su salud gastrointestinal. Sin embargo, a diferencia de lo que ocurre en otros mamíferos de interés productivo, los gazapos no reciben un pienso específico para este periodo sino que consumen piensos diseñados para atender las necesidades de conejas lactantes (antes del destete) o de conejos de cebo (después del destete). Es por ello que buena parte de la investigación en nutrición de conejos realizada en los últimos 15 años se ha centrado en tres aspectos, la optimización de la composición del pienso para gazapos en pre o/y postdestete, la restricción alimentaria en postdestete y el retraso de la edad al destete (Martínez-Vallespín, 2012), así como en la utilización de ciertos aditivos (enzimas, acidificantes, prebióticos y probióticos) como alternativa a los antibióticos (Falcao-e-Cunha et al., 2007).

La mayor parte de los trabajos que han abordado los efectos de la composición del pienso en la salud digestiva de los gazapos han estudiado la influencia del nivel y naturaleza de la fibra y, en menor medida, del almidón sobre la morfología y función de la mucosa intestinal o el tránsito digestivo, el ambiente cecal y la microbiota digestiva, tal como ha sido recientemente revisado (Soler, 2014).

En lo que concierne a la proteína, se sabe desde hace tiempo que elevar el contenido en PB por encima de las recomendaciones establecidas aumenta el riesgo de problemas digestivos, ya que podría producir un aumento del flujo de PB hacía el ciego que favorecerían la prevalencia y proliferación de bacterias proteolíticas potencialmente patógenas, como Clostridium y Escherichia coli (Haffar et al., 1988; Cortez et al., 1992), particularmente al comienzo del cebo, cuando la capacidad para la digestión intestinal de las proteínas parece estar menos desarrollada. En los últimos 15 años, se han realizado distintos estudios para conocer mejor y tratar de ajustar más las necesidades proteicas de los conejos en crecimiento, considerando particularmente los efectos sobre la salud digestiva tanto del nivel como de la fuente de proteína.

Chamorro et al. (2007) observaron que la reducción del contenido proteico se acompañó de menor flujo ileal de PB, menor frecuencia de detección de Clostridium perfringens en la digesta ileal y menor mortalidad. En un estudio a gran escala en condiciones de campo, Gidenne et al. (2013) también observaron que la reducción del contenido proteico disminuyó la mortalidad, aunque el cambio dietario no afectó a la concentración de AGV totales o de $\mathrm{NH}_{3}$ ni al pH del ciego. Xiccato et al. (2011) observaron que la reducción del contenido proteico disminuyó la concentración cecal de AGV totales pero no afectó a la de $\mathrm{NH}_{3}$ ni al pH o la morfología de las vellosidades intestinales, con efectos sobre la mortalidad que variaron dependiendo de los contenidos concomitantes en fibra soluble y almidón. En un estudio a gran escala con piensos peridestete, Martínez-Vallespín (2011) observó que la reducción del contenido proteico disminuyó el flujo ileal de PB, la concentración cecal de AGV totales y de $\mathrm{NH}_{3}$ 
(con aumento del $\mathrm{pH}$ ) y la mortalidad. Sin embargo, otros trabajos no detectaron diferencias en mortalidad al reducir el contenido en PB de la dieta (Xiccato et al., 2004; Trocino et al., 2013).

Gutiérrez et al. (2003) compararon dietas isoproteicas con distintas fuentes de proteína de diferente digestibilidad ileal, observando que el flujo ileal de PB, la concentración cecal de $\mathrm{NH}_{3}$ y la mortalidad fueron menores con harina de girasol, concentrado proteico de soja y harina de soja que con harina de soja + concentrado proteico de patata, sin que la fuente proteica afectara a la morfología de las vellosidades intestinales o al pH cecal. García-Palomares et al. (2006) compararon dietas de similar contenido en PB con las dos fuentes de proteína más habituales en la alimentación de los conejos, registrando una reducción del flujo ileal de PB y menor mortalidad con harina de girasol que con harina de soja; en este trabajo, la suplementación con proteasa o proteasa + xilanasa redujo el flujo ileal de PB con ambas fuentes pero la mortalidad solo en el caso de la harina de girasol, lo que sugiere un efecto negativo de los factores antinutritivos y antigénicos de la harina de soja (Carabaño et al., 2009). Trocino et al. (2010) también observaron que la mortalidad tendió a ser menor con harina de girasol que con harina de soja, sin detectar cambios en la concentración de AGV totales o de $\mathrm{NH}_{3}$ ni en el pH del ciego, como tampoco en la morfología de las vellosidades intestinales. Gutiérrez et al. (2000b) observaron que la inclusión de plasma animal sustituyendo a harina de soja mejoró la morfología de las vellosidades intestinales.

Por último, Scheele y Bolder (1987) observaron mayor mortalidad con dietas que contenían harina de soja que con dietas que contenían fuentes de proteína animal (caseína, harina de pescado y harina de carne), lo que se ha relacionado con la presencia de factores antinutritivos y antigénicos en la harina de soja (De Blas et al., 1999; Gidenne et al., 2010), aunque las dietas comparadas no eran isoproteicas (200 y $179 \mathrm{~g}$ $\mathrm{PB} / \mathrm{kg} \mathrm{MS}$, respectivamente). 

2. OBJETIVOS 

La revisión bibliográfica realizada muestra que la llegada masiva de antígenos dietarios es uno de los factores que intervienen en la problemática que se desarrolla en el destete de los animales productivos. Este hecho ha sido estudiado sobre todo en lechones y terneros, donde se ha visto que la respuesta inmunitaria frente a los antígenos dietarios y sus consecuencias varían según el origen de la proteína de la dieta, recomendándose en la práctica limitar el uso de materias primas proteicas de alta antigenicidad en la alimentación de los animales jóvenes. Sin embargo, en conejos, donde la problemática digestiva tras el destete es particularmente importante, apenas se dispone de información a este respecto.

El objetivo general del presente trabajo es conocer si en conejos, al igual que ocurre en otras especies productivas, se producen reacciones inmunitarias frente a la dieta consumida, mediante la determinación en suero sanguíneo de inmunoglobulinas IgG específicas frente a antígenos dietarios, y comparar la antigenicidad de diferentes piensos y materias primas proteicas.

Para ello es necesario el diseño y desarrollo de una técnica basada en la combinación de un método de extracción de los antígenos de piensos y materias primas proteicas con un método ELISA que valore la presencia de IgG frente a antígenos dietarios en el suero sanguíneo de conejo.

En consecuencia, los objetivos específicos son:

- Desarrollar un método de obtención de antígenos dietarios.

- Comprobar la presencia de anticuerpos IgG a frente a antígenos dietarios en el suero sanguíneo mediante Dot Immunoblotting.

- Desarrollar un ELISA indirecto para la determinación de anticuerpos IgG frente a antígenos dietarios en suero sanguíneo.

- Estudiar la antigenicidad de piensos y materias primas proteicas determinando los anticuerpos IgG frente a los antígenos dietarios en suero sanguíneo mediante el ELISA indirecto desarrollado.

- Valorar el efecto de algunas materias primas proteicas sobre ciertos parámetros histomorfológicos e inmunohistoquímicos de la mucosa intestinal. 

3. MATERIAL Y MÉTODOS 

Para abordar los objetivos planteados se realizaron 3 experimentos:

- Experimento I: se desarrolló el método de obtención de antígenos dietarios mediante hidrólisis pépsica y se comprobó mediante Dot Immunoblotting la presencia de anticuerpos IgG frente a antígenos dietarios en suero sanguíneo de conejos alimentados con dos piensos formulados para conseguir divergencia en el origen de su proteína.

- Experimento II: se desarrolló un ELISA indirecto para la determinación de IgG frente a antígenos dietarios utilizando los sueros de conejos alimentados con los piensos del Experimento I.

- Experimento III: se estudió la antigenicidad de diferentes materias primas proteicas determinando los anticuerpos IgG frente a antígenos dietarios en suero sanguíneo mediante el ELISA indirecto desarrollado en el Experimento II, así como el efecto de algunas de las materias primas proteicas sobre la histomorfología y la inmunohistoquímica de la mucosa intestinal. 


\subsubsection{ANIMALES, MANEJO Y TOMA DE MUESTRAS}

Se utilizaron dos conejas y sus camadas, de ocho gazapos cada una. Las conejas eran cruzadas de las líneas $\mathrm{V}$ y $\mathrm{A}$ (seleccionadas por tamaño de camada al destete) y habían sido inseminadas con pooles de semen de machos de la línea $\mathrm{R}$ (seleccionada por velocidad de crecimiento). Las tres líneas han sido desarrolladas en la Unidad de Mejora Genética del Departamento de Ciencia Animal de la Universidad Politécnica de Valencia.

La Figura 4 presenta un esquema del manejo de los animales y de la toma de muestras. Los gazapos se alimentaron exclusivamente con leche materna desde el nacimiento hasta los 21 días de vida, ya que desde los 14 días de vida se alojaron en jaulas de cría $\left(50 \times 70 \times 32 \mathrm{~cm}^{3}\right.$, provistas de nidales) distintas de las de sus madres, que diariamente se trasladaban a las jaulas de las camadas durante unos minutos para amamantarlas, a las 8:00-9:00 horas. A los 21 días de vida, los gazapos de cada camada fueron identificados individualmente y distribuidos aleatoriamente en dos subcamadas de cuatro gazapos, alojadas en sendas jaulas de cría, a cada una de las cuales se le asignó un pienso ( $\mathrm{A}$ ○ B), suministrado ad libitum. Desde los 21 días de vida hasta el destete (28 días de vida), las subcamadas de cada coneja se reunían antes de la lactación controlada y se volvían a separar tras la misma. Tras el destete, los gazapos se alojaron en dos jaulas de cebo $\left(50 \times 80 \times 32 \mathrm{~cm}^{3}\right)$ agrupados por el tipo de pienso asignado, que siguieron recibiendo ad libitum hasta los 56 días de vida. También tuvieron acceso libre al agua. Durante este periodo murieron nueve gazapos (cinco del Pienso A y cuatro del Pienso B), todos ellos tras mostrar síntomas y lesiones compatibles con Enteropatía Epizoótica del Conejo.

Se tomaron muestras de sangre de los gazapos y de las conejas a los 21 y 56 días de vida de los gazapos, mediante punción en la arteria central de la oreja. Se utilizaron viales estériles al vacío y sin anticoagulante, que se mantuvieron a $4^{\circ} \mathrm{C}$ durante 4 horas y se centrifugaron a 1500×G durante 10 minutos. El suero se recogió en viales Eppendorf, se identificó y se almacenó a $-80^{\circ} \mathrm{C}$ hasta su utilización.

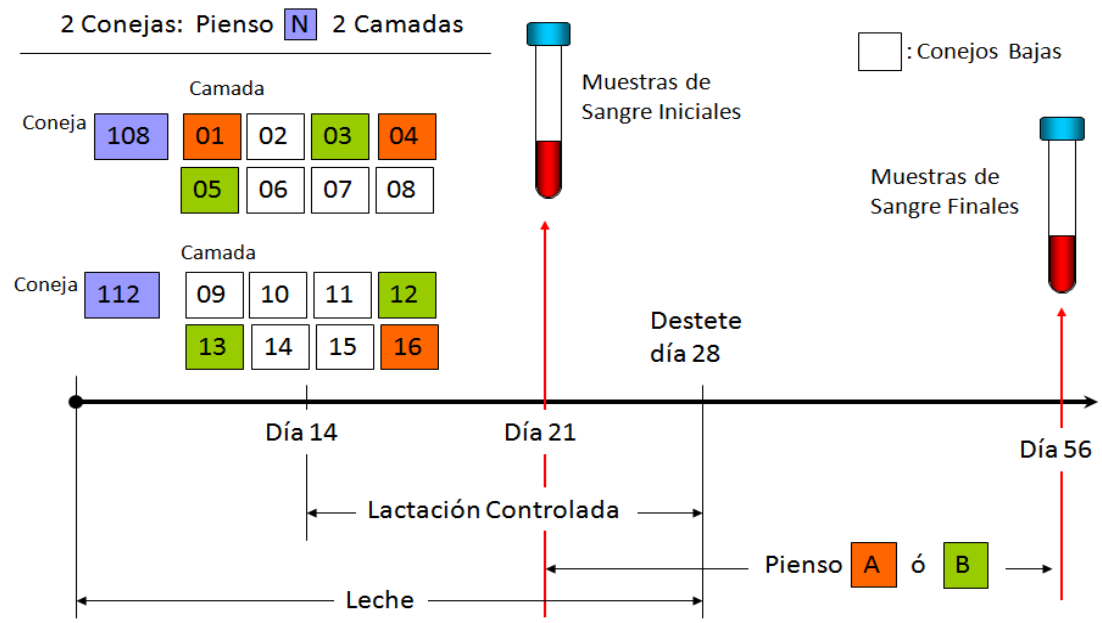

Figura 4. Esquema del manejo de los animales y de la toma de muestras en el Experimento I 


\subsubsection{EXTRACCIÓN DE ANTÍGENOS DIETARIOS}

Para extraer los antígenos dietarios se realizó una digestión incompleta de cada uno de los piensos experimentales, mediante un protocolo simplificado del método de digestión in vitro propuesto por Ramos et al. (1992). El método descrito por estos autores trata de reproducir el proceso de digestión mediante el uso secuencial de distintos enzimas. Para prevenir una excesiva digestión del pienso y la destrucción de los epítopos antigénicos de sus proteínas, el método se limitó a una digestión pépsica, que permitiera obtener hidrolizados con péptidos solubles que conservaran la antigenicidad.

Brevemente, se molieron muestras de los piensos utilizando un tamiz de $1 \mathrm{~mm}$ y se disolvieron $2 \mathrm{~g}$ de cada una en sendos matraces con $25 \mathrm{~mL}$ de tampón fosfato $0,1 \mathrm{M}$ $\mathrm{pH}=6$ y $10 \mathrm{~mL}$ de $\mathrm{HCl} 0,2 \mathrm{M}$, ajustando el $\mathrm{pH}$ a 2 con $\mathrm{HCl}$ o $\mathrm{NaOH} 1 \mathrm{M}$. Se añadió $1 \mathrm{~mL}$ de una solución de pepsina (75 mg de Pepsina A, Sigma-Aldrich, ref. P7000, en $1 \mathrm{~mL} \mathrm{de} \mathrm{HCl}$ $0,2 \mathrm{M}$ ) y se incubó durante 90 minutos a $40^{\circ} \mathrm{C}$ bajo agitación continua. Terminada la incubación, se ajustó el pH a 7 con $\mathrm{NaOH} 1 \mathrm{M}$. A continuación se centrifugó a 1500×G durante 10 minutos y se recuperó el sobrenadante pipeteando cuidadosamente, desechándose el pellet resultante de la centrifugación. Estos hidrolizados compuestos por los sobrenadantes obtenidos de cada uno de los piensos fueron homogeneizados mediante agitador vórtex, alicuotados en viales Eppendorf, etiquetados y finalmente congelados a $-80^{\circ} \mathrm{C}$ hasta su utilización.

Se obtuvo también un hidrolizado blanco mediante la aplicación del anterior protocolo sin utilizar ninguna muestra de pienso experimental. Este hidrolizado blanco se utilizó como control negativo en el inmunoensayo descrito en 3.1.4.

\subsubsection{PROTOCOLO DE DOT IMMUNOBLOTTING PARA LA DETECCIÓN DE ANTICUERPOS IgG FRENTE A ANTÍGENOS DIETARIOS EN SUERO SANGUÍNEO}

Se utilizaron membranas de nitrocelulosa (Amersham Hybond ECL, ref. RPN2020D, GE Healthcare Life Sciences) de $3 \times 3 \mathrm{~cm}^{2}$, tantas como sueros a testar, a las que se adsorbieron $20 \mu \mathrm{L}$ de los hidrolizados con la siguiente ordenación:
- Arriba - Izquierda:
Hidrolizado del Pienso A (HA)
- Arriba - Derecha:
Hidrolizado del Pienso B (HB)
- Abajo - Izquierda:
Hidrolizado del Pienso N (HN)
- Abajo - Derecha:
Control negativo

Las membranas fueron bloqueadas durante 30 minutos a temperatura ambiente con $3 \%$ de leche descremada en polvo disuelta en PBS (Sigma-Aldrich, ref. P5368) pH 7 conteniendo 0,1\% Tween 20 (Sigma-Aldrich, ref. C1379) (PBS-T).

Después de lavar tres veces con PBS-T, las membranas se incubaron durante 2 horas a $37^{\circ} \mathrm{C}$ en agitación con una dilución $1 / 10$ en PBS-T de cada uno de los sueros a testar. 
Tras desechar los sueros, las membranas se lavaron tres veces con PBS-T y se incubaron con un anticuerpo policlonal de cabra anti-IgG de conejo conjugado con peroxidasa (DAKO, ref. P0448) diluido a 1/5000 en PBS-T durante 1 hora a temperatura ambiente.

Tras desechar el anticuerpo secundario, las membranas se lavaron tres veces con PBS-T y se incubaron con la solución luminiscente (Amersham ECL Prime, ref. RPN2232, GE Healthcare Life Sciences) durante 5 minutos. Las membranas se colocaron ordenadamente entre dos láminas de acetato, eliminado el exceso de solución de la superficie y evitando la formación de burbujas. Se realizó la impresión de las placas radiográficas (Amersham Hyperfilm ECL, ref. 28906839, GE Healthcare Life Sciences) mediante contacto directo con las membranas durante 60 segundos en oscuridad y se almacenaron en casetes opacos hasta su revelado fotográfico automatizado. La intensidad de la señal emitida es proporcional a la cantidad de anticuerpos IgG presentes en el suero que se unen específicamente a las proteínas o péptidos del hidrolizado del pienso, según se representa en la Figura 5.

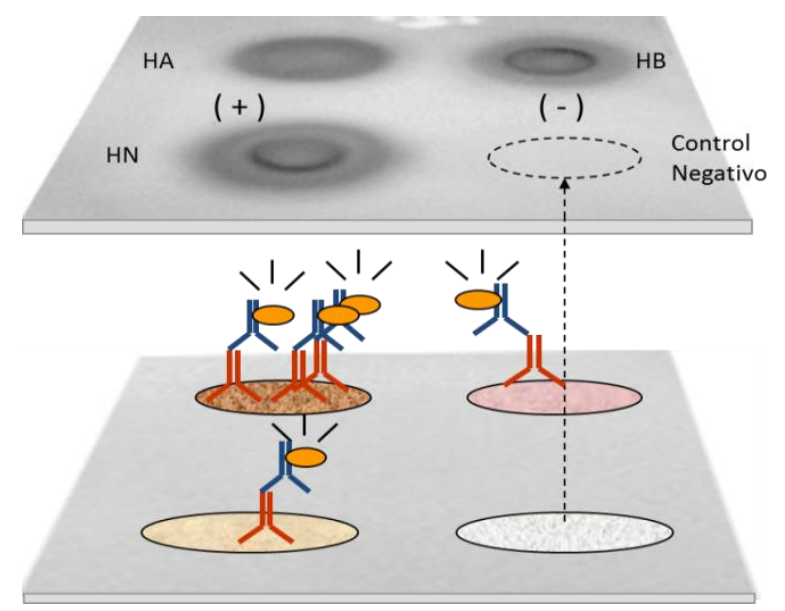

Figura 5. Dot Immunoblotting: formación y revelado del complejo antígeno-anticuerpo

La cuantificación de la intensidad de la reacción antígeno-anticuerpo en las membranas de immunoblotting se realizó mediante comparación con una escala colorimétrica de 0 a 5 compuesta por 6 tonos de gris (Tabla 2). El primero de los tonos de gris (0) coincide con el color de fondo de las membranas de immunoblotting. A mayor valor de la escala, mayor tonalidad gris y mayor intensidad de la reacción.

Tabla 2. Escala de valoración colorimétrica para las membranas de immunoblotting

\begin{tabular}{|l|l|l|}
\hline Escala & Color & \multicolumn{1}{|c|}{ Código RGB } \\
\hline 0 & & $178,178,178$ \\
\hline 1 & & $144,144,144$ \\
\hline 2 & $110,110,110$ \\
\hline 3 & $76,76,76$ \\
\hline 4 & $42,42,42$ \\
\hline 5 & $8,8,8$ \\
\hline
\end{tabular}




\subsection{EXPERIMENTO II}

\subsubsection{PIENSOS, ANIMALES, MANEJO Y TOMA DE MUESTRAS}

Se utilizaron los piensos descritos en el apartado 3.1.1 del Experimento I, con cuatro conejas y sus camadas, procediendo tal como se describe en el apartado 3.1.2 del Experimento I.

\subsubsection{EXTRACCIÓN DE ANTÍGENOS DIETARIOS}

Se realizó la obtención de los hidrolizados tal como se describe en el apartado 3.1.3 del Experimento I.

\subsubsection{MEDICIÓN DE LA PROTEÍNA DE LOS HIDROLIZADOS MEDIANTE EL MÉTODO BRADFORD}

La concentración de proteína de los hidrolizados de los piensos se valoró aplicando el protocolo descrito por el proveedor para el uso del reactivo de Bradford (Sigma-Aldrich, ref. B6916).

El análisis está basado en la reacción entre las proteínas de una solución y el colorante Azul G Brillante. El complejo proteína-colorante formado causa un cambio de absorbancia en el rango de longitudes de onda entre 465 y $595 \mathrm{~nm}$ que es directamente proporcional a la concentración de proteína.

Brevemente, se dispusieron $50 \mu \mathrm{L}$ del hidrolizado correspondiente en un tubo estéril de prolipropileno $11 \times 70 \mathrm{~mm}$ (Soria Genlab, ref. T1111E), se añadieron $1,5 \mathrm{~mL}$ de reactivo de Bradford y se homogeneizó el contenido del tubo mediante agitador vórtex. Tras 10 minutos de incubación a temperatura ambiente, la solución fue transferida a una cubeta desechable y se midió la absorbancia a $595 \mathrm{~nm}$ en un espectrofotómetro (VIS 7200, Dinko Instruments). Todas las muestras fueron procesadas por duplicado.

Para transformar los valores de absorbancia en concentraciones de proteína se obtuvo una recta patrón a partir de diluciones seriadas de BSA (Sigma-Aldrich, ref. 85040C). Las concentraciones utilizadas fueron: $0,1 \mathrm{mg} / \mathrm{mL}, 0,25 \mathrm{mg} / \mathrm{mL}, 0,50 \mathrm{mg} / \mathrm{mL}, 1 \mathrm{mg} / \mathrm{mL}$ y 1,4 $\mathrm{mg} / \mathrm{mL}$. Como diluyente se empleó el hidrolizado blanco descrito en el apartado 3.1.3. Se utilizaron alícuotas de $50 \mu \mathrm{L}$ de cada dilución de BSA tal como se ha descrito para los hidrolizados. 


\subsubsection{PROTOCOLO DE ELISA PARA VALORACIÓN DE ANTICUERPOS FRENTE A ANTÍGENOS DIETARIOS EN SUERO SANGUÍNEO}

Se diseñó un protocolo de ELISA indirecto para la determinación en suero de conejo de IgG que reconocieran específicamente antígenos dietarios obtenidos mediante hidrólisis incompleta de los piensos. Se tomó como base un protocolo genérico de ELISA indirecto (Hornbeck et al., 1991), que se fue modificando, adaptando y ajustando en cada una de sus fases, que se describen a continuación.

Tapizado:

Los hidrolizados se diluyeron con tampón bicarbonato-carbonato (Sigma-Aldrich, ref. C3041) ajustando su concentración final de proteína a 6,4 $\mu \mathrm{g} / \mathrm{mL}$. En los pocillos de la microplaca para ELISA (Costar, ref. 3590) se dispusieron $100 \mu \mathrm{L}$ de la solución anterior y se incubaron durante 24 horas a $4^{\circ} \mathrm{C}$. Después de la incubación, los pocillos se lavaron 4 veces con PBS-T.

\section{Bloqueo:}

Para evitar uniones inespecíficas, los pocillos tapizados se bloquearon usando $150 \mu \mathrm{L}$ de BSA (Sigma-Aldrich, ref. A3059-50G) diluida al 1\% en PBS e incubando 60 minutos a temperatura ambiente. Después de la incubación, los pocillos se lavaron 4 veces con PBS-T.

\section{Muestras de suero:}

Las muestras de suero, $100 \mu \mathrm{L}$ de una dilución $1 / 100$ en PBS, se dispusieron por duplicado en los pocillos correspondientes y se incubaron durante 60 minutos a temperatura ambiente. Tras desechar los sueros, los pocillos se lavaron 4 veces con PBS$\mathrm{T}$.

\section{Anticuerpo secundario:}

Como anticuerpo secundario se utilizó un anticuerpo policlonal purificado de cabra antiIgG de conejo conjugado con peroxidasa de rábano (Sigma-Aldrich, ref. A6154) diluido a 1/10000 en PBS. En cada pocillo se dispusieron $100 \mu \mathrm{L}$ de esta dilución del anticuerpo secundario, incubado durante 60 minutos a temperatura ambiente. Tras la incubación, se desechó la solución de anticuerpo secundario y los pocillos se lavaron 4 veces con PBS-T.

\section{Revelado:}

Se dispusieron $100 \mu \mathrm{L}$ de TMB (Sigma-Aldrich, ref. T0440) en cada uno de los pocillos y se incubó durante 40 minutos a temperatura ambiente y en oscuridad.

Paro:

Tras el periodo de incubación anterior, la reacción se paró mediante la adición de $100 \mu \mathrm{L}$ de $\mathrm{HCl} 1 \mathrm{~N}$. 
Lectura:

Se midió la absorbancia a $450 \mathrm{~nm}$ de cada uno de los pocillos mediante un espectrofotómetro para microplacas (ELx800, IMMCO Diagnostics).

\section{Control negativo:}

Para cada uno de los hidrolizados, se dispusieron por duplicado pocillos de control negativo, en los que se siguió el protocolo descrito pero usando $100 \mu \mathrm{L}$ de PBS en lugar de muestra de suero.

Cálculo de la absorbancia:

La absorbancia neta de cada uno de las muestras de suero frente a cada hidrolizado se calculó por diferencia entre el valor de la muestra y el del control negativo correspondiente a dicho hidrolizado.

\subsubsection{ANÁLISIS ESTADÍSTICO}

Los datos de absorbancia se analizaron mediante el procedimiento Mixed de SAS (Statistical Analysis Systems Institute, 2002).

Para el suero de las conejas se utilizó un modelo con el momento de toma de muestra (2 niveles: 21 y 56 días postparto), el hidrolizado empleado para tapizar los pocillos (2 niveles: HA y HB) y su interacción como efectos fijos y la coneja como efecto aleatorio. Para el suero inicial de los gazapos el modelo incluyó el hidrolizado empleado para tapizar los pocillos (2 niveles: HA y HB) como efecto fijo y el gazapo como efecto aleatorio. Adicionalmente, se realizaron análisis conjuntos de la absorbancia del suero de las conejas obtenido a los 21 ó 56 días postparto y del suero inicial de los gazapos utilizando modelos con el tipo de animal (2 niveles: coneja y gazapo), el hidrolizado empleado para tapizar los pocillos ( 2 niveles: HA y HB) y su interacción como efectos fijos y el individuo anidado al tipo de animal como efecto aleatorio; se tuvo en consideración la ausencia de homocedasticidad, diferenciándose que los errores de las medidas correspondientes a sueros de conejas y a sueros de gazapos eran distintos.

Para la diferencia de absorbancia entre el suero final y el suero inicial de cada gazapo se utilizó un modelo con el pienso consumido por los gazapos ( 2 niveles: $\mathrm{A}$ y B), el hidrolizado empleado para tapizar los pocillos ( 2 niveles: HA y HB) y su interacción como efectos fijos y el gazapo anidado al pienso como efecto aleatorio; se tuvo en consideración la ausencia de homocedasticidad, diferenciándose que los errores de las medidas correspondientes a sueros de gazapos enfrentados al hidrolizado del pienso que habían consumido eran distintos entre sí y del error de las restantes medidas. 


\subsection{EXPERIMENTO III}

\subsubsection{PIENSOS}

Se formularon seis piensos para conejos de cebo, de forma que la materia prima incluida como fuente principal, casi única, de proteína fuera distinta en cada uno de ellos. Tales fuentes de proteína fueron: heno de alfalfa (ALF), harina de girasol (GIR), gluten de trigo (GLU), guisante (GUI), harina de pescado (PES) y harina de soja (SOJ). También se formuló un séptimo pienso en el que todas las fuentes de proteína mencionadas contribuyeron por igual al contenido proteico del mismo (MIX). Se procuró que las dietas se ajustaran a las recomendaciones para conejos de cebo (De Blas y Mateos, 1998). Los ingredientes y la composición de los piensos se presentan en la Tabla 3.

Tabla 3. Ingredientes y composición de los piensos del Experimento III

\begin{tabular}{|c|c|c|c|c|c|c|c|}
\hline \multirow[b]{2}{*}{ Ingredientes (\%) } & ALF & GIR & GLU & GUI & PES & SOJ & MIX \\
\hline & \multirow{3}{*}{90,0} & & & & & & \multirow[b]{2}{*}{15,0} \\
\hline Heno de alfalfa & & & & & & & \\
\hline Harina de girasol & & 42,2 & & & & & 7,1 \\
\hline Gluten de trigo & & & 12,5 & & & & 2,1 \\
\hline Guisante & & & & 53,8 & & & 9,0 \\
\hline Harina de pescado & & & & & 17,8 & & 3,0 \\
\hline Harina de soja & & & & & & 23,9 & 4,0 \\
\hline Paja de cereales & & 28,0 & 52,5 & 39,6 & 51,5 & 45,7 & 34,5 \\
\hline Almidón de maíz & & 23,5 & 25,9 & & 26,1 & 22,9 & 19,0 \\
\hline Manteca & 7,50 & 2,15 & 3,25 & 2,50 & 3,00 & 3,00 & 3,00 \\
\hline L-Lisina $\mathrm{HCl}$ & 0,23 & 0,40 & 0,80 & & & 0,15 & 0,25 \\
\hline DL-Metionina & 0,22 & 0,06 & 0,20 & 0,30 & 0,20 & 0,27 & 0,21 \\
\hline L-Treonina & 0,10 & 0,20 & 0,35 & 0,25 & 0,22 & 0,25 & 0,22 \\
\hline L-Triptófano & & 0,05 & 0,15 & 0,10 & 0,10 & 0,08 & 0,07 \\
\hline Carbonato cálcico & & 1,50 & 1,70 & 1,50 & & 1,50 & 0,80 \\
\hline Fosfato monosódico & 1,35 & 1,10 & 2,00 & 1,25 & 0,35 & 1,60 & 1,20 \\
\hline Cloruro sódico & 0,10 & 0,35 & 0,15 & 0,25 & 0,20 & 0,20 & 0,25 \\
\hline Premix vit.-olig. ${ }^{1}$ & 0,50 & 0,50 & 0,50 & 0,50 & 0,50 & 0,50 & 0,50 \\
\hline \multicolumn{8}{|l|}{ Composición (g/kgMS) } \\
\hline Energía digestible $^{2}(\mathrm{MJ} / \mathrm{kg} \mathrm{MS})$ & 9,4 & 9,7 & 9,6 & 10,1 & 9,8 & 9,9 & 10,0 \\
\hline Proteína bruta ${ }^{3}$ & 149 & 140 & 143 & 133 & 133 & 140 & 136 \\
\hline Fibra neutro detergente ${ }^{4}$ & 452 & 434 & 403 & 441 & 420 & 408 & 414 \\
\hline Fibra ácido detergente ${ }^{4}$ & 300 & 252 & 212 & 208 & 217 & 215 & 227 \\
\hline Lignina ácido detergente $^{4}$ & 80 & 53 & 21 & 17 & 20 & 20 & 34 \\
\hline Almidón ${ }^{5}$ & 12 & 217 & 235 & 246 & 228 & 210 & 214 \\
\hline Lisina $^{2}$ & 8,1 & 7,9 & 8,6 & 8,2 & 8,2 & 8,6 & 8,1 \\
\hline Aminoácidos azufrados ${ }^{2}$ & 5,8 & 5,7 & 6,5 & 6,0 & 6,0 & 6,4 & 6,1 \\
\hline Treonina $^{2}$ & 6,9 & 6,7 & 7,0 & 7,1 & 7,1 & 7,3 & 6,9 \\
\hline Triptófano & 2,2 & 2,2 & 2,7 & 2,2 & 2,2 & 2,4 & 2,2 \\
\hline Calcio $^{2}$ & 15,6 & 8,8 & 8,9 & 8,2 & 12,0 & 8,6 & 9,3 \\
\hline Fósforo ${ }^{2}$ & 5,7 & 7,1 & 5,9 & 5,8 & 7,1 & 5,9 & 6,1 \\
\hline \multicolumn{8}{|c|}{$\begin{array}{l}{ }^{1} \text { Aporte por kg de pienso: Vitamina A: } 8000 \mathrm{Ul} \text {; Vitamina D: } 1500 \mathrm{UI} \text {; Vitamina E: } 25 \mathrm{mg} \text {; Vitamina K}: 1 \mathrm{mg} \text {; Vitamina B1: } \\
\text { 0,4 mg; Vitamina B2: } 2 \mathrm{mg} \text {; Ácido nicotínico: } 20 \mathrm{mg} \text {; Ácido pantoténico: } 8 \mathrm{mg} \text {; Colina: } 200 \mathrm{mg} \text {; Manganeso: } 20 \mathrm{mg} \text {; Zinc: } \\
40 \mathrm{mg} \text {; lodo: 0,5 mg; Hierro: } 30 \mathrm{mg} \text {; Cobre: } 5 \mathrm{mg} \text {; Cobalto: 0,6 mg; Selenio: 0,1 mg; Butilhidroxitolueno: 0,3 mg } \\
{ }^{2} \text { Calculado según De Blas et al. (2010) }\end{array}$} \\
\hline
\end{tabular}




\subsubsection{ANIMALES, MANEJO Y TOMA DE MUESTRAS}

Se utilizaron 35 conejas y sus camadas, con un total de 329 gazapos nacidos vivos $(9,4$ gazapos por camada). No hubo transferencia de gazapos entre camadas. Las conejas eran cruzadas de las líneas $\mathrm{V}$ y $\mathrm{A}$ (seleccionadas por tamaño de camada al destete) y habían sido inseminadas con pooles de semen de machos de la línea $R$ (seleccionada por velocidad de crecimiento). Las tres líneas han sido desarrolladas en la Unidad de Mejora Genética del Departamento de Ciencia Animal de la Universidad Politécnica de Valencia.

La Figura 6 presenta un esquema del manejo de los animales y de la toma de muestras. Los gazapos se alimentaron exclusivamente con leche materna desde el nacimiento hasta el destete, realizado a los 25 días de vida, ya que desde los 14 días de vida se

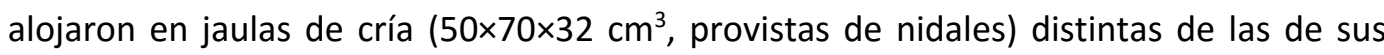
madres, que diariamente se trasladaban a las jaulas de las camadas durante unos minutos para amamantarlas, a las 8:00-9:00 horas. Durante el periodo de lactación no hubo bajas y se descartaron 21 gazapos (8\%) de bajo peso al destete considerados como mórbidos. Los 308 gazapos destetados que continuaron en la prueba se identificaron individualmente mediante tatuaje en la oreja, se asignaron de forma aleatoria a uno de los siete piensos experimentales y se alojaron en 35 jaulas de engorde $\left(50 \times 80 \times 32 \mathrm{~cm}^{3}\right)$, en grupos de 8-9 gazapos, hasta los 58 días de vida. Durante todo el periodo de cebo fueron alimentados ad libitum y tuvieron acceso libre al agua. En este periodo hubo una mortalidad del $19 \%$, en todos los casos tras síntomas y lesiones compatibles con Enteropatía Epizoótica del Conejo.

A los días 25, 29, 33, 46 y 58 de vida se registró el peso vivo de los animales (individualmente) y el consumo de pienso (por jaula). La morbilidad y la mortalidad se registraron diariamente y se utilizaron para corregir el consumo de pienso: por cada conejo mórbido detectado en un determinado periodo se descontó una ración por cada día restante del periodo y por cada animal muerto en un determinado periodo se descontaron además otras dos raciones.

Se tomaron muestras de sangre de las conejas el día del parto y de los gazapos los días 25 y 58 de vida, obtenidas y procesadas tal como se ha descrito en el apartado 3.1.2.

Se sacrificaron 10 gazapos de 29 días de vida por cada pienso, procedentes de 5 conejas distintas y elegidos al azar, mediante sobredosis de tiopental sódico inyectado por vía intracardiaca ( $75 \mathrm{mg} / \mathrm{kg}$ de peso vivo). Se tomaron muestras de unos $3 \mathrm{~cm}$ de longitud de la parte central del yeyuno, que se conservaron en botes etiquetados con formol al $10 \%$ hasta el análisis histomorfológico e inmunohistoquímico de la mucosa, para todos los piensos en el primer caso y solo para tres piensos (GLU, GUI y PES) en el segundo caso. 


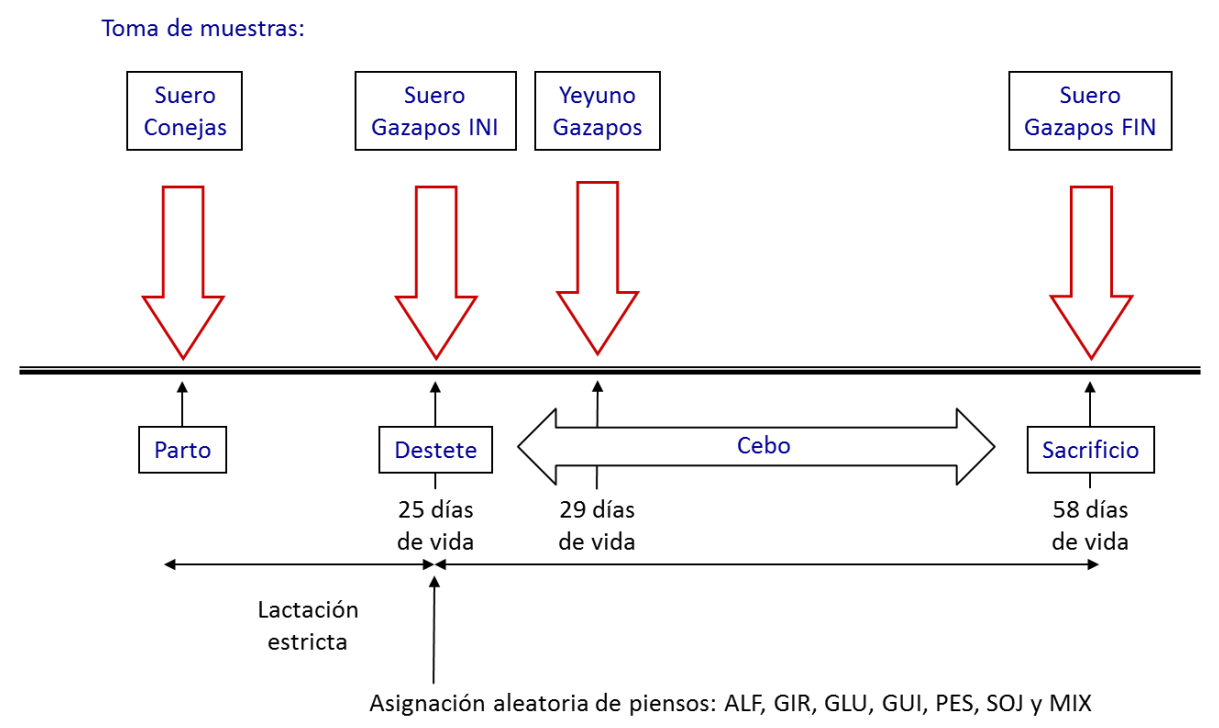

Figura 6. Esquema del manejo de los animales y de la toma de muestras del Experimento III

\subsubsection{EXTRACCIÓN DE ANTÍGENOS DIETARIOS, MEDICIÓN DE LA PROTEÍNA DE LOS HIDROLIZADOS MEDIANTE EL MÉTODO BRADFORD Y PROTOCOLO DE ELISA PARA VALORACIÓN DE ANTICUERPOS IgG FRENTE A ANTÍGENOS DIETARIOS EN SUERO SANGUÍNEO}

Para la extracción de los antígenos dietarios se procedió tal como se ha descrito en el Experimento I (apartado 3.1.3), pero en este caso a partir de cada una de las seis materias primas utilizadas como fuentes de proteína en la formulación de los piensos experimentales.

La medición de la proteína de los hidrolizados mediante el método Bradford se realizó como se ha indicado en el apartado 3.2.3. La valoración de los anticuerpos frente a antígenos dietarios en los sueros sanguíneos se realizó mediante ELISA según se ha detallado en el apartado 3.2.4 con la diferencia de que el anticuerpo secundario en este caso se diluyó a $1 / 20000$.

Para que las condiciones analíticas fueran lo más homogéneas posible, el suero inicial y el suero final de un mismo gazapo se analizaron en la misma placa. Además se utilizó un suero de referencia en todas las placas como control interno para detectar posibles variaciones en los resultados por causas metodológicas e instrumentales. Este suero de referencia se constituyó como un pool con $100 \mu \mathrm{L}$ de los sueros finales de dos conejos de cada uno de los piensos, se alicuotó en viales Eppendorf y se congeló a $-80^{\circ} \mathrm{C}$ hasta su uso. 


\subsubsection{ANÁLISIS HISTOMORFOLÓGICO DE LA MUCOSA YEYUNAL}

\subsubsection{PREPARACIÓN DE LAS MUESTRAS}

Para valorar la histomorfología de la mucosa, las muestras de yeyuno fijadas en formol se procesaron con arreglo al protocolo histológico que se describe a continuación.

Tallado:

De cada una de las muestras se cortaron 4 secciones transversales e independientes, que se dispusieron en casetes histológicos.

Deshidratación e inclusión en bloques de parafina:

Los casetes histológicos con las secciones de las muestras se sometieron a un proceso de deshidratación gradual con una concentración creciente de alcohol etílico (50-100\%) en un procesador de tejidos (Citadel 2000, Thermo Scientific), seguido de inclusión en parafina en una estación de embebido (Shandon Histocentre 2, Thermo Scientific).

Corte histológico:

Los bloques de parafina se desbastaron y se cortaron utilizando un micrótomo giratorio (Shandon Hypercut, Thermo Scientific), para obtener cortes de 3-4 $\mu \mathrm{m}$ de espesor, que se expandieron en agua caliente, se dispusieron sobre portaobjetos y se secaron en estufa a $60^{\circ} \mathrm{C}$ durante 20 minutos.

Tinción con hematoxilina-eosina:

Las preparaciones se dispusieron en cestillas histológicas y se realizó una tinción con hematoxilina-eosina según el siguiente protocolo: xilol (I): 10 minutos; xilol (II): 10 minutos; etanol-100 (I): 5 minutos; etanol- $100^{\circ}$ (II): 5 minutos; etanol- $96^{\circ}$ (I): 5 minutos; etanol-96 (II): 5 minutos; agua destilada: 5 minutos; hematoxilina: 5 minutos; agua destilada: 5 minutos; eosina: 1 minuto; agua destilada: 5 minutos; etanol-96 $6^{\circ}$ (I): 5 minutos; etanol- $96^{\circ}$ (II): 5 minutos; etanol- $100^{\circ}$ (I): 5 minutos; etanol-100 (II): 5 minutos.

Montaje de las preparaciones:

El montaje de la preparaciones se realizó sumergiéndolas secuencialmente en dos cubetas de xilol durante 3 segundos, poniendo una gota de medio de montaje (Cytoseal 60, Richard-Allan Scientific), colocando el cubreobjetos y dejando secar la preparación horizontalmente a temperatura ambiente. Una vez secas, las preparaciones fueron etiquetadas y almacenadas hasta la medición de la altura de las vellosidades y la profundidad de las criptas de Lieberkühn. 


\subsubsection{MEDICIÓN DE LA ALTURA DE LAS VELLOSIDADES Y LA PROFUNDIDAD DE LAS CRIPTAS DE LIEBERKÜHN}

Se utilizó un microscopio óptico (Eclipse ME-600, Nikon) con un objetivo de $\times 10$, provisto de cámara fotográfica digital y software de captura de imagen (DN100, Nikon), para obtener archivos tipo JPG con un tamaño de 1028×960 pixeles, una resolución de 96 puntos por pulgada y una profundidad de color de 24 bits. Para las mediciones en las imágenes de los cortes histológicos se utilizó el software ImageJ (Rasband, W.S., ImageJ, U. S. National Institute of Health, Bethesda, Maryland, USA, http://imagej.nih.gov/ij/, 1997-2014), calibrado con un portaobjetos con graduación micrométrica fotografiado con el equipo y la calidad de imagen descritos anteriormente.

Cada preparación histológica contenía 4 cortes yeyunales, cada uno de los cuales se dividió en 4 cuadrantes. En cada uno de ellos se midió la distancia entre el ápice y la muscular de la mucosa de dos vellosidades que estuvieran íntegras y cortadas perpendicularmente y la profundidad de las criptas contiguas. La altura de la vellosidad se calculó como la diferencia entre estas dos distancias, como ilustra la Figura 7. De esta forma, se midió la altura de 32 vellosidades y la profundidad de 32 criptas en cada muestra.

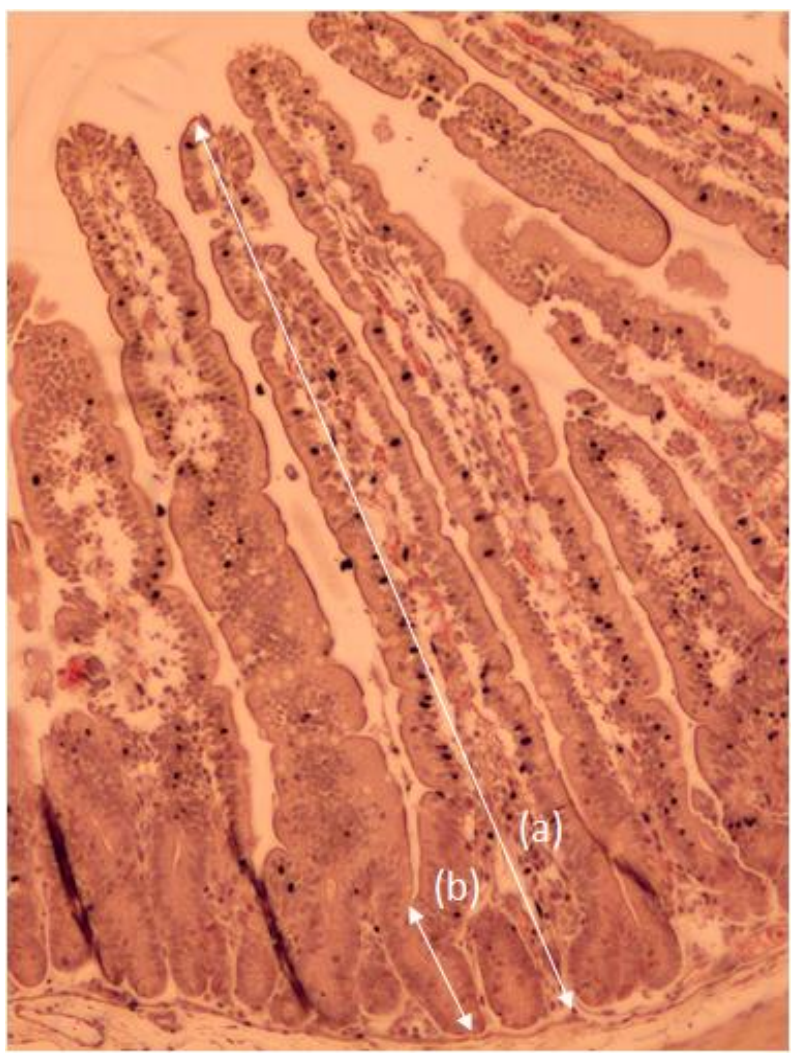

Figura 7. Fotografía del corte histológico de yeyuno de unas de las muestras procesadas mostrando las mediciones realizadas de la altura de las vellosidades (a-b) y la profundidad de las criptas (b) 


\subsubsection{ANÁLISIS INMUNOHISTOQUÍMICO DE LA MUCOSA YEYUNAL}

Se tomó como base el protocolo el descrito por Viana (2009) para el tejido mamario de conejas, adaptándolo al tejido intestinal con el objetivo de cuantificar el número de linfocitos T en las vellosidades y el número de células en división en las criptas.

\subsubsection{PREPARACIÓN DE LAS MUESTRAS}

El proceso de tallado, inclusión en bloques de parafina y corte histológico se realizó como se ha descrito en el apartado 3.3.4.1, aunque en este caso los cortes depositados sobre los portaobjetos se mantuvieron en estufa a $37^{\circ} \mathrm{C}$ durante una hora.

Hidratación de la muestra:

Las preparaciones se dispusieron en cestillas histológicas y se hidrataron según el siguiente protocolo: xilol (I), 10 minutos; xilol (II), 10 minutos; etanol- $100^{\circ}$ (I), 5 minutos; etanol- $100^{\circ}$ (II), 5 minutos; etanol- $96^{\circ}, 5$ minutos; agua destilada, 5 minutos.

Pretratamiento de la muestra con calor en tampón citrato:

Las muestras se sumergieron en tampón citrato y se dispusieron en la cámara Decloaker (Biocare Medical) 20 minutos a $125^{\circ} \mathrm{C}$. Cuando la presión de la cámara había bajado, las muestras se sacaron y se dejaron enfriar unos 20 minutos. Se lavó a temperatura ambiente con agua destilada durante 5 minutos 2 veces y con tampón tris- $\mathrm{HCl}$ salino $(0,05 \mathrm{M}$ de trizma base y $0,5 \mathrm{M}$ de $\mathrm{ClNa}$; $\mathrm{pH} 7,36)$ con $0,1 \%$ Tween20 (TBS-T) durante 5 minutos 2 veces.

Bloqueo de la peroxidasa endógena:

Las muestras se sumergieron en la solución de bloqueo de la peroxidasa endógena durante 15 minutos a temperatura ambiente. Se lavó con agua destilada durante 5 minutos 2 veces y luego con TBS-T durante 5 minutos 2 veces. Solución de bloqueo de la peroxidasa endógena: $100 \mathrm{~mL}$ de metanol extra puro (NF Scharlau) con 1,5 mL de agua oxigenada al $30 \%$.

\section{Delimitación:}

Con un rotulador indeleble-impermeable se delimitó la zona a tratar abarcando las 4 secciones fijadas al portaobjetos, para contener los anticuerpos y reactivos depositados sobre las muestras y evitar pérdidas.

Bloqueo:

Se añadieron $200 \mu \mathrm{L}$ de la solución de bloqueo. Se incubó en una estufa a $37^{\circ} \mathrm{C}$ durante 10 minutos. Solución de bloqueo: $10 \mathrm{~mL}$ de TBS-albúmina + 3 gotas de suero de caballo (ABC Kit pk-6102, Atom). TBS-albúmina: tampón tris-HCl salino con 3\% de BSA. 


\section{Anticuerpo primario:}

Se añadieron $150 \mu \mathrm{L}$ del anticuerpo primario en solución con TBS-albúmina. En el control negativo solo se añadió TBS-albúmina.

Para marcar linfocitos $\mathrm{T}$ se utilizó un anticuerpo monoclonal anti-CD3 de conejo obtenido en rata (Peter F. Moore, Universidad de California en Davis) en una dilución $1 / 5$. Como control positivo se utilizó una muestra de ganglio linfático de conejo adulto. Para marcar células en división se utilizó un anticuerpo monoclonal anti-ki67 de conejo obtenido en ratón (Menarin, ref. 29351) en una dilución 1/15. Como control positivo se utilizó una muestra de yeyuno de conejo adulto.

Se incubó toda la noche en nevera a $5^{\circ} \mathrm{C}$, con humedad y en oscuridad. Tras la incubación se lavó a temperatura ambiente con agua destilada durante 5 minutos 2 veces y luego con TBS-T durante 5 minutos 2 veces.

\section{Anticuerpo secundario:}

Se añadieron $150 \mu \mathrm{L}$ del anticuerpo secundario en solución con TBS-albúmina.

Como anticuerpo secundario del anti-CD3 se utilizó un anticuerpo anti-IgG de rata biotinilado obtenido en cabra (BA-9400, Vector), en una dilución 1/400.

Como anticuerpo secundario del anti-ki67 se utilizó un anticuerpo anti-lgG de ratón biotinilado obtenido en caballo (ABC Kit pk-6102, Atom), diluido añadiendo una gota en $10 \mathrm{~mL}$ de TBS-albúmina y 3 gotas de suero de caballo.

Se incubó en estufa a $37^{\circ} \mathrm{C}$ durante 30 minutos. Tras la incubación se lavó a temperatura ambiente con agua destilada durante 5 minutos 2 veces y luego con TBS-T durante 5 minutos 2 veces.

\section{Estreptavidina y avidina-biotina:}

Para marcar linfocitos $\mathrm{T}$ se añadieron $200 \mu \mathrm{L}$ de estreptavidina-peroxidasa (SigmaAldrich, ref. S-2438) en una dilución 1/500 en TBS-albúmina.

Para marcar células en división se añadieron $200 \mu \mathrm{L}$ de avidina-biotina-peroxidasa, preparada media hora antes de su utilización, con 2,5 $\mathrm{mL}$ de TBS-albúmina, 1 gota de $A$ (avidina) y 1 gota de B (peroxidasa de rábano biotinilada) (ABC Kit pk-6102, Atom).

Se incubó en estufa a $37^{\circ} \mathrm{C}$ durante 30 minutos. Tras la incubación se lavó a temperatura ambiente con agua destilada durante 5 minutos 2 veces y luego con TBS-T durante 5 minutos 2 veces.

\section{Revelado:}

Se añadieron $200 \mu \mathrm{L}$ de solución de revelado o solución substrato para la peroxidasa: 5 $\mathrm{mL}$ de agua destilada, con 2 gotas de tampón, 4 gotas de diaminobenzidina (DAB) y 2 gotas de solución de agua oxigenada (Kit DAB, SK-4100, Vector). Debe prepararse una hora antes de su uso, removiendo cada vez que se añaden unas gotas. Se incubó durante 2 minutos para los linfocitos $T$ y durante 5 minutos para las células en división. Se lavó con agua corriente durante 5 minutos, introduciendo la cestilla con los portas en un recipiente y dejando correr el agua en el grifo. 


\section{Tinción de contraste:}

Para contrastar las preparaciones, se tiñó durante 1 minuto con hematoxilina de Harry (Diapath) diluida 1/3 en agua destilada. Se lavó con agua corriente durante 5 minutos, introduciendo la cestilla con los portas en un recipiente y dejando correr el agua en el grifo.

Montaje de las preparaciones:

Se realizó como se ha indicado en el apartado 3.3.4.1.

\subsubsection{RECUENTOS CELULARES}

Las muestras se observaron al microscopio óptico (Eclipse ME-600, Nikon), con objetivos de $\times 20$ para linfocitos $T$ en las vellosidades y $\times 40$ para células en división en las criptas, provisto de cámara fotográfica digital y software de captura de imagen (DN100, Nikon), para obtener archivos tipo JPG con un tamaño de 1028×960 pixeles, una resolución de 96 puntos por pulgada y una profundidad de color de 24 bits.

En el caso de los linfocitos $T$ se hicieron recuentos en 10 vellosidades íntegras y cortadas perpendicularmente, para obtener el número de linfocitos T por vellosidad (Figura 8, a). En el caso de las células en división se hicieron recuentos en 10 criptas contiguas a vellosidades íntegras cortadas perpendicularmente, contándose el número de células en división y de células no proliferantes incluidas en un campo circular de $75 \mu \mathrm{m}$ de diámetro (Figura 8, b).

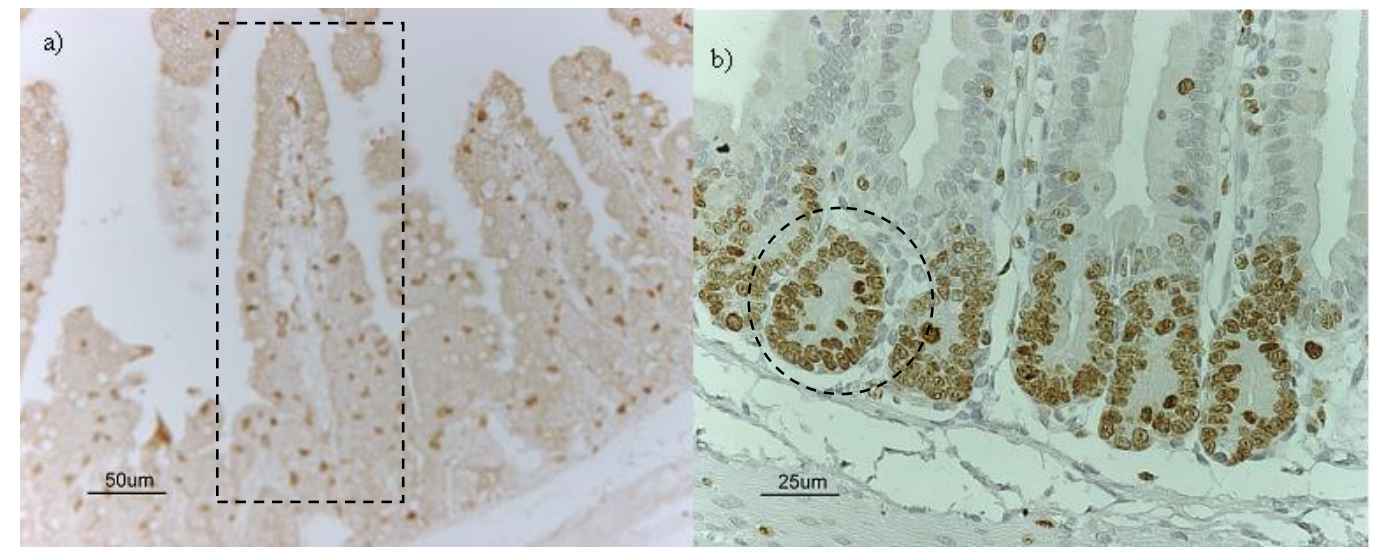

Figura 8. Fotografías para el recuento de linfocitos T en vellosidades (a) y de células en división en criptas (b) 


\subsubsection{ANÁLISIS ESTADÍSTICO}

Los resultados obtenidos se analizaron utilizando el paquete de software estadístico SAS (Statistical Analysis Systems Institute, 2002).

Para estimar la repetibilidad entre placas, la absorbancia del control negativo y del suero de referencia se analizó mediante el procedimiento GLM, utilizando un modelo con el hidrolizado empleado para tapizar los pocillos (6 niveles: HALF, HGIR, HGLU, HGUI, HPES y HSOJ) como efecto principal.

La absorbancia de los sueros se analizó mediante el procedimiento Mixed. Para el suero de las conejas y el suero inicial de los gazapos se utilizó un modelo con el tipo de animal (2 niveles: coneja y gazapo), el hidrolizado empleado para tapizar los pocillos (6 niveles: HALF, HGIR, HGLU, HGUI, HPES y HSOJ) y su interacción como efectos fijos y el individuo anidado al tipo de animal como efecto aleatorio; se tuvo en consideración la ausencia de homocedasticidad, diferenciándose que los errores de las medidas correspondientes a sueros de conejas y a sueros de gazapos eran distintos. Para la diferencia de absorbancia entre el suero final y el suero inicial de cada gazapo se utilizó un modelo con el pienso consumido por los gazapos (7 niveles: ALF, GIR, GLU, GUI, PES, SOJ y MIX), el hidrolizado empleado para tapizar los pocillos (6 niveles: HALF, HGIR, HGLU, HGUI, HPES y HSOJ) y su interacción como efectos fijos y el gazapo anidado al pienso como efecto aleatorio; se tuvo en consideración la ausencia de homocedasticidad, diferenciándose que los errores de las medidas correspondientes a sueros de gazapos enfrentados al hidrolizado del pienso que habían consumido eran distintos entre sí y del error de las restantes medidas.

Los datos obtenidos en el análisis histomorfológico e inmunohistoquímico de la mucosa yeyunal y los rendimientos productivos se analizaron mediante el procedimiento GLM, utilizando un modelo con el pienso consumido por los gazapos (7 niveles: ALF, GIR, GLU, GUI, PES, SOJ y MIX, en los parámetros histomorfológicos y rendimientos productivos; 3 niveles: GLU, GUI y PES, en los parámetros inmunohistoquímicos) como efecto principal. Además, los parámetros histomorfológicos e inmunohistoquímicos obtenidos con los piensos GLU, GUI y PES se analizaron con el procedimiento Corr para estimar las correlaciones lineales simples y parciales entre ellos. 

4. RESULTADOS 



\subsection{EXPERIMENTO I}

La Figura 9 muestra las membranas de immunoblotting obtenidas al enfrentar los sueros de los gazapos y las conejas con los hidrolizados de los piensos. La disposición de los hidrolizados en cada una de las membranas es la siguiente: HA (superior-izquierda), HB (superior-derecha) y HN (inferior-izquierda). El cuadrante inferior-derecha corresponde al control negativo.

a) Dot Immunoblottings de los sueros de los gazapos
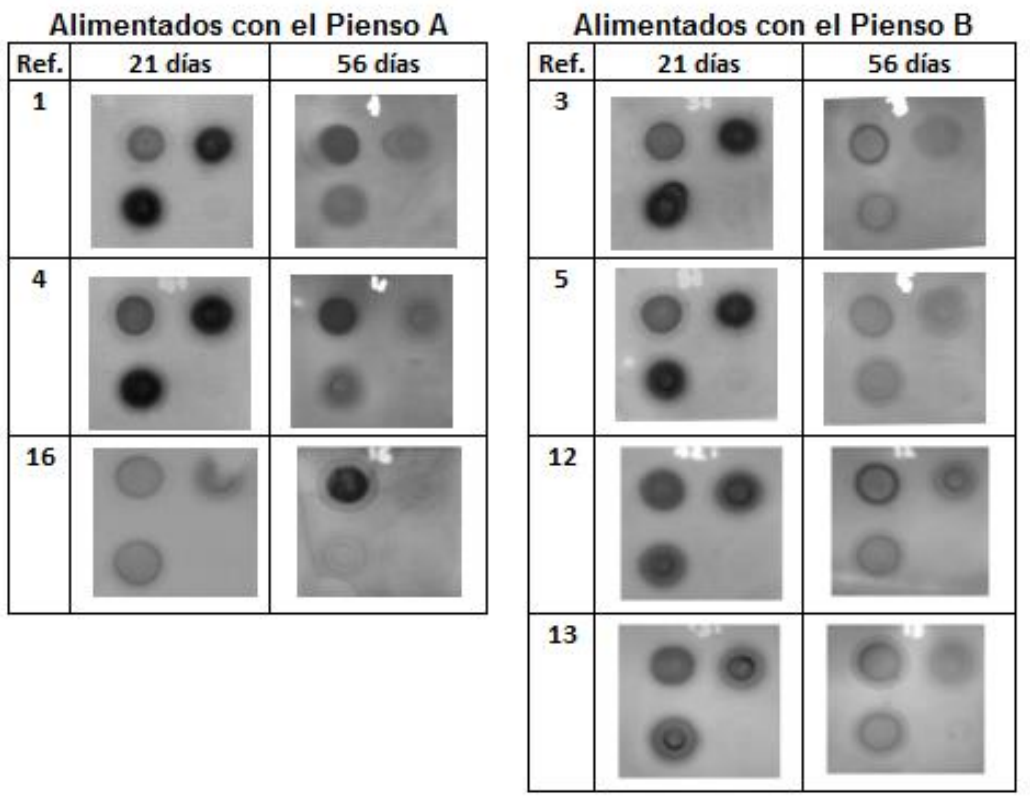

b) Dot Immunoblottings de los sueros de las conejas alimentadas con el Pienso $\mathrm{N}$

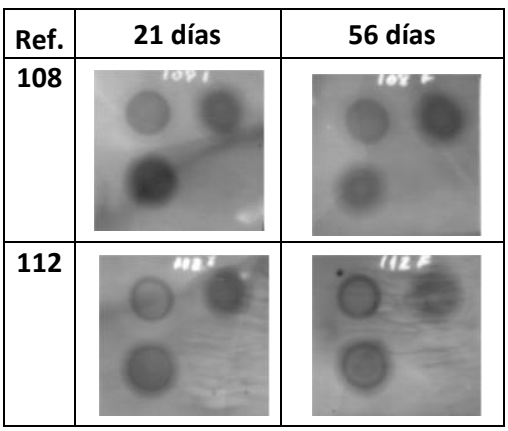

Figura 9. Membranas de Dot Immunoblotting de sueros de gazapos obtenidos a los 21 y 56 días de vida agrupados por el pienso que consumieron durante ese periodo (a) y de sueros de las conejas madres a los 21 y 56 días postparto (b)

La intensidad de la tonalidad gris de los distintos círculos observados en las membranas es indicativa de la cantidad de IgG que reconocen antígenos presentes en los hidrolizados de los piensos, que se valoró con una escala colorimétrica de 0 a 5 descrita en el apartado 3.1.4. 
Los sueros analizados, tanto de los gazapos como de sus madres, no presentaron reactividad frente al control negativo. Este hecho es indicativo de la ausencia de uniones inespecíficas de lgG séricas con componentes del tampón o de la solución pépsica utilizados para la extracción de los antígenos dietarios.

La Tabla 4 muestra que en todos los sueros de las conejas, obtenidos a los 21 y 56 días postparto, se evidenció reactividad indicativa de la presencia de IgG frente a proteínas contenidas en los hidrolizados de los tres piensos.

Tabla 4. Valoración según escala colorimétrica de la reactividad en immunoblotting de los sueros de conejas a los 21 y 56 días postparto frente a los hidrolizados de los Piensos A, B y N (HA, HB y HC, respectivamente; C: control negativo)

\begin{tabular}{|c|c|c|c|c|c|c|c|c|}
\hline \multirow[b]{2}{*}{ Coneja } & \multicolumn{4}{|c|}{21 días postparto } & \multicolumn{4}{|c|}{56 días postparto } \\
\hline & $\mathrm{HA}$ & $\mathrm{HB}$ & $\mathrm{HN}$ & C & $\mathrm{HA}$ & $\mathrm{HB}$ & $\mathrm{HN}$ & C \\
\hline 108 & 1 & 2 & 4 & 0 & 1 & 3 & 1 & 0 \\
\hline 112 & 1 & 3 & 2 & 0 & 2 & 3 & 2 & 0 \\
\hline
\end{tabular}

En la Tabla 5 se observa que los sueros de los gazapos a los 21 días de edad, cuando todavía eran estrictamente lactantes, mostraron en general niveles de reactividad elevados indicativos de la presencia de IgG frente a proteínas contenidas en los hidrolizados de los tres piensos, menos evidentes en uno de los siete casos (gazapo 16).

Tabla 5. Valoración según escala colorimétrica de la reactividad en immunoblotting de los sueros de gazapos a los 21 y 56 días de vida frente a los hidrolizados de los piensos A, B y N (HA, HB y $\mathrm{HC}$, respectivamente; $\mathrm{C}$ : control negativo) en función del pienso consumido durante ese periodo

\begin{tabular}{|c|c|c|c|c|c|c|c|c|c|c|}
\hline \multirow[b]{2}{*}{ Gazapo } & \multirow[b]{2}{*}{ Coneja } & \multirow[b]{2}{*}{ Pienso } & \multicolumn{4}{|c|}{21 días de vida } & \multicolumn{4}{|c|}{56 días de vida } \\
\hline & & & $\mathrm{HA}$ & $\mathrm{HB}$ & $\mathrm{HN}$ & $\mathrm{C}$ & $\mathrm{HA}$ & $\mathrm{HB}$ & $\mathrm{HN}$ & C \\
\hline 1 & 108 & $A$ & 2 & 5 & 5 & 0 & 3 & 1 & 2 & 0 \\
\hline 4 & 108 & $A$ & 3 & 5 & 5 & 0 & 3 & 1 & 2 & 0 \\
\hline 16 & 112 & $A$ & 1 & 1 & 1 & 0 & 4 & 0 & 0 & 0 \\
\hline 3 & 108 & $B$ & 2 & 5 & 4 & 0 & 2 & 1 & 1 & 0 \\
\hline 5 & 108 & B & 2 & 4 & 4 & 0 & 1 & 1 & 1 & 0 \\
\hline 12 & 112 & B & 3 & 4 & 3 & 0 & 2 & 1 & 1 & 0 \\
\hline \multirow[t]{3}{*}{13} & 112 & $\mathrm{~B}$ & 2 & 3 & 3 & 0 & 1 & 1 & 1 & 0 \\
\hline & \multicolumn{2}{|c|}{ Promedio Pienso A } & 2,0 & 3,7 & 3,7 & 0 & 3,3 & 0,7 & 1,3 & 0 \\
\hline & \multicolumn{2}{|c|}{ Promedio Pienso B } & 2,3 & 4,0 & 3,5 & 0 & 1,5 & 1,0 & 1,0 & 0 \\
\hline
\end{tabular}

Por otro lado, la evolución de esta reactividad entre los 21 y los 56 días de vida fue distinta dependiendo del pienso consumido por los gazapos durante ese periodo y del hidrolizado al que se enfrentaron los sueros, como se ilustra en la Figura 10. Así, dos de los tres gazapos que consumieron el Pienso A mostraron un aumento de la reactividad frente al hidrolizado del Pienso A mientras que la reactividad frente a los hidrolizados de los piensos no consumidos por los gazapos ( $\mathrm{B}$ y N) disminuyó en los tres casos. Por el contrario, los cuatro gazapos que consumieron el Pienso B presentaron un descenso de la reactividad frente al hidrolizado tanto del Pienso $\mathrm{B}$ como de los piensos no 
consumidos por los gazapos ( $\mathrm{A}$ y $\mathrm{N}$ ), salvo en el caso del gazapo 3 , que no varió su nivel de reactividad frente al Pienso $A$.

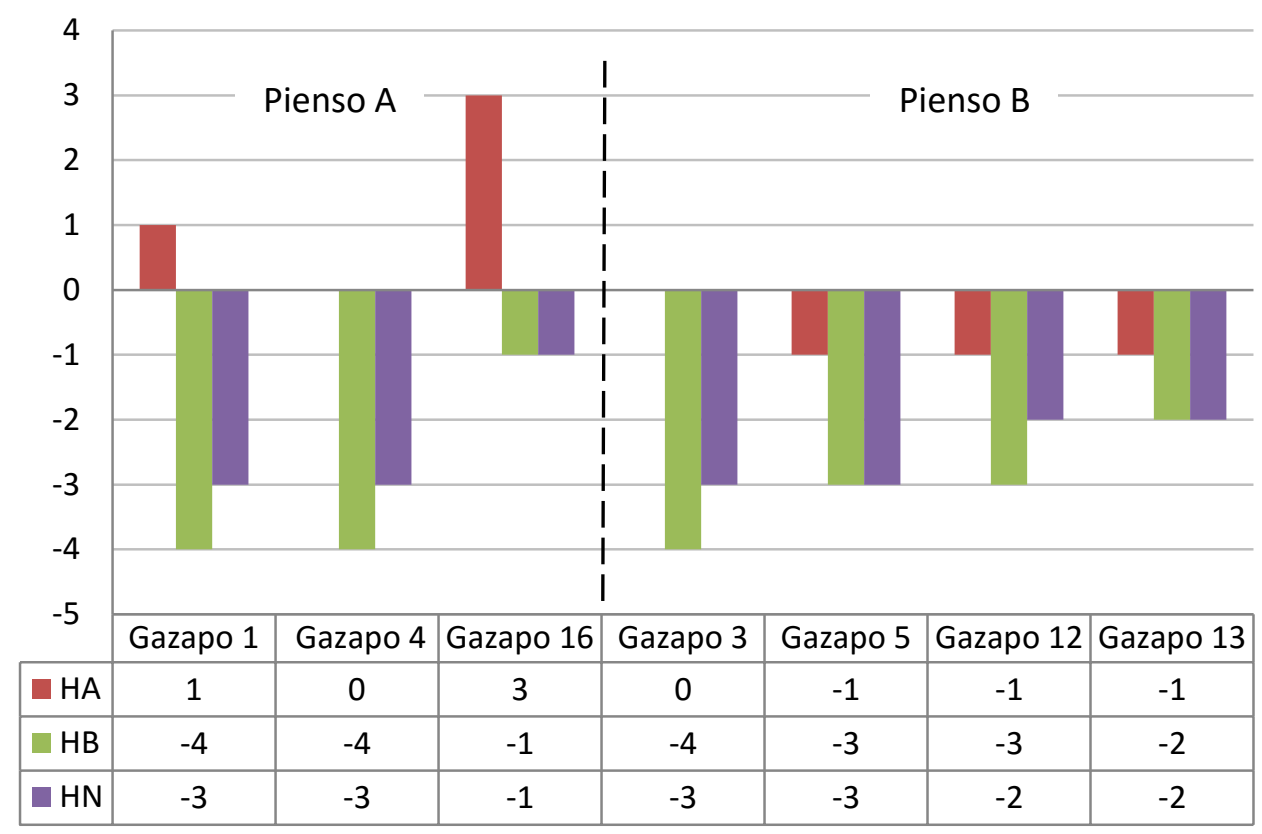

Figura 10. Cambio de la valoración según escala colorimétrica de la reactividad en immunoblotting de los sueros de gazapos entre los 21 y 56 días de vida frente a los hidrolizados de los piensos $A, B$ y N (HA, HB y HC, respectivamente) en función del pienso consumido durante ese periodo 


\subsection{EXPERIMENTO II}

\subsubsection{PUESTA A PUNTO DEL ELISA INDIRECTO PARA LA VALORACIÓN DE ANTICUERPOS IgG FRENTE A ANTÍGENOS DIETARIOS EN SUERO SANGUÍNEO}

\subsubsection{AJUSTE DE LA CONCENTRACIÓN DE PROTEÍNA DE LOS HIDROLIZADOS}

Se sabe que la concentración de proteína de la solución de tapizado repercute en la adsorción de proteínas en las paredes de los pocillos de las placas ELISA y puede variar la intensidad de la reacción antígeno-anticuerpo, influyendo en los resultados del ELISA. Para evitar esta interferencia, se determinó la concentración de proteína de los hidrolizados de cada pienso y las diluciones con la que se tapizaron los pocillos de las placas ELISA se estandarizaron a la misma concentración final de proteína. Como la concentración de proteína fue de 0,44 y $0,64 \mathrm{mg} / \mathrm{mL}$ en $\mathrm{HA}$ y HB , los hidrolizados se diluyeron a $1 / 68$ y $1 / 100$, respectivamente, con el tampón de tapizado bicarbonatocarbonato, para obtener una concentración final de proteína de $6,4 \mu \mathrm{g} / \mathrm{mL}$, que está dentro de las recomendaciones para los protocolos ELISA.

\subsubsection{AJUSTE DE LA CONCENTRACIÓN DE LOS SUEROS}

Para determinar la dilución óptima de los sueros problema, se analizó un suero final de un conejo alimentado con el Pienso $A$ (Suero A) y un suero final de un conejo alimentado con el Pienso B (Suero B) en pocillos tapizados con HA y HB, cuya concentración de proteína se ajustó a $6,4 \mu \mathrm{g} / \mathrm{mL}$ según se ha descrito en el apartado anterior. Se testaron diluciones seriadas de los sueros desde $1 / 5$ a $1 / 5120$ y se dispuso un control negativo con PBS. El anticuerpo secundario se utilizó a dos diluciones con PBS: 1/5000 y 1/10000.

La Tabla 6 recoge la absorbancia registrada. Cuando la absorbancia superó la capacidad de medida del espectrofotómetro ( $\geq 3$ ) se asignó el valor out.

Tabla 6. Absorbancia a $450 \mathrm{~nm}$ de distintas diluciones de sueros problemas (A y $B$ ) enfrentados a los hidrolizados $\mathrm{HA}$ y $\mathrm{HB}$, con dos concentraciones de anticuerpo secundario (out indica un valor $\geq 3$, fuera del rango del espectrofotómetro)

\begin{tabular}{cccccccccccccccc}
\hline \multirow{2}{*}{$\begin{array}{c}\text { Antígeno } \\
\text { Tapizado }\end{array}$} & Suero & Secundario & & C- & $1 / 5120$ & $1 / 2560$ & $1 / 1280$ & $1 / 640$ & $1 / 320$ & $1 / 160$ & $1 / 80$ & $1 / 40$ & $1 / 20$ & $1 / 10$ & $1 / 5$ \\
\cline { 5 - 14 } & HA & A & $1 / 5000$ & 0,206 & 0,711 & 1,024 & 1,331 & 1,776 & 2,202 & 2,763 & out & out & out & out & out \\
HA & B & $1 / 5000$ & 0,174 & 0,283 & 0,306 & 0,388 & 0,486 & 0,692 & 0,985 & 1,305 & 1,785 & 2,589 & out & out \\
HB & A & $1 / 5000$ & 0,100 & 0,286 & 0,308 & 0,325 & 0,482 & 0,664 & 1,006 & 1,378 & 1,934 & 2,701 & out & out \\
HB & B & $1 / 5000$ & 0,074 & 0,196 & 0,231 & 0,244 & 0,349 & 0,484 & 0,705 & 0,975 & 1,346 & 1,924 & 2,521 & 2,839 \\
HA & A & $1 / 10000$ & 0,139 & 0,533 & 0,698 & 0,863 & 1,111 & 1,403 & 1,743 & 2,010 & 2,455 & 2,904 & out & out \\
HA & B & $1 / 10000$ & 0,132 & 0,218 & 0,230 & 0,253 & 0,330 & 0,426 & 0,586 & 0,787 & 1,064 & 1,506 & 1,860 & 2,368 \\
HB & A & $1 / 10000$ & 0,108 & 0,188 & 0,204 & 0,218 & 0,302 & 0,407 & 0,591 & 0,800 & 1,135 & 1,512 & 2,015 & 2,267 \\
HB & B & $1 / 10000$ & 0,092 & 0,162 & 0,165 & 0,166 & 0,214 & 0,307 & 0,442 & 0,550 & 0,781 & 1,271 & 1,589 & 1,998
\end{tabular}


Independientemente del hidrolizado utilizado para el tapizado de los pocillos y de la dilución utilizada del anticuerpo secundario, la absorbancia correspondiente al control negativo fue muy baja, entre 0,074 y 0,206 , sensiblemente menor que la correspondiente a pocillos que incorporaban las distintas diluciones de los sueros testados. Estos resultados evidencian un bajo nivel de reacciones inespecíficas entre el anticuerpo secundario y otras moléculas presentes en los pocillos, como las procedentes de los hidrolizados dietarios y la BSA utilizada para cubrir posibles zonas descubiertas, lo que indica un correcto protocolo de tapizado y bloqueo de los pocillos. Puede observarse que se obtuvieron valores fuera de rango cuando se enfrentaron concentraciones de $1 / 80$ o superiores del Suero A con HA y el anticuerpo secundario se utilizó con una dilución 1/5000. Entre las restantes combinaciones también se observaron algunos valores fuera de rango cuando se utilizaron concentraciones de 1/10 ó $1 / 5$.

Con los resultados obtenidos se puede concluir que es recomendable utilizar una dilución $1 / 100$ de los sueros problema y la dilución $1 / 10000$ del anticuerpo secundario, como se ilustra en la Figura 11, ya que con ello se reduce el riesgo de obtener valores fuera de rango y se diferencia la absorbancia obtenida al enfrentar el Suero $A$ con $H A$ de la obtenida en las restantes combinaciones (Suero B-HA, Suero A-HB y Suero B-HB), en concordancia con los resultados obtenidos mediante Dot Immunoblotting presentados en el apartado 4.1.

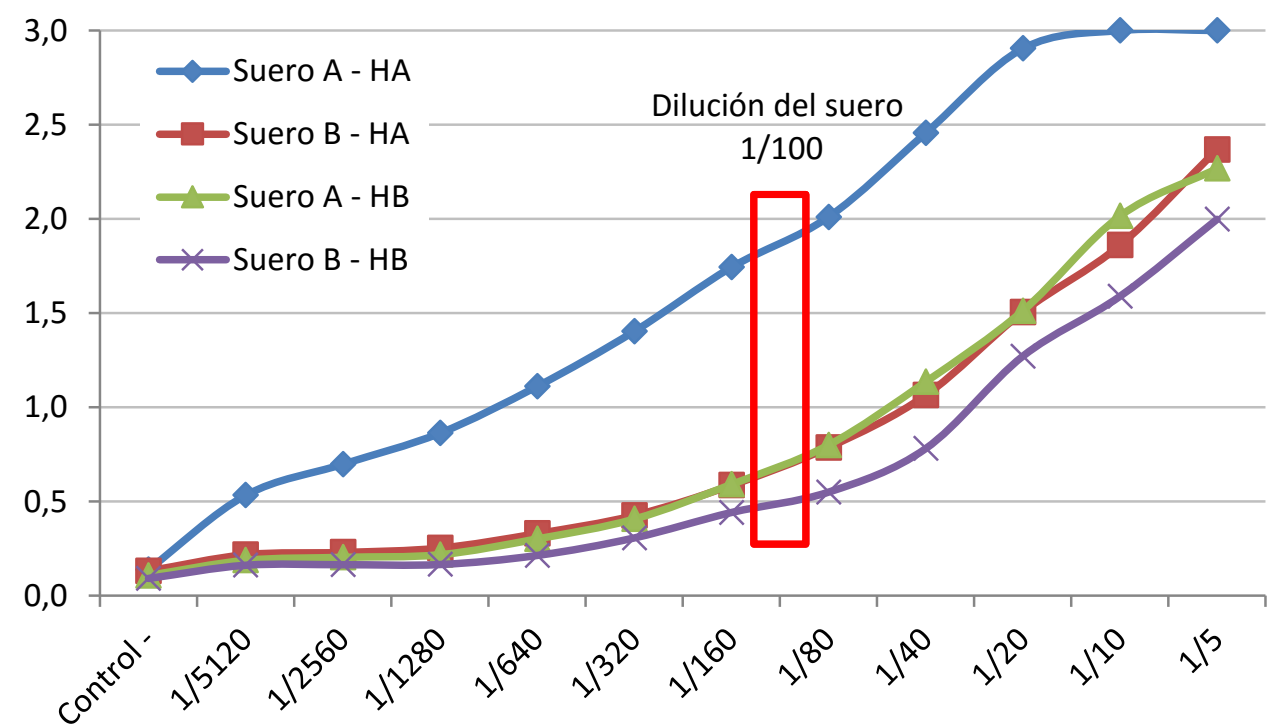

Figura 11. Absorbancia a $450 \mathrm{~nm}$ de distintas diluciones de sueros problemas (A y $B$ ) enfrentados a los hidrolizados HA y HB, utilizando la dilución 1/10000 del anticuerpo secundario 


\subsubsection{AJUSTE DE LA CONCENTRACIÓN DEL ANTICUERPO SECUNDARIO}

Las muestras analizadas fueron los sueros inicial y final de un conejo que había consumido el Pienso A (Sueros A) y de un conejo que había consumido el Pienso B (Sueros B), así como el suero de una de las cuatro conejas. Los sueros se diluyeron a $1 / 100$ con PBS, según los resultados obtenidos en el apartado anterior. Como control negativo se utilizó PBS. Las muestras se enfrentaron en duplicado con pocillos tapizados con hidrolizados de ambos piensos, ajustando su concentración de proteína a $6,4 \mathrm{\mu g} / \mathrm{ml}$ según se ha descrito en el apartado 4.2.1.1. Se testaron diferentes diluciones del anticuerpo secundario en PBS: $1 / 100000,1 / 50000,1 / 10000$ y $1 / 5000$.

\begin{tabular}{|c|c|c|c|c|c|c|c|}
\hline Antígeno & $\begin{array}{l}\text { Anticuerpo } \\
\text { Secundario }\end{array}$ & $\begin{array}{c}\text { SUERO A } \\
\text { Inicial }\end{array}$ & $\begin{array}{c}\text { SUERO B } \\
\text { Inicial }\end{array}$ & $\begin{array}{c}\text { SUERO A } \\
\text { Final }\end{array}$ & $\begin{array}{c}\text { SUERO B } \\
\text { Final }\end{array}$ & $\begin{array}{l}\text { SUERO } \\
\text { Coneja }\end{array}$ & $\begin{array}{l}\text { CONTROL } \\
\text { Negativo }\end{array}$ \\
\hline \multirow{4}{*}{ HA } & $1 / 100000$ & 6 & & & & & \\
\hline & $1 / 50000$ & 4 & & & & & \\
\hline & $1 / 10000$ & i. & & & & & \\
\hline & $1 / 5000$ & c. & & & & & \\
\hline \multirow{4}{*}{$\mathrm{HB}$} & $1 / 100000$ & \& & & & & & \\
\hline & $1 / 50000$ & 8 & $e^{2}$ & $y$ & 8 & & \\
\hline & $1 / 10000$ & & & & & & \\
\hline & $1 / 5000$ & & & & & & \\
\hline
\end{tabular}

Figura 12. Fotografía y esquema de la placa ELISA utilizada para testar diferentes diluciones del anticuerpo secundario

Los resultados se presentan en la Figura 12 y la Figura 13. Como puede verse, la concentración de anticuerpo secundario no tuvo efecto sobre los valores de absorbancia obtenidos con el control negativo, que se mantuvieron muy bajos en todos los casos, indicando la baja cantidad de uniones inespecífica del anticuerpo secundario con los hidrolizados adsorbidos en los pocillos y la proteína de bloqueo.

Por el contrario, la concentración de anticuerpo secundario tuvo una gran influencia en la absorbancia obtenida con las muestras de sueros. Diluciones $1 / 100000$ y $1 / 50000$ del anticuerpo secundario produjeron valores de absorbancia muy bajos, cercanos al control negativo, indicando que no hay suficiente anticuerpo secundario para unirse a todas las IgG que forman complejos con los antígenos dietarios presentes en los hidrolizados. Esta limitación es más evidente en los sueros con una mayor cantidad de IgG frente a antígenos dietarios, como sería el caso de los sueros finales de los gazapos. Si además consideramos que el riesgo de obtener valores de absorbancia fuera de rango es mayor con la dilución $1 / 5000$, la dilución del anticuerpo secundario más recomendable es la $1 / 10000$. 
a) Hidrolizado $A$

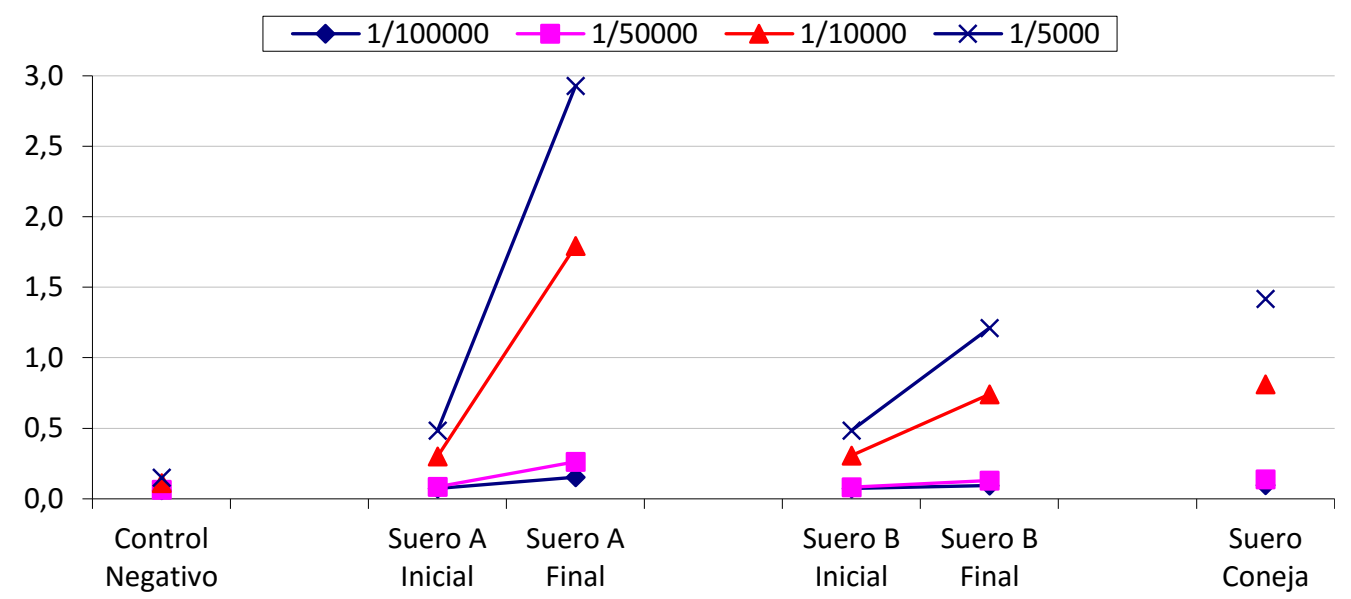

b) Hidrolizado B

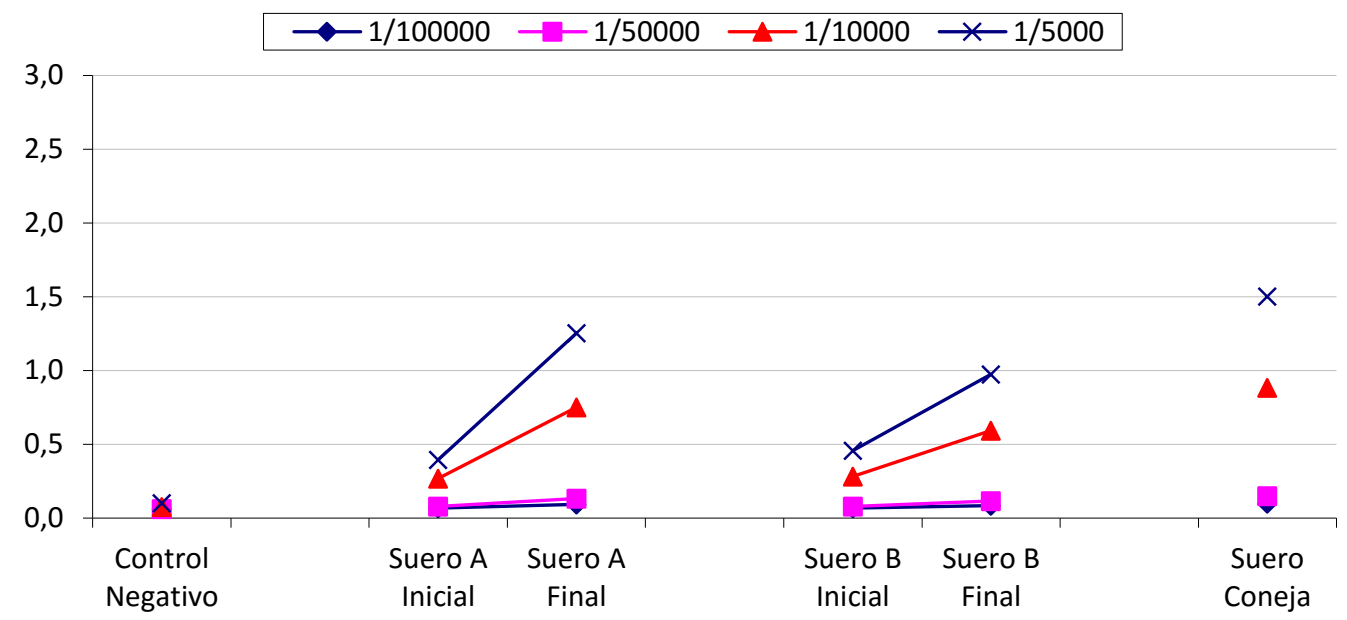

Figura 13. Absorbancia a $450 \mathrm{~nm}$ de diferentes sueros diluidos $1 / 100$ utilizando distintas diluciones del anticuerpo secundario: a) tapizado con hidrolizado $H A$, b) tapizado con hidrolizado HB

\subsubsection{AJUSTE DEL TIEMPO DE INCUBACIÓN CON TMB}

Para estudiar el efecto del tiempo de incubación del TMB con el complejo formado por antígeno + anticuerpo primario + anticuerpo secundario conjugado con peroxidasa, se tapizó una placa con HA ajustando su concentración de proteína a $6,4 \mu \mathrm{g} / \mathrm{mL}$ según se ha descrito en el apartado 4.2.1.1.

Se utilizó el suero final de un conejo alimentado con el Pienso $A$ (Suero $A$ ) en diluciones seriadas en PBS: $1 / 25,1 / 50,1 / 100,1 / 200,1 / 400,1 / 800$ y $1 / 1600$, así como un control negativo (PBS). El anticuerpo secundario se utilizó a una dilución $1 / 10000$ con PBS. 
Se registró la absorbancia a $620 \mathrm{~nm}$ transcurridos 5, 10, 15, 20, 30, 35, 40 y 60 minutos después de añadir TMB. Los resultados se muestran en la Figura 14. Como podemos ver, el principal incremento de absorbancia a $620 \mathrm{~nm}$ se produce en los primeros 20 minutos de incubación, la curva de absorbancia se aplana a partir de los 30 minutos y la máxima absorbancia se obtiene a los 40 minutos, observándose una muy ligera pérdida de absorbancia a partir de entonces. En consecuencia, se establece que la incubación con TMB para el revelado del inmunocomplejo sea de 40 minutos.

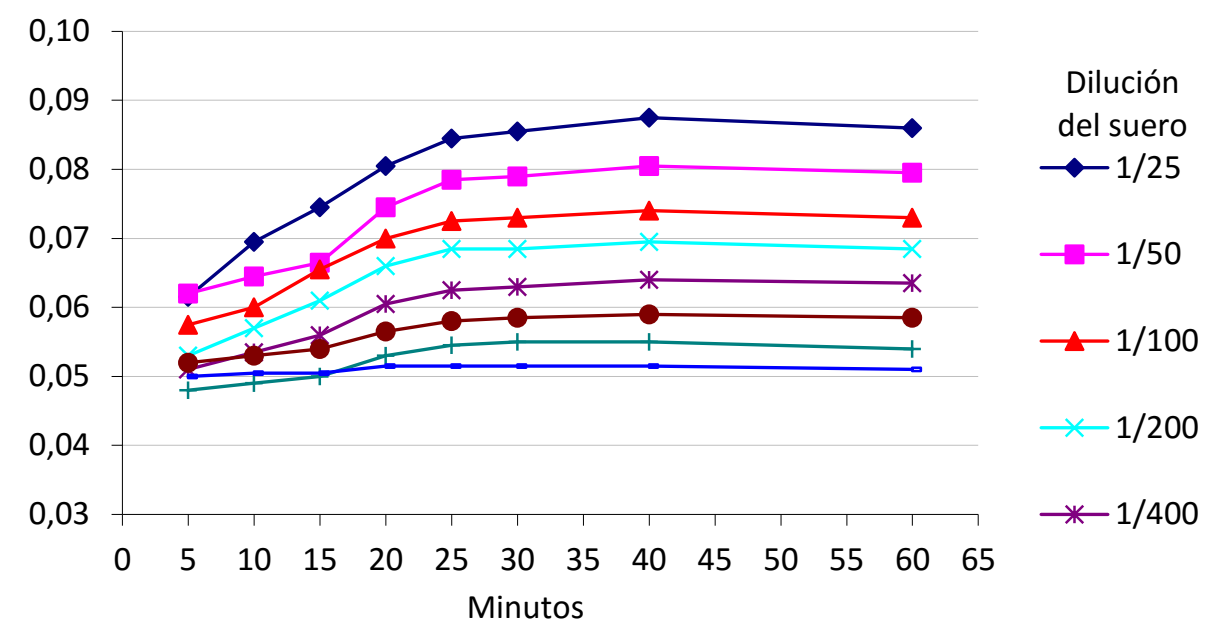

Figura 14. Efecto del tiempo de incubación con TMB sobre la absorbancia a $620 \mathrm{~nm}$ con diferentes diluciones de suero final de conejo alimentado con el Pienso A enfrentado a un hidrolizado HA

\subsubsection{ABSORBANCIA A $620 \mathrm{~nm}$ VERSUS ABSORBANCIA A $450 \mathrm{~nm}$}

La placa ELISA utilizada para el ajuste de la concentración del anticuerpo secundario (apartado 4.2.1.3) se leyó a $620 \mathrm{~nm}$ al finalizar la incubación de 40 minutos con TMB y también a $450 \mathrm{~nm}$ tras parar la reacción añadiendo $100 \mu \mathrm{L}$ de $\mathrm{HCl} 1 \mathrm{~N}$ a cada pocillo y provocar un cambio de color, tal como se ilustra en la Figura 15.

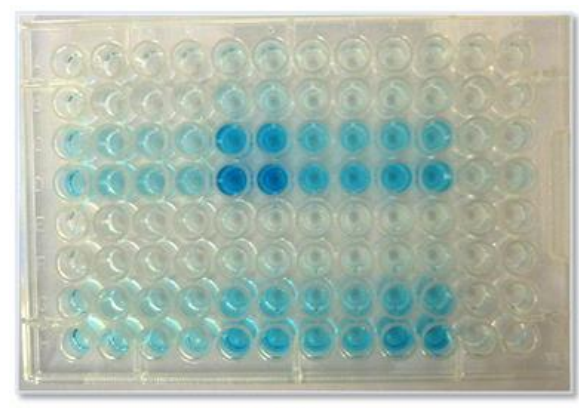

(a)

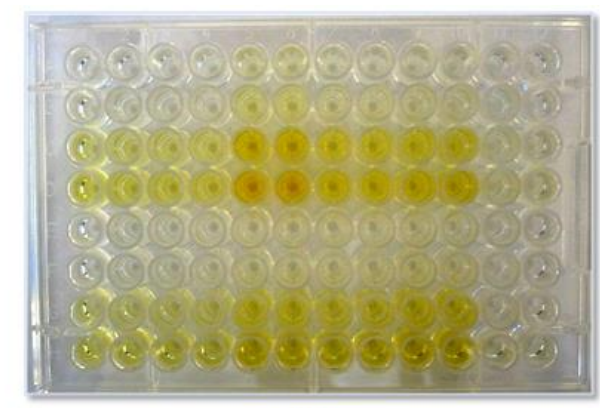

(b)

Figura 15. Revelado del inmunocomplejo: (a) tras 40 minutos de incubación con $\mathrm{TMB}$, (b) con posterior adición de $100 \mu \mathrm{L}$ de $\mathrm{HCl} 1 \mathrm{~N}$ 
La Figura 16 muestra la estrecha correlación lineal existente entre la absorbancia medida a $450 \mathrm{~nm}$ y $620 \mathrm{~nm}$. Se decidió medir la absorbancia a $450 \mathrm{~nm}$, ya que es estable durante 60 minutos, lo que permitió trabajar con varias placas ELISA simultáneamente con menos error que en el caso de medir a $620 \mathrm{~nm}$ sin parar la reacción con $\mathrm{HCl}$.

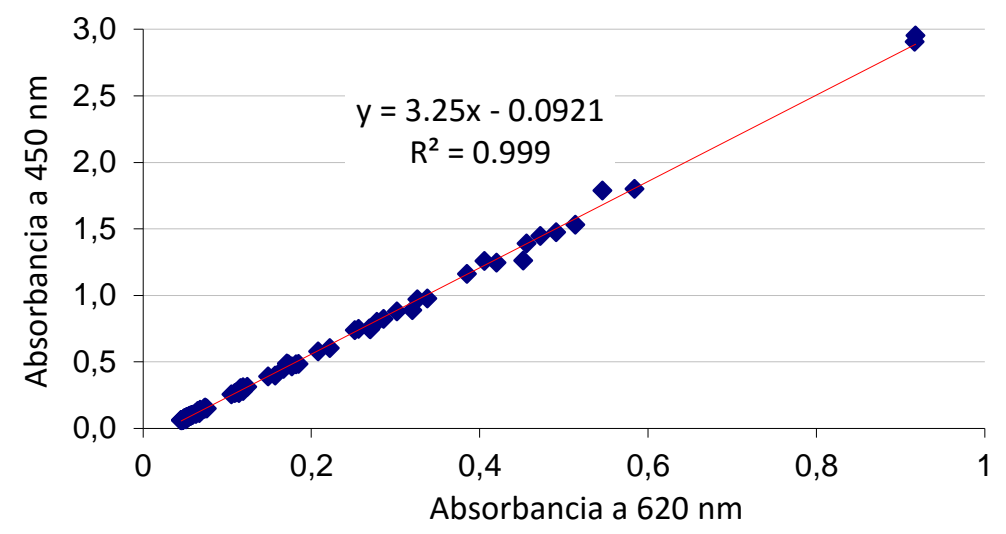

Figura 16. Regresión de la absorbancia a $450 \mathrm{~nm}$ tras 40 minutos de incubación con TMB y paro con $\mathrm{HCl} 1 \mathrm{~N}$ sobre la absorbancia a $620 \mathrm{~nm}$ tras 40 minutos de incubación con TMB

\subsubsection{ANTICUERPOS FRENTE A ANTÍGENOS DIETARIOS EN SUERO SANGUÍNEO DE GAZAPOS ALIMENTADOS CON LOS PIENSOS EXPERIMENTALES Y SUS MADRES}

Los sueros iniciales y finales de 15 gazapos ( 9 alimentados con el Pienso A y 6 alimentados con el Pienso B) y de sus 4 madres (alimentadas con el pienso $\mathrm{N}$ ) se procesaron por duplicado en 2 placas ELISA, ambas con pocillos tapizados con HA ० HB, según el protocolo descrito en el apartado 3.2.4 junto con controles negativos (PBS). La absorbancia a $450 \mathrm{~nm}$ en los controles negativos fue baja en las 2 placas ELISA procesadas $(0,060$ y 0,0580 con $\mathrm{HA}, 0,0560$ y 0,0580 con $\mathrm{HB})$, lo que confirma el bajo nivel de reacciones inespecíficas del protocolo utilizado.

\subsubsection{SUEROS DE LAS CONEJAS}

La absorbancia de los sueros de las conejas se presenta en la Tabla 7. Los valores fueron similares en los dos momentos de toma de muestras ( 21 ó 56 días postparto) y tampoco fue significativa la diferencia en función del hidrolizado utilizado para el tapizado de los pocillos, debida a que una de las conejas presentó valores sensiblemente más altos que las restantes cuando los sueros se enfrentaron a HB $(1,4558$ vs. 0,3385$)$ pero no cuando se enfrentaron a HA $(0,4298$ vs. 0,2707$)$.

Tabla 7. Absorbancia a $450 \mathrm{~nm}$ de los sueros de las conejas en función del momento de toma de la muestra y el hidrolizado utilizado para el tapizado de los pocillos (MMC, $n=4$ )

\begin{tabular}{|c|c|c|c|c|c|c|c|}
\hline \multicolumn{2}{|c|}{ Toma de muestra } & \multicolumn{2}{|c|}{ Hidrolizado } & \multirow[b]{2}{*}{ EEM } & \multirow[b]{2}{*}{$P_{T M}$} & \multirow[b]{2}{*}{$P_{H}$} & \multirow[b]{2}{*}{$P_{T M^{*} H}$} \\
\hline $21 \mathrm{dpp}$ & $56 \mathrm{dpp}$ & $\mathrm{HA}$ & $\mathrm{HB}$ & & & & \\
\hline 0,442 & 0,486 & 0,311 & 0,618 & 0,182 & 0,795 & 0,091 & 0,987 \\
\hline
\end{tabular}

dpp: días postparto; MMC: Media ajustada por Mínimos Cuadrados; EEM: Error Estándar de las Medias 


\subsubsection{SUEROS DE LOS GAZAPOS}

La absorbancia de los sueros iniciales de los gazapos ( 21 días de vida) se muestra en la Tabla 8. Los valores obtenidos fueron similares con los dos hidrolizados utilizados para el tapizado de los pocillos. A su vez, estos valores fueron menores que los observados en los sueros de las conejas obtenidos a los 21 días postparto $(-0,358 \pm 0,152 ; P=0,031)$ o a los 56 días postparto $(-0,402 \pm 0,178 ; P=0,038)$.

Tabla 8. Absorbancia a $450 \mathrm{~nm}$ de los sueros iniciales de los gazapos (21 días de vida) en función del hidrolizado utilizado para el tapizado de los pocillos (MMC, $n=15$ )

\begin{tabular}{|c|c|c|c|}
\hline \multicolumn{2}{|c|}{ Hidrolizado } & \multirow[b]{2}{*}{ EEM } & \multirow[b]{2}{*}{$P$} \\
\hline $\mathrm{HA}$ & $\mathrm{HB}$ & & \\
\hline 0,073 & 0,095 & 0,017 & 0,366 \\
\hline
\end{tabular}

Al analizar el incremento de absorbancia entre los sueros inicial (21 días de vida) y final (56 días de vida) de cada gazapo no se encontraron diferencias significativas asociadas al pienso ingerido por los gazapos durante tal periodo o al hidrolizado utilizado para el tapizado de los pocillos, pero sí una interacción significativa entre ambos factores $(P=0,003)$, ilustrada en la Figura 17. El incremento de absorbancia fue mayor en los sueros de los gazapos que habían consumido el Pienso $A$ enfrentados a pocillos tapizados con HA que en los restantes casos, es decir, sueros de gazapos que habían ingerido el Pienso $B$ enfrentados a pocillos tapizados con HB o sueros de gazapos enfrentados con pocillos tapizados con el pienso que no habían consumido.

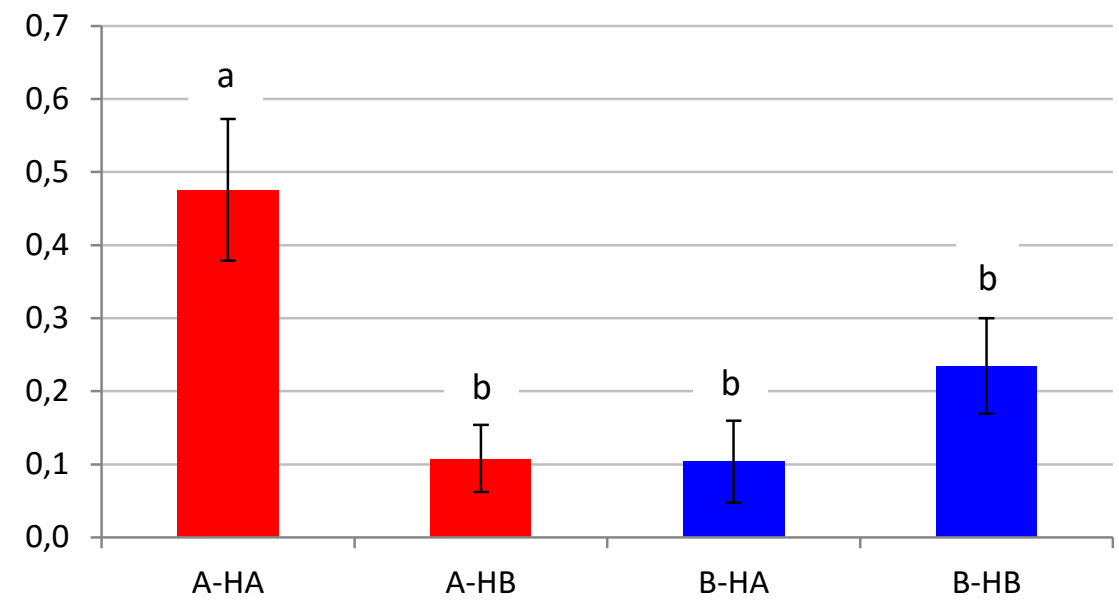

Figura 17. Aumento de absorbancia a $450 \mathrm{~nm}$ en los sueros de los gazapos entre los 21 y los 56 días de vida en función del pienso consumido (A, B) y el hidrolizado utilizado para tapizar los pocillos (HA, HB). Media ajustada por Mínimos Cuadrados \pm Error Estándar de la Media $(A: n=9 ; B: n=6)$. Letras distintas indican diferencias significativas con $P<0,05$ 


\subsection{EXPERIMENTO III}

\subsubsection{CONCENTRACIÓN PROTEICA DE LOS HIDROLIZADOS PÉPSICOS DE LAS FUENTES DE PROTEÍNA DIETARIA}

Para cada una de las materias primas proteicas objeto de estudio se realizó una digestión pépsica y una valoración de la concentración proteica del hidrolizado resultante, según se ha descrito en los apartados 3.1.3 y 3.2.3, respectivamente. También se incluyó la paja porque entraba en un alto porcentaje en la composición de todos los piensos experimentales, salvo en el basado en heno de alfalfa, para comprobar en qué grado podía contribuir al contenido proteico de los hidrolizados y provocar reacciones cruzadas entre los piensos.

Los resultados se muestran en la Figura 18. El máximo contenido proteico se observó en el hidrolizado de la harina de soja $(0,925 \mathrm{mg} / \mathrm{mL})$ y el mínimo en la harina de pescado $(0,185 \mathrm{mg} / \mathrm{mL})$. El hidrolizado de paja presentó valores ligeramente negativos (-0,045 $\mathrm{mg} / \mathrm{mL}$ ), lo que indica la nula contribución de la paja al contenido proteico de los hidrolizados de los piensos experimentales.

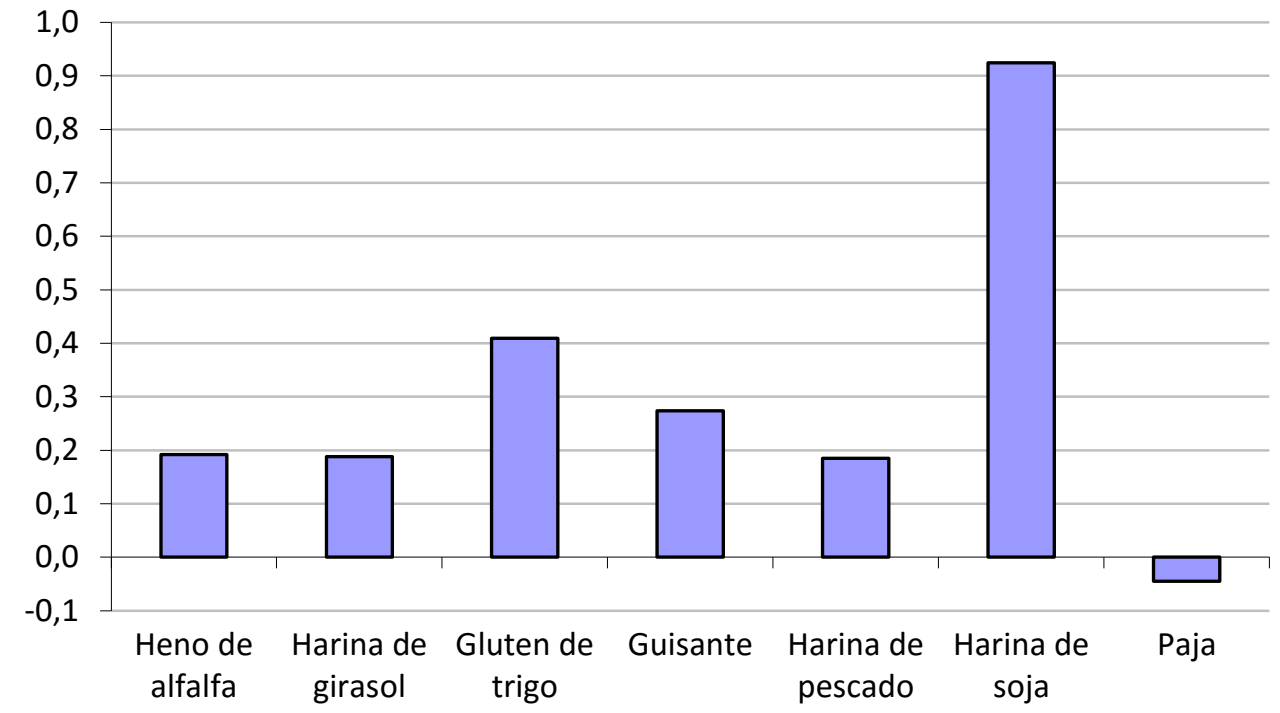

Figura 18. Concentración de proteína de los hidrolizados de las materias primas $(\mathrm{mg} / \mathrm{mL})$

Los hidrolizados de heno de alfalfa (HALF), harina de girasol (HGIR), gluten de trigo (HGLU), guisante (HGUI), harina de pescado (HPES) y harina de soja (HSOJ) se diluyeron a $1 / 30,1 / 29,1 / 64,1 / 43,1 / 29$ y $1 / 145$, respectivamente, con el tampón de tapizado bicarbonato-carbonato, para obtener una concentración final de proteína de $6,4 \mu \mathrm{g} / \mathrm{mL}$. 


\subsubsection{AJUSTE DEL PROTOCOLO ELISA}

Se utilizaron diferentes diluciones de un suero de coneja $(1 / 25,1 / 50,1 / 100,1 / 200$, $1 / 400,1 / 800$ y $1 / 1600$ ) y un control negativo (sin suero), enfrentados a los hidrolizados de las seis materias primas estudiadas El anticuerpo secundario se diluyó a 1/10000, 1/20000, 1/50000 y 1/100000. Los resultados se presentan en la Figura 19.

En todos los casos, la absorbancia del control negativo fue muy baja, lo que indica la ausencia de reacciones inespecíficas.

Las diluciones $1 / 100000$ y $1 / 50000$ de anticuerpo secundario dieron lugar a bajos valores de absorbancia, con poca capacidad para discriminar entre las diferentes diluciones del suero, lo que indica escasez de anticuerpo secundario para reaccionar con todas las IgG del suero que reconocen antígenos presentes en los hidrolizados de las materias primas y forman inmunocomplejos.

Los valores de absorbancia obtenidos con una dilución del anticuerpo secundario a $1 / 10000$ fueron muy altos, con mediciones fuera de rango para diluciones del suero a $1 / 25,1 / 50$ y hasta $1 / 100$, dependiendo del hidrolizado empleado.

Los valores de absorbancia obtenidos con la dilución 1/20000 del anticuerpo secundario estuvieron dentro de rango de medición y permitieron discriminar entre las diferentes diluciones del suero, por lo que en el protocolo ELISA del Experimento III se estableció esta concentración de anticuerpo secundario.

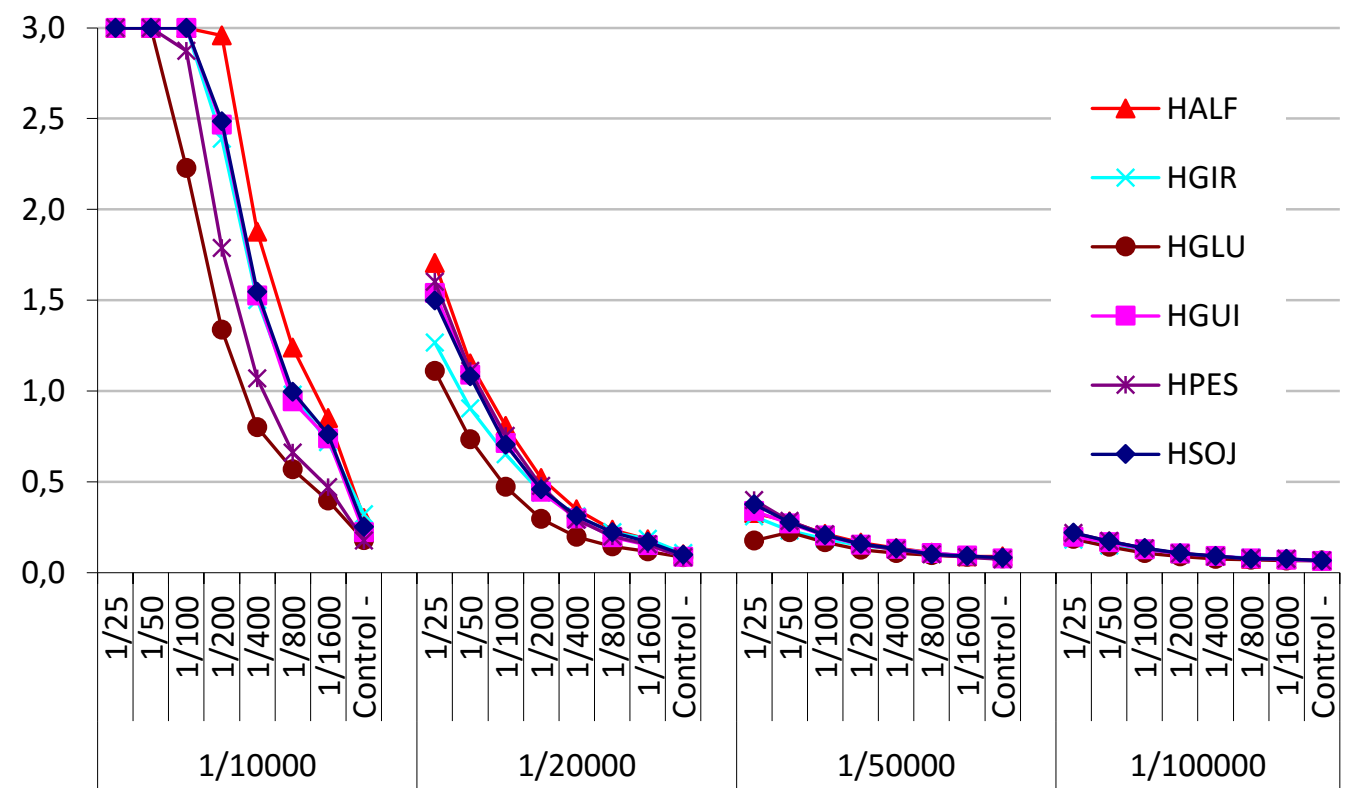

Figura 19. Absorbancia a $450 \mathrm{~nm}$ obtenida con distintas diluciones de un suero de coneja $(1 / 25,1 / 50,1 / 100,1 / 200,1 / 400,1 / 800,1 / 1600$ y control negativo) y de anticuerpo secundario $(1 / 10000,1 / 20000,1 / 50000$ y $1 / 100000)$ con los hidrolizados de las materias primas estudiadas 


\subsubsection{REPETIBILIDAD ENTRE PLACAS ELISA}

Las absorbancias del control negativo y del suero de referencia variaron con el hidrolizado utilizado en el tapizado de los pocillos $(P<0.001)$, con medias que oscilaron entre 0,056 (HALF) y 0,081 (HGLU) para el control negativo y 0,383 (HPES) y 1,355 (HGLU) para el suero de referencia. La Tabla 9 muestra la repetibilidad entre placas de ambas medidas, expresada como el coeficiente de variación residual.

Tabla 9. Absorbancia a $450 \mathrm{~nm}$ del control negativo y del suero de referencia $(n=34)$

\begin{tabular}{lccc}
\hline & Media & $\begin{array}{c}\text { Desviación estándar } \\
\text { residual }\end{array}$ & $\begin{array}{c}\text { Coeficiente de } \\
\text { variación residual (\%) }\end{array}$ \\
\hline Control negativo & 0,064 & 0,014 & 22,7 \\
Suero de referencia & 0,930 & 0,134 & 14,4 \\
\hline
\end{tabular}

\subsubsection{ANTICUERPOS FRENTE A ANTÍGENOS DIETARIOS EN EL SUERO SANGUÍNEO DE GAZAPOS ALIMENTADOS CON LOS PIENSOS EXPERIMENTALES Y SUS MADRES}

\subsubsection{SUEROS DE LAS CONEJAS}

Los sueros de las conejas madres extraídos al parto presentaron IgG frente a todos los hidrolizados testados. Como puede verse en la Figura 20, se detectaron diferencias significativas en función del hidrolizado al que se enfrentaron. La absorbancia fue máxima frente a HGLU y mínima frente a HPES, con valores intermedios frente a HALF, HGIR, HGUI y HSOJ.

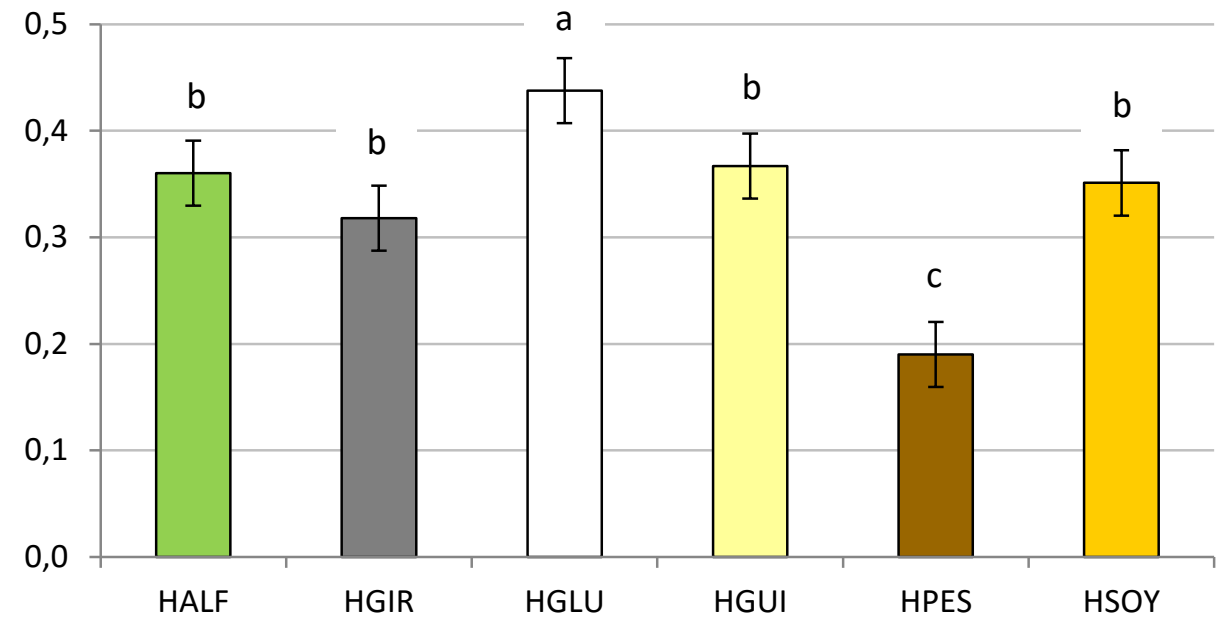

Figura 20. Absorbancia a $450 \mathrm{~nm}$ de sueros de conejas obtenidos al parto en función del hidrolizado utilizado para tapizar los pocillos. Media ajustada por Mínimos Cuadrados \pm Error Estándar de la Media $(n=35)$. Letras distintas indican diferencias significativas con $P<0,05$ 


\subsubsection{SUEROS DE LOS GAZAPOS}

Los sueros iniciales de los gazapos, tomados a los 25 días de vida, también presentaron IgG frente a todos los hidrolizados testados. Como ilustra la Figura 21, también se detectaron diferencias significativas en función del hidrolizado utilizado para el tapizado de los pocillos, con valores máximos cuando se enfrentaron a HALF y HGIR, seguidos por los obtenidos cuando se enfrentaron a HGLU y HSOJ, después por los obtenidos cuando se enfrentaron a HGUI y con el mínimo valor cuando se enfrentaron a HPES.

Los valores obtenidos fueron menores que los observados en los sueros de las conejas madres en el caso de $\operatorname{HALF}(-0,125 \pm 0,036 ; P<0,001), \operatorname{HGIR}(-0,076 \pm 0,036 ; P=0,035)$, HGLU $(-0,223 \pm 0,036 ; P<0,001)$, HGUI $(-0,165 \pm 0,036 ; P<0,001)$ y HSOJ $(-0,137 \pm 0,036$; $P<0,001)$ pero no en el caso de HPES $(-0,024 \pm 0,036 ; P=0,498)$.

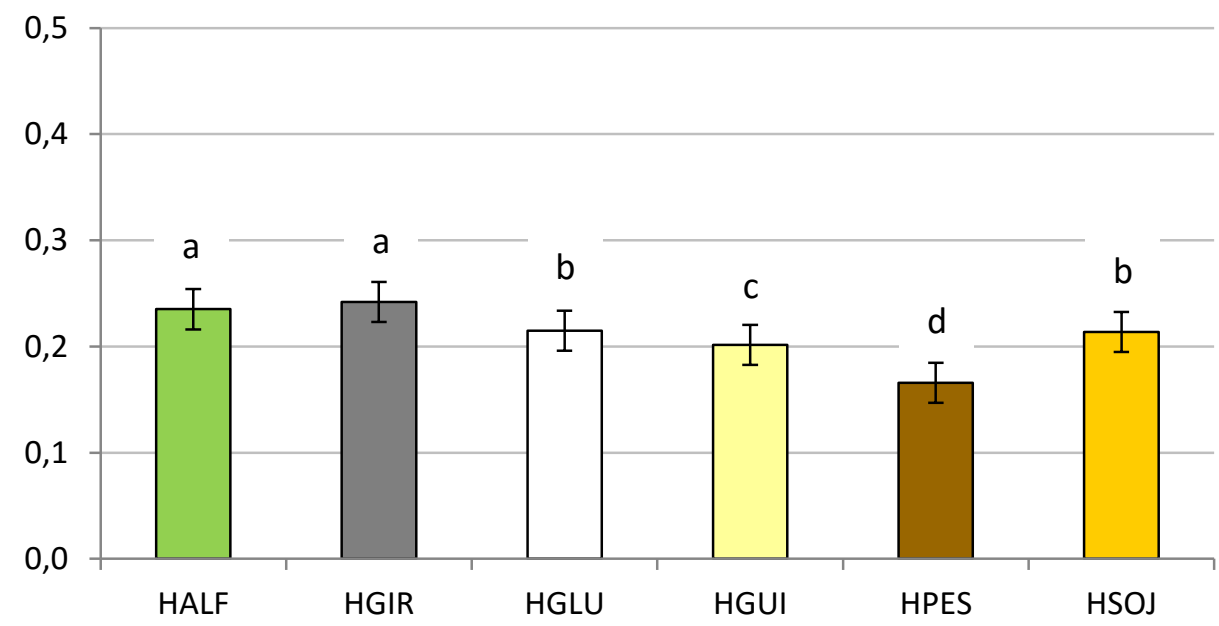

Figura 21. Absorbancia a $450 \mathrm{~nm}$ de los sueros iniciales de los gazapos (25 días de vida) en función del hidrolizado utilizado para tapizar los pocillos. Media ajustada por Mínimos Cuadrados \pm Error Estándar de la Media $(n=84)$. Letras distintas indican diferencias significativas con $P<0,05$

Las diferencias de absorbancia entre los sueros finales ( 58 días de vida) e iniciales ( 25 días de vida) de los gazapos alimentados con los distintos piensos experimentales se muestran de la Figura 22 a la Figura 29, en función del hidrolizado utilizado para el tapizado de los pocillos, ya que se observó una interacción significativa entre ambos factores $(P<0,001)$. 
En el caso de los gazapos alimentados con el Pienso ALF (Figura 22) se observó un mayor aumento de absorbancia cuando los sueros se enfrentaron a HALF que cuando se enfrentaron a HGIR, HGUI y HPES, con valores intermedios cuando se enfrentaron a HGLU y HSOJ.

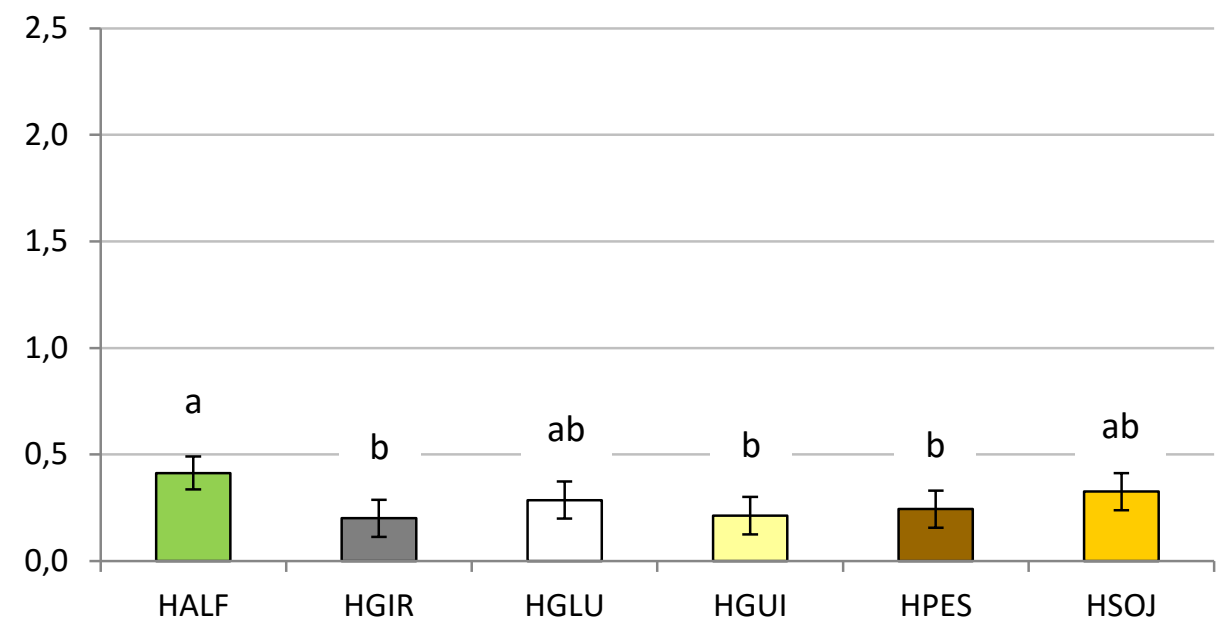

Figura 22. Aumento de absorbancia a $450 \mathrm{~nm}$ entre los sueros iniciales ( 25 días de vida) y finales (58 días de vida) de los gazapos alimentados con el Pienso ALF, en función del hidrolizado utilizado para tapizar los pocillos. Media ajustada por Mínimos Cuadrados \pm Error Estándar de la Media $(n=12)$. Letras distintas indican diferencias significativas con $P<0,05$

Los gazapos alimentados con el Pienso GIR (Figura 23) presentaron un mayor aumento de absorbancia cuando los sueros se enfrentaron a HGIR que cuando se enfrentaron a los hidrolizados de las restantes fuentes proteicas.

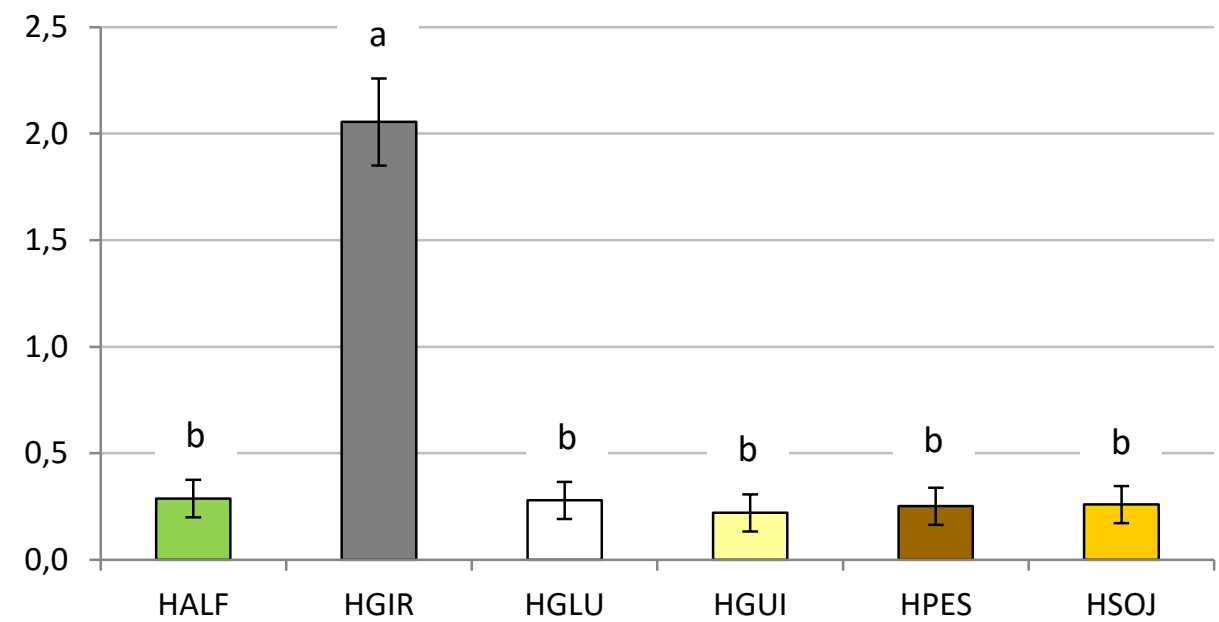

Figura 23. Aumento de absorbancia a $450 \mathrm{~nm}$ entre los sueros iniciales ( 25 días de vida) y finales (58 días de vida) de los gazapos alimentados con el Pienso GIR, en función del hidrolizado utilizado para tapizar los pocillos. Media ajustada por Mínimos Cuadrados \pm Error Estándar de la Media $(n=12)$. Letras distintas indican diferencias significativas con $\mathrm{P}<0,05$ 
De forma análoga, los gazapos alimentados con el Pienso GLU (Figura 24) presentaron un mayor aumento de absorbancia cuando los sueros se enfrentaron a HGLU que cuando se enfrentaron a los hidrolizados de las restantes fuentes proteicas.

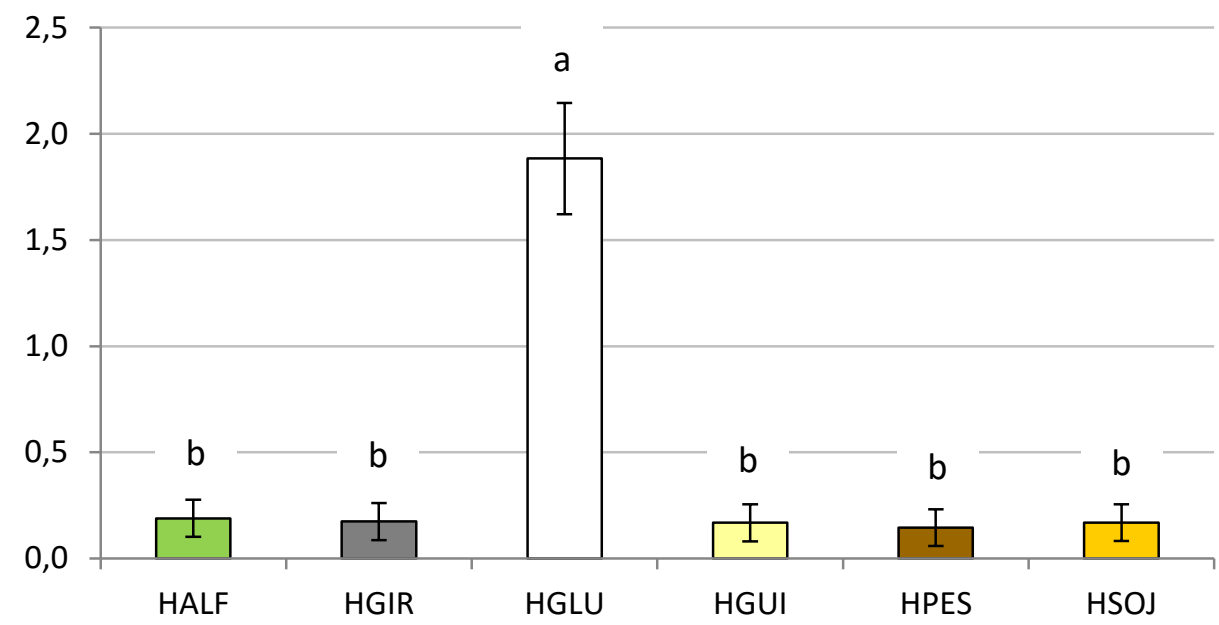

Figura 24. Aumento de absorbancia a $450 \mathrm{~nm}$ entre los sueros iniciales ( 25 días de vida) y finales (58 días de vida) de los gazapos alimentados con el Pienso GLU, en función del hidrolizado utilizado para tapizar los pocillos. Media ajustada por Mínimos Cuadrados \pm Error Estándar de la Media $(n=12)$. Letras distintas indican diferencias significativas con $P<0,05$

En el caso de los gazapos alimentados con el Pienso GUI (Figura 25) también se observó un mayor aumento de absorbancia cuando los sueros se enfrentaron a HGUI que cuando se enfrentaron a los hidrolizados restantes. El aumento también fue mayor cuando se utilizó HGLU que con HALF, HGIR, HPES y HSOJ.

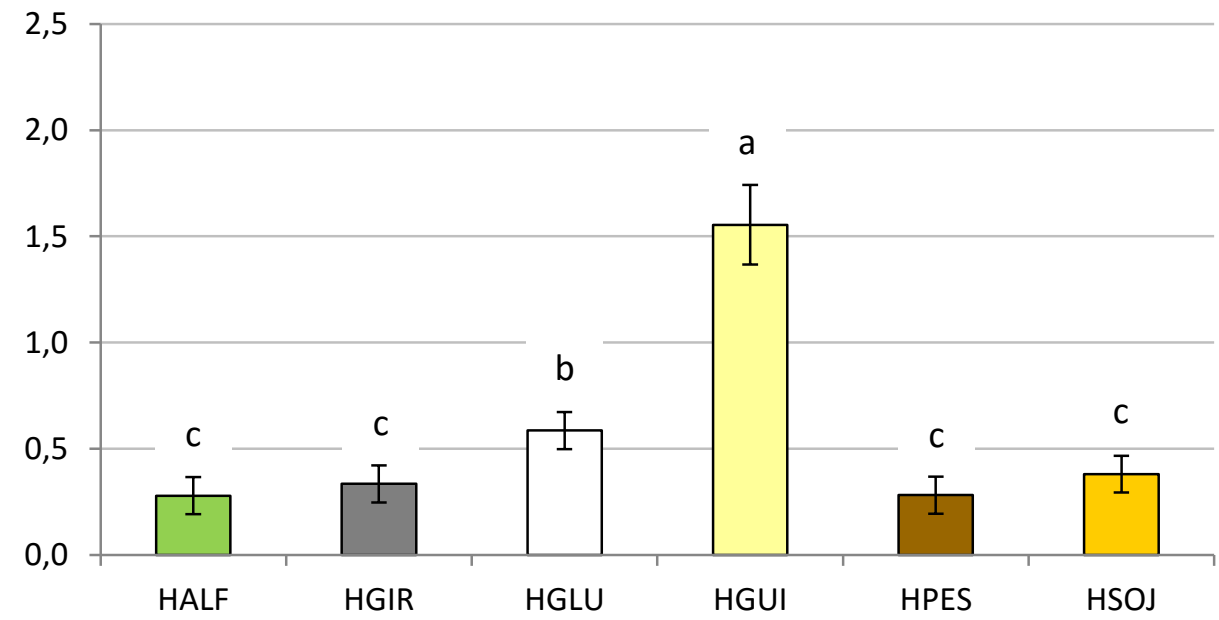

Figura 25. Aumento de absorbancia a $450 \mathrm{~nm}$ entre los sueros iniciales (25 días de vida) y finales (58 días de vida) de los gazapos alimentados con el Pienso GUI, en función del hidrolizado utilizado para tapizar los pocillos. Media ajustada por Mínimos Cuadrados \pm Error Estándar de la Media $(n=12)$. Letras distintas indican diferencias significativas con $\mathrm{P}<0,05$ 
Los gazapos que consumieron el Pienso PES (Figura 26) mostraron mayor aumento de absorbancia cuando los sueros se enfrentaron a HGLU que cuando se enfrentaron a HPES y HSOJ, con valores intermedios cuando se enfrentaron a HALF, HGIR y HGUI.

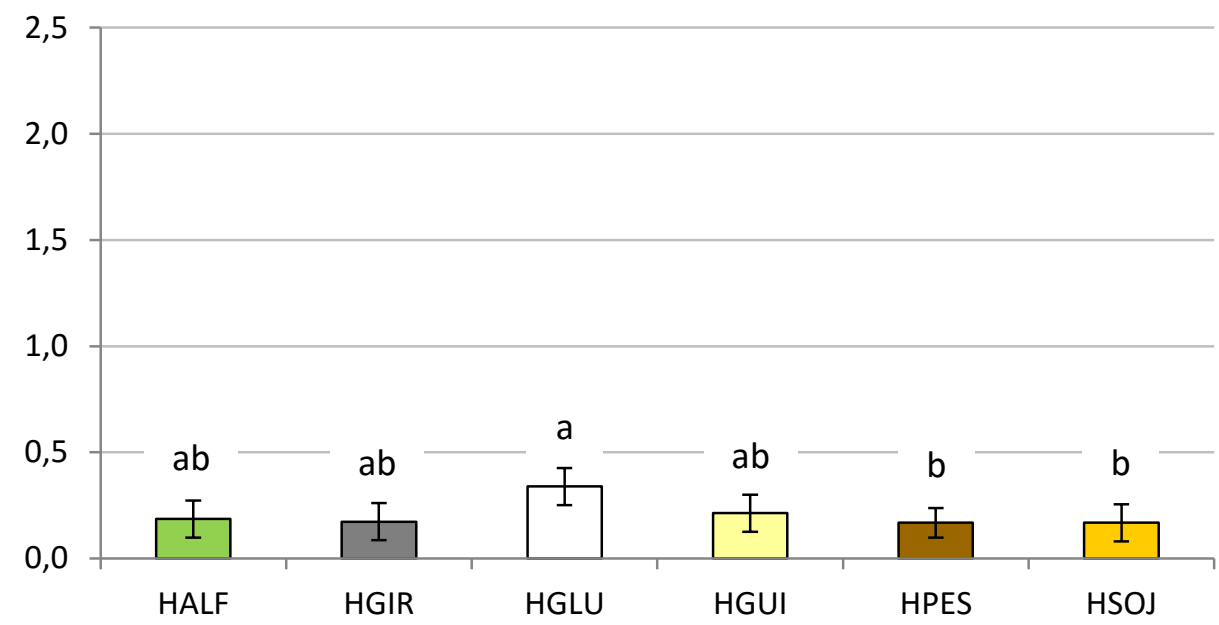

Figura 26. Aumento de absorbancia a $450 \mathrm{~nm}$ entre los sueros iniciales ( 25 días de vida) y finales (58 días de vida) de los gazapos alimentados con el Pienso PES, en función del hidrolizado utilizado para tapizar los pocillos. Media ajustada por Mínimos Cuadrados \pm Error Estándar de la Media $(n=12)$. Letras distintas indican diferencias significativas con $P<0,05$

Los gazapos alimentados con el Pienso SOJ (Figura 27) presentaron un mayor aumento de absorbancia cuando los sueros se enfrentaron a HSOJ que cuando se enfrentaron a los hidrolizados de las restantes fuentes proteicas. El aumento también fue mayor con HGUI que con HGIR y HPES, con valores intermedios con HALF y HGLU.

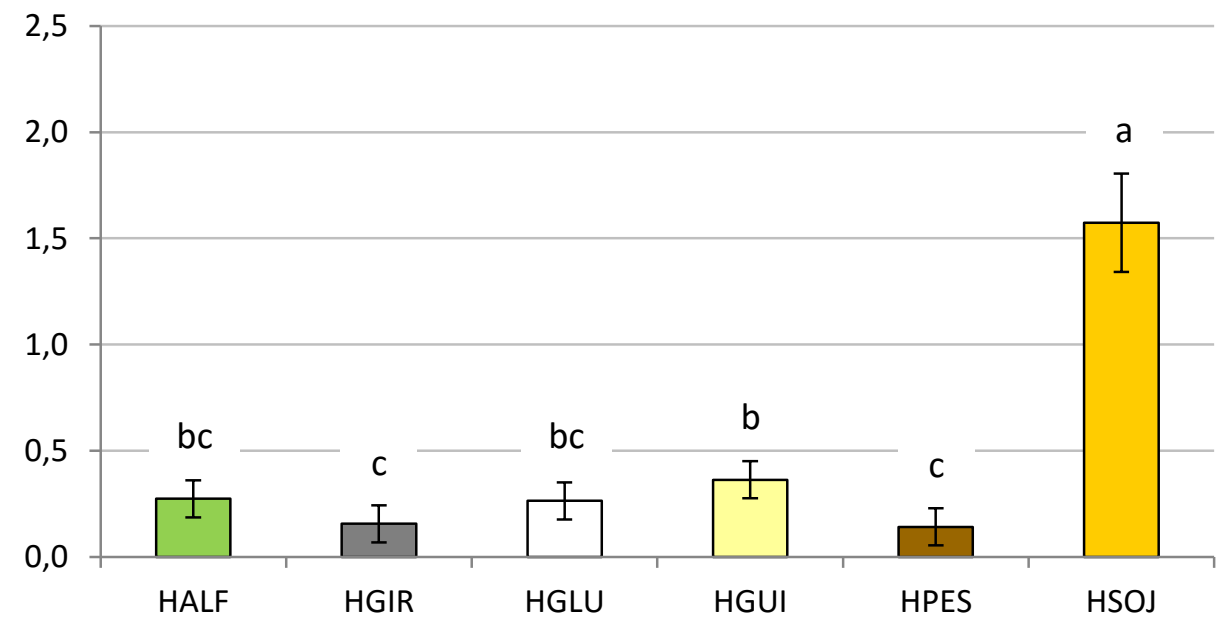

Figura 27. Aumento de absorbancia a $450 \mathrm{~nm}$ entre los sueros iniciales ( 25 días de vida) y finales (58 días de vida) de los gazapos alimentados con el Pienso SOJ, en función del hidrolizado utilizado para tapizar los pocillos. Media ajustada por Mínimos Cuadrados \pm Error Estándar de la Media $(n=12)$. Letras distintas indican diferencias significativas con $\mathrm{P}<0,05$ 
Centrándonos en el aumento de absorbancia registrado cuando los sueros de los gazapos se enfrentaron al hidrolizado de la fuente proteica incluida en el pienso que consumieron (Figura 28), vemos que hay tres tipos de respuesta. Por un lado, GIR, GLU, GUI y SOJ dieron lugar a un aumento de absorbancia entre 1,5 y 2,0, claramente mayor que el observado con ALF, que a su vez fue mayor que el registrado con PES.

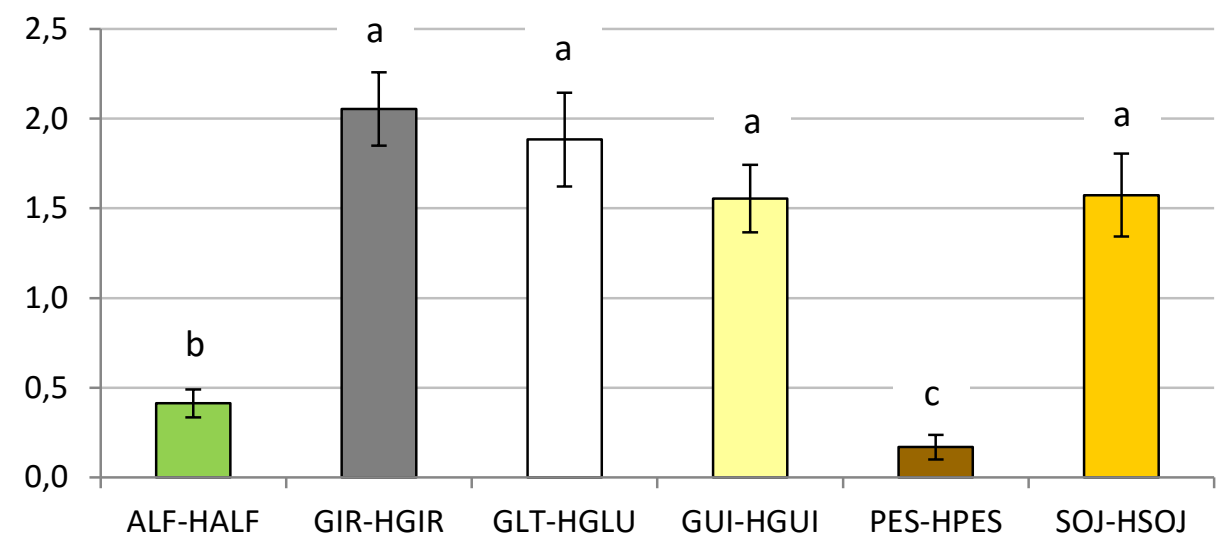

Figura 28. Aumento de absorbancia a $450 \mathrm{~nm}$ entre los sueros iniciales ( 25 días de vida) y finales (58 días de vida) de los gazapos de los gazapos alimentados con los distintos piensos cuando se enfrentaron al hidrolizado de la fuente proteica incluida en el que consumieron. Media ajustada por Mínimos Cuadrados \pm Error Estándar de la Media $(n=12)$. Letras distintas indican diferencias significativas con $\mathrm{P}<0,05$

Por otro lado, los animales alimentados con el Pienso MIX (Figura 29) presentaron mayor aumento de absorbancia frente a HGUI que frente a HSOJ, frente a HSOJ que frente a HGIR y HGLU) y frente a HGIR y HGLU que frente a HALF y HPES. Estos valores fueron menores que los presentados en la Figura 28 para $\operatorname{GIR}(-1,588 \pm 0,222 ; P<0,001)$, GLU $(-1,336 \pm 0,276 ; P<0,001)$, GUI $(-0,525 \pm 0,207 ; P=0,011)$ y SOJ $(-0,794 \pm 0,247 ; P=0,001)$ pero no para $\operatorname{ALF}(-0,161 \pm 0,117 ; P=0,170)$ y $\operatorname{PES}(0,095 \pm 0,112 ; P=0,396)$.

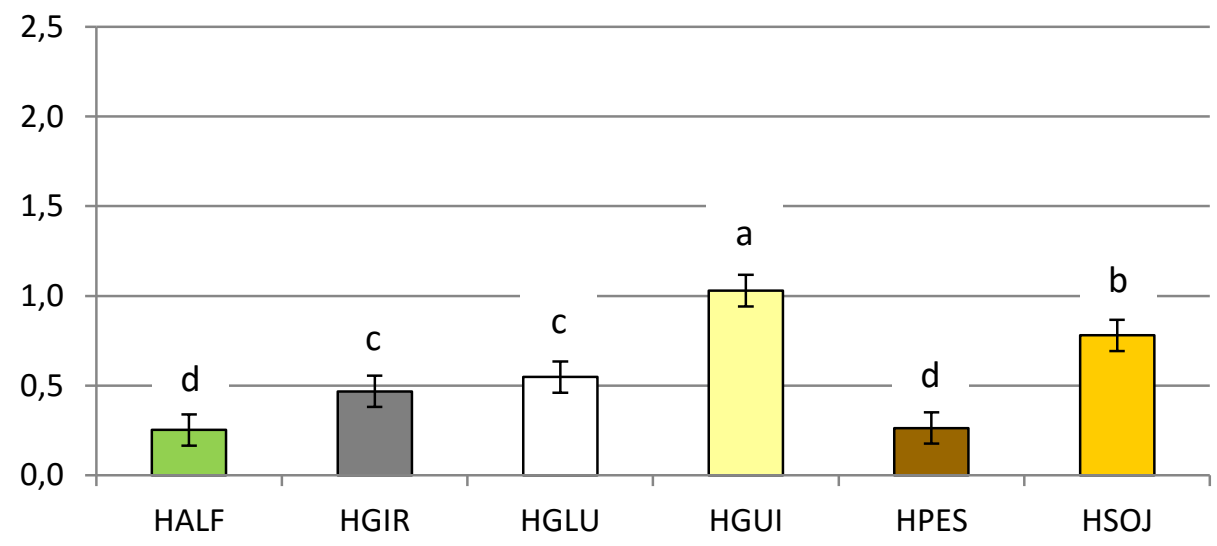

Figura 29. Aumento de absorbancia a $450 \mathrm{~nm}$ entre los sueros iniciales (25 días de vida) y finales (58 días de vida) de los gazapos alimentados con el Pienso MIX, en función del hidrolizado utilizado para tapizar los pocillos. Media ajustada por Mínimos Cuadrados \pm Error Estándar de la Media $(n=12)$. Letras distintas indican diferencias significativas con $P<0,05$ 


\subsubsection{HISTOMORFOLOGÍA E INMUNOHISTOQUÍMICA DE LA MUCOSA YEYUNAL}

En la Tabla 10 se presentan los resultados correspondientes a los parámetros histomorfológicos medidos en la mucosa yeyunal: altura de las vellosidades, profundidad de las criptas y ratio entre ellas. Se observaron diferencias relevantes en la altura de las vellosidades y en la ratio entre la altura de las vellosidades y la profundidad de las criptas entre algunos piensos, que sin embargo no resultaron estadísticamente significativas.

Tabla 10. Altura de las vellosidades y profundidad de las criptas $(\mu \mathrm{m})$ en la mucosa yeyunal de gazapos de 29 días de vida alimentados con piensos formulados con diferentes fuentes proteicas (MMC)

\begin{tabular}{lccccccccc}
\hline & $\begin{array}{c}\text { ALF } \\
(n=9)\end{array}$ & $\begin{array}{c}\text { GIR } \\
(n=10)\end{array}$ & $\begin{array}{c}\text { GLU } \\
(n=8)\end{array}$ & $\begin{array}{c}\text { GUI } \\
(n=10)\end{array}$ & $\begin{array}{c}\text { PES } \\
(n=7)\end{array}$ & $\begin{array}{c}\text { SOJ } \\
(n=10)\end{array}$ & $\begin{array}{c}\text { MIX } \\
(n=9)\end{array}$ & DER & $P$ \\
\hline $\begin{array}{l}\text { Altura } \\
\text { vellosidades (A) }\end{array}$ & 483 & 529 & 438 & 457 & 559 & 485 & 566 & 102 & 0,085 \\
$\begin{array}{l}\text { Profundidad } \\
\text { criptas (B) }\end{array}$ & 104 & 105 & 103 & 116 & 104 & 105 & 112 & 14 & 0,408 \\
\begin{tabular}{l} 
Ratio A/B \\
\hline
\end{tabular} & 4,70 & 5,09 & 4,21 & 4,02 & 5,38 & 4,65 & 5,15 & 1,10 & 0,129 \\
\hline
\end{tabular}

MMC: Media ajustada por Mínimos Cuadrados; DER: Desviación Estándar Residual

La Tabla 11 muestra los resultados correspondientes a los parámetros inmunohistoquímicos valorados en la mucosa yeyunal de los gazapos alimentados con los piensos GLU, GUI y PES: recuentos de linfocitos $T$ en las vellosidades y de células $\mathrm{Ki67}^{+}$(en división) o Ki67- (no proliferantes) en las criptas.

Tabla 11. Recuentos de linfocitos $T$ en las vellosidades y de células en las criptas de la mucosa yeyunal de gazapos de 29 días de vida alimentados con piensos formulados con diferentes fuentes proteicas (MMC)

\begin{tabular}{lccccc}
\hline & $\begin{array}{c}\text { GLU } \\
(n=7)\end{array}$ & $\begin{array}{c}\text { GUI } \\
(n=7)\end{array}$ & $\begin{array}{c}\text { PES } \\
(n=7)\end{array}$ & DER & $P$ \\
\cline { 2 - 6 } Linfocitos T en vellosidades (no/vellosidad) & $13,7^{\mathrm{b}}$ & $30,3^{\mathrm{a}}$ & $10,3^{\mathrm{b}}$ & 7,5 & $<0,001$ \\
Células en criptas (no/campo) & $95,3^{\mathrm{b}}$ & $110,4^{\mathrm{a}}$ & $94,5^{\mathrm{b}}$ & 6,7 & $<0,001$ \\
$\quad$ Ki67 $^{+}$(en división) & $61,5^{\mathrm{b}}$ & $84,2^{\mathrm{a}}$ & $45,4^{\mathrm{c}}$ & 8,3 & $<0,001$ \\
Ki67 $^{-}$(no proliferantes) & $33,9^{\mathrm{b}}$ & $26,2^{\mathrm{b}}$ & $49,0^{\mathrm{a}}$ & 8,9 & $<0,001$ \\
\hline
\end{tabular}

MMC: Media ajustada por Mínimos Cuadrados; DER: Desviación Estándar Residual

a, b, c Valores con letras distintas difieren con $P<0,05$

Las vellosidades de los gazapos alimentados con GUI presentaron un mayor número de linfocitos T que las de los gazapos alimentados con GLU o PES (+153\%). Asimismo, en las criptas de los gazapos alimentados con GUI se observaron más células en división (Ki67 ${ }^{+}$) que en las de los gazapos alimentados con GLU (+37\%) y, sobre todo, con PES (+85\%). En contraste, el número de células no proliferantes (Ki67) fue menor con GUI y GLU que con PES (-39\%). Por otro lado, se observaron más células en división $\left(\mathrm{Ki}^{6} \mathrm{7}^{+}\right)$y menos células no proliferantes (Ki67-) con GLU que con PES (+35\% y -31\%, respectivamente). En consecuencia, el número total de células fue mayor con GUI que con GLU y PES (+16\%). 
La Tabla 12 recoge los coeficientes de correlación lineal simple entre los distintos parámetros histomorfológicos e inmunohistoquímicos de los gazapos alimentados con GLU, GUI y PES.

Tabla 12. Coeficientes de correlación lineal simple entre parámetros histomorfológicos e inmunohistoquímicos de la mucosa yeyunal de gazapos de 29 días de vida alimentados con diferentes fuentes de proteína (gluten de trigo, guisante, harina de pescado) $(n=21)$

\begin{tabular}{|c|c|c|c|c|c|}
\hline & AV & PC & LTV & $\mathrm{Ki} 7^{+}$ & Ki67- \\
\hline Altura de vellosidades (AV) & & $\begin{array}{c}-0,061 \\
0,794\end{array}$ & $\begin{array}{l}0,127 \\
0,582\end{array}$ & $\begin{array}{l}0,005 \\
0,984\end{array}$ & $\begin{array}{l}-0,011 \\
0,962\end{array}$ \\
\hline Profundidad de criptas (PC) & & & $\begin{array}{l}0,518 \\
0,016\end{array}$ & $\begin{array}{l}0,505 \\
0,019\end{array}$ & $\begin{array}{l}-0,558 \\
0,009\end{array}$ \\
\hline Linfocitos T en vellosidades (LTV) & & & & $\begin{array}{c}0,840 \\
<0,001\end{array}$ & $\begin{array}{l}-0,679 \\
<0,001\end{array}$ \\
\hline Células Ki67+ en criptas $\left(\mathrm{Ki} 67^{+}\right)$ & & & & & $\begin{array}{l}-0,848 \\
<0,001\end{array}$ \\
\hline Células Ki67 en criptas (Ki67) & & & & & \\
\hline
\end{tabular}

La altura de las vellosidades no mostró correlación con el resto de los parámetros, que sí estuvieron correlacionados entre sí. Cuando estas correlaciones se analizaron para cada uno de los piensos por separado, los valores obtenidos siempre tuvieron el mismo signo que los obtenidos con todos los piensos conjuntamente, aunque no alcanzaron el nivel de significación excepto para los casos de linfocitos $\mathrm{T}$ y células Ki67 ${ }^{+}$con $\mathrm{GUI}(\mathrm{r}=0,896$; $P=0,006)$, linfocitos T y células Ki67 con PES $(r=-0,757 ; P=0,049)$ y células Ki $67^{+}$y células Ki67 con GLU ( $r=-0,905 ; P=0,005)$. Por otro lado, las correlaciones parciales de primer o segundo orden solo siguieron siendo significativas $(P<0,001)$ entre linfocitos $T$ y células $\mathrm{Ki} \mathrm{7}^{+}$y entre células $\mathrm{Ki} 67^{+}$y células Ki67; cuya regresión se ilustra en la Figura 32; en el segundo caso, se obtuvo mejor ajuste mediante regresión cuadrática $(r=0,908 ; P<0,001)$.
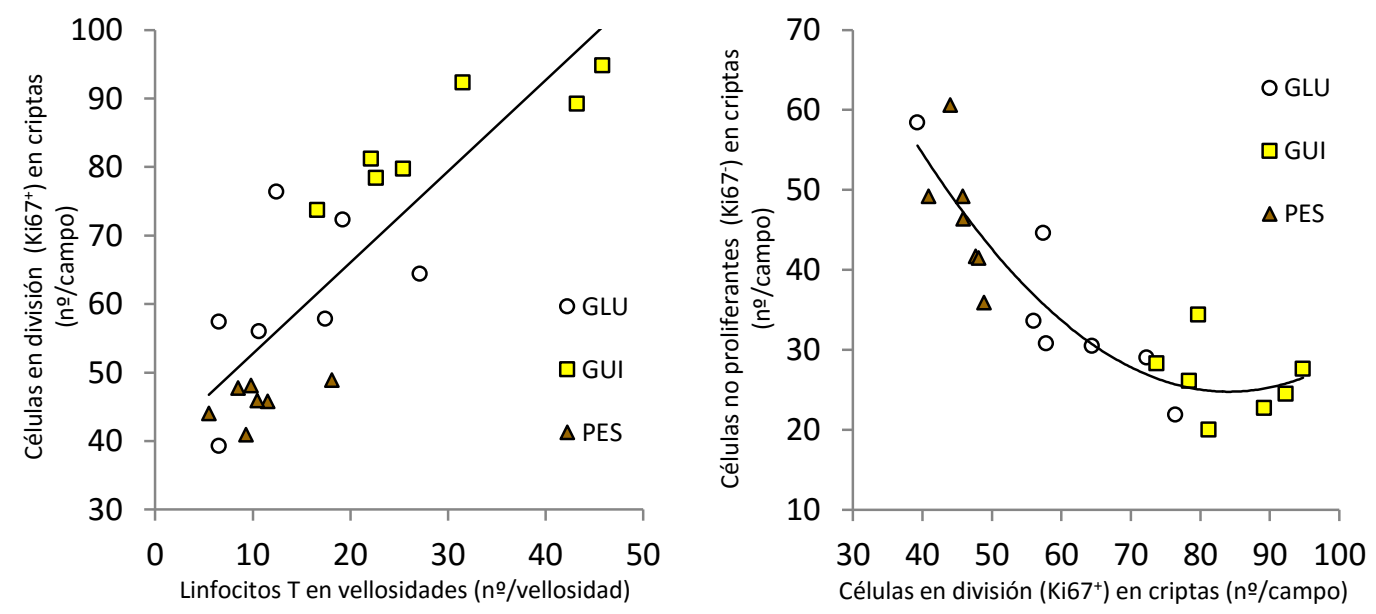

Figura 32. Relación entre parámetros inmunohistoquímicos de la mucosa yeyunal de gazapos de 29 días de vida alimentados con piensos formulados con diferentes fuentes de proteína $(n=21)$ 


\subsubsection{RESULTADOS PRODUCTIVOS}

La Tabla 13 recoge los rendimientos productivos que presentaron los animales en función del pienso que consumieron. Cabe destacar que la ingestión de pienso y la ganancia de peso fueron particularmente bajas en el caso del Pienso GLU. La ganancia de peso también fue menor de lo normal en el caso del Pienso PES, aunque la ingestión de pienso fue aparentemente muy similar a la observada con el Pienso GUI que presentó una ganancia de peso apreciablemente mayor.

Tabla 13. Rendimientos productivos con los piensos experimentales (MMC)

\begin{tabular}{|c|c|c|c|c|c|c|c|c|c|}
\hline & $\begin{array}{c}\text { ALF } \\
(n=32)\end{array}$ & $\begin{array}{c}\text { GIR } \\
(n=27)\end{array}$ & $\begin{array}{c}\mathrm{GLU} \\
(\mathrm{n}=30)\end{array}$ & $\begin{array}{c}\text { GUI } \\
(n=22)\end{array}$ & $\begin{array}{c}\text { PES } \\
(n=27)\end{array}$ & $\begin{array}{c}\text { SOJ } \\
(n=31)\end{array}$ & $\begin{array}{c}\mathrm{MIX} \\
(\mathrm{n}=24)\end{array}$ & DER & $P$ \\
\hline Peso 25 días (g) & 402 & 389 & 409 & 400 & 395 & 394 & 394 & 59 & 0,891 \\
\hline $\begin{array}{l}\text { Ganancia peso } \\
25-58 \text { días }(g / d)\end{array}$ & $42,1^{b}$ & $44,4^{a b}$ & $15,0^{d}$ & $44,5^{a b}$ & $34,1^{c}$ & $46,0^{a}$ & $47,0^{a}$ & 4,9 & $<0,001$ \\
\hline $\begin{array}{l}\text { Ingestión pienso }{ }^{1} \\
25-58 \text { días }(\mathrm{g} / \mathrm{d})\end{array}$ & $96^{a}$ & $95^{a b}$ & $40^{c}$ & $83^{b}$ & $82^{b}$ & $105^{a}$ & $95^{a}$ & 10 & $<0,001$ \\
\hline
\end{tabular}

MMC: Media ajustada por Mínimos Cuadrados; DER: Desviación Estándar Residual

$\mathrm{a}, \mathrm{b}, \mathrm{c}$ Valores con letras distintas difieren con $P<0,05$

${ }^{1} \mathrm{n}=5$ 

5. DISCUSIÓN 

La presente discusión se dividirá en dos partes: en la primera se discutirá la metodología desarrollada para valorar la presencia de anticuerpos frente a antígenos dietarios en suero de conejo y en la segunda se discutirán los resultados obtenidos en relación con la reacción inmunitaria del conejo frente a las distintas fuentes proteicas estudiadas.

\subsection{ASPECTOS METODOLÓGICOS}

De la revisión de trabajos publicados sobre el estudio de la capacidad antigénica de las proteínas de la dieta destacan las técnicas que estudian la reacción humoral detectando la presencia de anticuerpos específicos en suero sanguíneo. Este tipo de prueba tiene la ventaja de que se utiliza suero sanguíneo, que puede recogerse de forma conservativa desde edades muy tempranas, lo que en caso necesario permite realizar muestreos longitudinales amplios en condiciones de granja, desde animales lactantes hasta adultos.

El Dot Immunoblotting es una técnica de rutina en los laboratorios de inmunología, empleada para la detección de proteínas en membranas de nitrocelulosa. Esta técnica es sencilla de realizar, por lo que se eligió para las pruebas iniciales que trataban simplemente de dilucidar la presencia de anticuerpos frente a la dieta en el suero de conejo, comparando dos piensos distintos en cuanto al origen de su proteína. Cuando a la membrana de nitrocelulosa se transfieren las proteínas previamente separadas mediante electroforesis en gel de poliacrilamida es posible conocer el tamaño de las proteínas frente a las que hay anticuerpos específicos en el suero testado, tal como se observa en trabajos realizados en terneros (Dréau et al., 1995a; Dréau y Lallès, 1999) y lechones (Lallès et al., 2004).

Las desventajas que tiene esta técnica son que se necesitan grandes cantidades de suero, que su estandarización es difícil y que es esencialmente cualitativa o semicuantitativa. Para resolver estos problemas, la determinación de anticuerpos puede hacerse mediante ELISA.

Desde que Engvall y Perlmann (1971) la describieron por primera vez, la técnica ELISA se ha convertido en un método de elección para la detección y cuantificación de antígenos solubles y anticuerpos, debido a la alta sensibilidad y reproducibilidad de sus resultados. De los protocolos ELISA disponibles, se eligió el ELISA indirecto por ser el más adecuado para los objetivos de la presente investigación (Hornbeck et al., 1991). Esta técnica ha sido utilizada en la investigación de las reacciones inmunitarias frente a proteínas dietarias en humanos (Husby, 2000), ratones (Christensen et al., 2004), perros (WillisMahn et al., 2014), terneros (Timmermans et al., 1992), lechones (Bailey et al., 2004; Lallès et al., 2004; Li et al., 1991a; Hankins et al., 1992; Lallès et al., 2004) y conejos (March, 2003). 
En el mercado hay kits comerciales para análisis de anticuerpos frente a determinadas proteínas dietarias de conocida antigenicidad o al menos se puede disponer de tales proteínas para tapizar los pocillos de la placa ELISA. Así, para el caso de la soja se ha utilizado tanto proteína de soja purificada como glicinina o $\beta$-conglicinina (Li et al., 1991a) y en el caso del trigo se ha utilizado tanto gluten purificado como gliadina (March, 2003). Sin embargo, la presente investigación pretende valorar la presencia de anticuerpos frente a piensos y materias primas proteicas. Por ello, se tuvo que diseñar y desarrollar un protocolo propio para la obtención de los antígenos dietarios y la detección cuantitativa de anticuerpos frente a todos los componentes antigénicos del pienso o la materia prima estudiada.

En algunos estudios para el caso de la soja, se han empleado como antígenos diluciones de soja (Bailey et al., 2004) y extractos de soja obtenidos mediante incubación en tampón tris- $\mathrm{HCl}$ a pH 8 durante 1 hora a temperatura ambiente (Dréau et al., 1995a) o mediante incubación en tampón bicarbonato amónico y tratamiento con ultrasonidos (Christensen et al., 2004). En el caso de piensos y materias primas proteicas para cunicultura, donde la proporción de proteína insoluble y/o ligada a fibra puede ser elevada, parece oportuno el tratamiento con pepsina- $\mathrm{HCl}$ según un protocolo simplificado del método de digestión in vitro propuesto por Ramos et al. (1992). La pepsina provoca principalmente la ruptura de la estructura terciaria de las proteínas, deshaciendo sus plegamientos y produciendo péptidos de elevado peso molecular (Lehninger et al., 2008), de forma que con este protocolo de hidrólisis suave se obtiene una muestra representativa de los péptidos solubles del pienso o la materia prima. Además, se ha señalado que esta digestión proteica puede desenmascarar antígenos que permanecen ocultos al sistema inmunitario por la estructura terciaria de las proteínas (Dréau et al., 1995a).

El contenido proteico de los hidrolizados obtenidos varió particularmente en el caso de las materias primas estudiadas, probablemente en función tanto de su riqueza en proteína como de la solubilidad de la misma en pepsina- $\mathrm{HCl}$, aunque la información disponible sobre este parámetro es muy escasa. Es destacable el alto nivel del proteína del hidrolizado de la harina de soja, más del doble que la siguiente materia prima (gluten de trigo); en ese sentido, Wilfart et al. (2008) encontraron que la digestibilidad in vitro con pepsina de la harina de soja fue el doble que la registrada para trigo, cebada y salvado de trigo. Por otro lado, resulta sorprendente que el hidrolizado de la harina de pescado, pese a ser una materia prima con un elevado nivel de proteína (65\% PB, sobre $\mathrm{MS}$ ), dio lugar al hidrolizado con la más baja concentración proteica, similar a la de materias primas sensiblemente más pobres en proteína y con parte de ella ligada a fibra como la harina de girasol (30\% PB y 4.7\% PB ligada a fibra neutro detergente, sobre MS) y la alfalfa ( $16 \%$ PB\% y $5.0 \%$ PB ligada a fibra neutro detergente, sobre MS). Además, Mehrez et al. (1980) obtuvieron elevados valores de digestibilidad in vitro con pepsina para distintas harinas de pescado, si bien en todos los casos se reincorporaba la fracción obtenida por prensado, centrifugación, separación del aceite y deshidratación (solubles 
de pescado); esta reincorporación iría a favor de la digestibilidad in vitro con pepsina y quizá no se produjo en la harina de pescado utilizada en el presente estudio.

Dada la heterogeneidad del contenido proteico de los hidrolizados, se consideró necesario estandarizarlo antes de realizar el proceso de tapizado de los pocillos, mediante las diluciones oportunas, ya que la concentración del antígeno utilizada para el tapizado puede afectar a los resultados (Hornbeck et al., 1991). De esta forma, los resultados del ELISA son independientes del nivel y la naturaleza de la proteína en los piensos o materias primas estudiadas.

Como control negativo del protocolo ELISA se utilizó PBS. La absorbancia medida en estos pocillos expresa las uniones inespecíficas de los anticuerpos secundarios conjugados con peroxidasa a las proteínas de los distintos hidrolizados y la BSA utilizada para el bloqueo de los pocillos. Los valores de absorbancia obtenidos con los distintos hidrolizados fueron muy bajos en los dos experimentos (Experimento I: 2 placas; Experimento III: 34 placas), lo que resulta indicativo de un bajo nivel de estas uniones inespecíficas. En cualquier caso, estos valores se restaron de la absorbancia obtenida en las muestras de suero analizadas.

En el Experimento III se utilizó como control positivo un suero de referencia (suero medio obtenido con $100 \mu \mathrm{L}$ de los sueros finales de dos conejos de cada uno de piensos), que se analizó en todas las placas ELISA. Este control interno se estableció para detectar posibles variaciones entre placas por causas instrumentales o ambientales. La repetibilidad de las medidas entre placas fue aceptable para esta técnica, ya que el CV residual fue del 14\%, en la línea de otros estudios (Edder et al., 1999; Scortichini et al., 2005; Girotti et al., 2010).

\subsection{DETERMINACIÓN DE IgG FRENTE A LOS HIDROLIZADOS DE PIENSOS Y MATERIAS PRIMAS EN CONEJOS}

\subsubsection{PRESENCIA DE IgG fRENTE ANTÍGENOS DietARIOS EN EL SUERO DE CONEJAS ADULTAS}

Los resultados obtenidos en el Experimento I (Dot Immunoblotting) y en el Experimento II (ELISA) permitieron poner de manifiesto que las conejas adultas tienen IgG frente a antígenos dietarios presentes en los hidrolizados de piensos, tanto del pienso comercial que consumían como de dos piensos experimentales que no habían consumido y que eran divergentes en cuanto al origen de la proteína. Estos resultados fueros confirmados en el Experimento III (ELISA) empleando hidrolizados de seis fuentes proteicas distintas (heno de alfalfa, harina de girasol, guisante, gluten de trigo, harina de pescado y harina de soja). Esta presencia de anticuerpos frente a antígenos dietarios en conejas adultas resulta, a priori, sorprendente si entendemos la tolerancia oral como un mecanismo 
encaminado a evitar un respuesta sistémica frente a los antígenos dietarios (Tizard, 2013).

La regulación de la reacción inmune en el intestino es especialmente compleja. La enorme cantidad de antígenos e interacciones dinámicas que concurren favorece un ambiente tolerante frente a los antígenos dietarios (Mason et al., 2008). En otras palabras, en condiciones normales se limita la respuesta intensa de tipo reactivo frente a los antígenos dietarios en favor de una respuesta tolerogénica, de tipo regulador o supresor. En humanos en condiciones normales, se ha observado que no hay una respuesta sustancial de IgG a nivel de la mucosa intestinal (Brandtzaeg, 2002) y que la respuesta sistémica de IgG frente a antígenos dietarios disminuye con la edad, lo que es consistente con el desarrollo de un estado de baja respuesta sistémica por la estimulación antigénica continua del sistema inmunitario intestinal (Rothberg et al., 1965; Scott et al., 1985).

En este contexto, la presencia de IgG frente a proteínas dietarias en el suero de individuos adultos sanos es muy habitual. Así, se ha visto en humanos para diferentes proteínas, tales como $\alpha$-lactoalbúmina, $\beta$-lactoglobulina, $\alpha$-caseína y ovoalbúmina (Husby, 2000). De forma análoga, se ha descrito la presencia de anticuerpos anti-soja en el suero de cerdas (al parto y a los 21 días de lactación) que habían sido alimentadas con una dieta sin soja desde la semana previa al parto (Dréau et al., 1994). Asimismo, March (2003) detectó IgG anti-gliadina en conejos de laboratorio adultos que consumían una dieta con salvado de trigo y no en conejos silvestres pero tampoco en ratones adultos que consumían una dieta con trigo, por lo que parece que la exposición oral a antígenos dietarios no siempre produce una respuesta de IgG circulantes en animales adultos.

En sentido contrario, Knippels et al. (1998) observaron la presencia de IgG anti-soja en ratas de más de 6 meses alimentadas durante todo su vida con una dieta libre de soja e incluso en la siguiente generación alimentada también con la dieta libre de soja, todas ellas descendientes de animales alimentados con una dieta con soja durante varias generaciones. La presencia de anticuerpos frente a antígenos dietarios en animales que nunca han estado oralmente expuestos se explica por la transferencia maternal de antígenos, linfocitos B o anticuerpos por vía placentaria o/y a través de la leche (Knippels et al., 1998; Arvola et al., 2000; Bednar-Tantscher et al., 2001; Christensen et al., 2004).

En el presente estudio no se pudo disponer de un historial detallado de las materias primas incluidas en los piensos comerciales que habían consumido las conejas en sus, aproximadamente, 5-6 meses de vida ni tampoco en los que habían consumido sus madres. La mayoría de las fuentes de proteína utilizadas en los piensos experimentales ( $y$, obviamente, las empleadas en el pienso comercial) son, en mayor o menor medida, utilizadas en la alimentación del conejo. Es el caso del heno de alfalfa, la harina de girasol, el guisante y la harina de soja. Por el contrario, el gluten de trigo no se utiliza en la fabricación de piensos, pero la presencia de IgG frente al gluten de trigo se puede 
explicar considerando que el trigo y el salvado de trigo $u$ otros subproductos de su molinería sí están presentes habitualmente en la formulación de los piensos de conejos. En definitiva, es muy probable que las conejas hayan consumido estas materias primas a lo largo de su vida y que se hayan desencadenado respuestas inmunitarias detectables en forma de IgG en su suero sanguíneo.

Por el contrario, la probabilidad de que las conejas hayan consumido a lo largo de su vida piensos que incluyeran harina de pescado es nula, ya que esta materia prima está excluida de la formulación en la fábrica proveedora del pienso comercial. La cantidad de IgG frente a los antígenos presentes en el hidrolizado fue claramente menor con harina de pescado que con el resto de las fuentes proteicas testadas, por lo que esta presencia puede explicarse por uniones inespecíficas de anticuerpos del suero sanguíneo de las conejas con péptidos del hidrolizado de harina de pescado. El hecho de que la absorbancia frente a este hidrolizado fuera mínima y el único caso en que no era mayor que la de los sueros de los gazapos estrictamente lactantes avalaría esta hipótesis.

\subsubsection{PRESENCIA DE IgG fRENTE A ANTÍGENOS DIETARIOS EN EL SUERO Del GAZAPOS ESTRICTAMENTE LACTANTES: TRANSFERENCIA MATERNA}

En el Experimento I se evidenció la presencia de IgG frente a antígenos presentes en hidrolizados de sendos piensos experimentales, divergentes en cuanto al origen de la proteína, en sueros de gazapos de 21 días de vida estrictamente lactantes. En el Experimento II se confirmaron estos resultados mediante la técnica ELISA y no se detectaron diferencias significativas en la absorbancia de estos sueros cuando se enfrentaron a los hidrolizados de ambos piensos. De forma análoga, en el Experimento III se detectó la presencia, en mayor o menor medida, de anticuerpos frente a los antígenos presentes en los hidrolizados de todas las materias primas testadas en los gazapos de 25 días de vida estrictamente lactantes. Tanto en el Experimento II como en el Experimento III los valores de absorbancia obtenidos fueron menores que los detectados en el suero de las conejas, salvo en el caso reseñado en el apartado anterior.

La absorbancia del suero de los gazapos estrictamente lactantes no estaba correlacionada de forma significativa con la del suero de sus madres (a 21 y 56 días postparto en el Experimento II; al parto en el Experimento III), independientemente de que los datos se utilizaran conjuntamente o separados por hidrolizados (HA y $\mathrm{HB}$ en el Experimento II; HALF, HGIR, HGLU, HGUI, HPES y HSOY en el Experimento III). Esta falta de correlación se asoció a la gran variabilidad entre gazapos de una misma camada.

La presencia de anticuerpos frente a antígenos dietarios en gazapos que no habían consumido pienso solo puede explicarse, como se ha mencionado anteriormente, por la transferencia maternal de anticuerpos, linfocitos B o antígenos por vía calostral o/y vía placentaria. Los resultados obtenidos en lechones apuntan a una contribución preferente de la transferencia de anticuerpos. Así, se ha demostrado la presencia de 
altas concentraciones de IgG anti-soja en lechones de un día de vida, que disminuyeron a lo largo de las tres primeras semanas de vida, independientemente de que hubiera o no exposición sistemática a la proteína de soja mediante sonda gástrica, para aumentar una semana después del destete con un pienso a base de harina de soja (Hankins et al., 1992). En un experimento similar, Dréau et al. (1994) observaron una evolución parecida de los anticuerpos anti-soja en el suero de lechones, aunque no observaron el mencionado incremento transcurrida una semana desde el destete. También Miller et al. (1994) observaron la presencia de IgG anti-soja y no anti-ovoalbúmina en lechones de dos semanas estrictamente lactantes. Telemo et al. (1991) detectaron la presencia de anticuerpos anti-ovoalbúmina, y de ovoalbúmina, en lechones estrictamente lactantes cuyas madres habían ingerido ovoalbúmina durante la gestación.

En el conejo se produce transferencia maternal de IgG vía calostro y vía placentaria a través de su placenta hemocorial (Drouet-Viard y Fortun-Lamothe, 2002), pero hasta el momento no se disponía de información específica sobre la posible transferencia de anticuerpos frente a antígenos dietarios. Tampoco se dispone de información sobre el papel que desempeñaría la leche de coneja como fuente de IgA para actuar a nivel local en el intestino de la camada y conferir protección pasiva por exclusión de antígenos dietarios (Mason et al., 2008) o como fuente de IgG que forman inmunocomplejos con antígenos dietarios transportados a través del epitelio intestinal, por un mecanismo dependiente de receptores de IgG presentes en los enterocitos, que inducen una respuesta tolerogénica mediada por linfocitos T reguladores (Berin, 2012).

Se ha postulado que la transferencia materna de antígenos dietarios y de anticuerpos específicos frente a los mismos puede conducir a una hiporeactividad inmunológica específica y que este mecanismo tendría un papel importante en el destete (Dréau et al., 1994). Una de las preguntas que surge con la presencia de antígenos dietarios y de IgG específicas frente a los mismos, en parte formando inmunocomplejos, en el suero sanguíneo de animales adultos que han desarrollado tolerancia oral es su utilidad y significado fisiológico. Un proceso que se ha conservado en la evolución de las especies de mamíferos debe tener alguna ventaja adaptativa que justifique su mantenimiento pese a su coste metabólico e inmunitario. La respuesta puede estar precisamente en la protección que confiere a la descendencia: mediante un mecanismo similar al que ocurre con las enfermedades infecciosas, la madre mantiene la capacidad de producir y transferir anticuerpos específicos frente a los antígenos de la dieta que está consumiendo de forma habitual y que en condiciones naturales sería la que comenzaría a consumir su descendencia, que tendrán un efecto protector aminorando las respuestas inmunitarias de los gazapos frente a antígenos inocuos. En esa línea, se ha comprobado que la transferencia maternal de anticuerpos anti-gliadina en humanos podría tener un efecto protector frente a la enfermedad celíaca (Brandtzaeg, 2002). 


\subsubsection{EVOLUCIÓN DE LAS IgG FRENTE A ANTÍGENOS DIETARIOS EN EL SUERO DE LOS GAZAPOS EN CEBO: ANTIGENICIDAD DE LAS DISTINTAS MATERIAS PRIMAS PROTEICAS}

De forma cualitativa en el Experimento I y de forma cuantitativa en el Experimento II, se vio que el aumento del nivel sérico de IgG frente a antígenos dietarios era mayor en los animales que durante el cebo habían consumido un pienso con proteína procedente esencialmente de harina de soja que en los que habían consumido un pienso donde las fuentes proteicas eran heno de alfalfa, trigo y harina de pescado. La técnica de Dot Immunoblotting $y$, en particular, la técnica ELISA resultan, por tanto, adecuadas para medir la antigenicidad de un pienso y serían una herramienta muy útil para el cribado rápido de la antigenicidad de piensos incluso aunque no se conozca su composición, ya que permitirían detectar y cuantificar la presencia de IgG frente a antígenos dietarios en los conejos que lo han consumido.

El siguiente paso fue desarrollar un ELISA para la detección de IgG frente a antígenos dietarios que permitiera analizar diferentes materias primas proteicas de forma independiente y poder estudiar así su antigenicidad de forma separada. Los resultados del Experimento III reflejan diferentes niveles de antigenicidad entre las materia primas valoradas, ya que el aumento en los niveles circulantes de IgG específicas fue sensiblemente mayor para harina de girasol, gluten de trigo, guisante y harina de soja que para heno de alfalfa y harina de pescado.

La información disponible sobre esta materia en conejos es muy escasa y se limita a la detección de IgG anti-gliadina en el suero de conejos de laboratorio alimentados con una dieta que contenía salvado de trigo, hasta niveles similares a los provocados por la inmunización con gluten purificado por vía subcutánea (March, 2003), de forma similar a lo que ocurre en terneros (Timmermans et al., 1992).

La antigenicidad de la harina de soja ha sido muy estudiada en lechones y terneros (Bailey y Haverson, 2006) y también se sabe que la utilización de guisante en piensos de iniciación de lechones provoca un aumento de IgG específicas en mucha mayor medida que la caseína (Salgado et al., 2002a). Por el contrario, no se ha encontrado información sobre la antigenicidad de la harina de girasol, probablemente por su escasa utilización en piensos para lechones y terneros (De Blas et al., 2010).

Por otro lado, el heno alfalfa se mostró poco antigénico, a pesar de ser una leguminosa como la soja y el guisante. La antigenicidad de las leguminosas se asocia a proteínas presentes en las semillas (Brenes y Brenes, 1993) y por tanto, en principio, ausentes en la planta en pre- y post-floración. En la misma línea, la harina de pescado resultó ser de baja antigenicidad, tal como se asume para ésta y otras materias primas de origen animal (Orr, 2003), aunque no se ha encontrado información sobre niveles circulantes de IgG frente a proteínas del pescado. 
Los piensos experimentales formulados incluían elevados niveles de una única fuente de proteína. Para poder ver el efecto de la inclusión simultánea de todas estas materias primas en un único pienso se formuló el pienso MIX, en la que cada una de las seis materias primas testadas aportaba aproximadamente la sexta parte de la proteína dietaria. También en este caso se observó un aumento de las IgG frente a los antígenos presentes en los hidrolizados de las distintas materias primas incluidas en la dieta, aunque de menor magnitud que el observado con los piensos que contenían harina de girasol, gluten de trigo, guisante o harina de soja como única fuente proteica. Se sabe que la intensidad de la reacción inmunitaria frente a antígenos dietarios depende, entre otras cosas, de la cantidad y naturaleza del antígeno (Perrier y Corthesy, 2011). La diversificación del origen de la proteína dietaria entre varias fuentes proteicas y la consiguiente reducción de sus niveles de inclusión puede ser una estrategia para la reducción de las reacciones inmunitarias frente a la dieta.

El resultado de la ingestión de antígenos puede variar desde la inducción de tolerancia oral a la sensibilización sistémica, que generalmente se consideran mutuamente excluyentes (Strobel y Mowat, 1998). Sin embargo, aunque la tolerancia oral implica una reducción de la respuesta inmune, la ingestión de algunas proteínas todavía puede inducir una respuesta de anticuerpos, comparativamente débil y aparentemente fisiológica, en individuos sanos, sin signos de verdadera sensibilización sistémica; en otras palabras, la tolerancia oral y una respuesta de anticuerpos hacia un antígeno ingerido pueden coexistir tanto en humanos como en diferentes especies animales (Christensen et al., 2004).

En la presente tesis se ha desarrollado un método adecuado para valorar de forma sistemática la respuesta de anticuerpos frente a las materias primas proteicas utilizadas en la formulación de piensos para conejos, lo que permitiría estrategias encaminadas a la reducción de su antigenicidad mediante el uso de materias primas de baja antigenicidad, en la línea de lo indicado para lechones (Li et al., 1991a) y terneros (Lallès et al., 1995). Sin embargo, quedaría por dilucidar el significado real de las diferencias en la magnitud de esa respuesta entre las diferentes fuentes de proteína dietaria en conejos sanos.

\subsection{EFECTO DE LOS PIENSOS SOBRE LA MUCOSA INTESTINAL}

La variabilidad residual de los parámetros histomorfológicos de la mucosa yeyunal de gazapos de 29 días, 4 días después de comenzar la ingestión de los piensos experimentales, no permitió detectar diferencias significativas entre ellos, a pesar de que algunas fueran relevantes, como la mayor altura de las vellosidades y la mayor ratio altura de vellosidades/profundidad de criptas con el pienso de harina de pescado que con los de gluten de trigo y guisante. 
La información disponible sobre el efecto del origen de la proteína dietaria en la histomorfología de la mucosa yeyunal del conejo es escasa. Gutiérrez et al. (2000) observaron que la inclusión de plasma animal en lugar de harina de soja aumentó sobre todo la altura de las vellosidades pero también la profundidad de las criptas en gazapos de 35 días que llevaban 10 días consumiendo los piensos experimentales. Por el contrario, Gutiérrez et al. (2003) no observaron diferencias en la altura de las vellosidades, la profundidad de las criptas y la ratio entre ellas en gazapos de 35 días que llevaban 10 días consumiendo piensos con harina de girasol, harina de soja, concentrado proteico de soja o harina de soja + concentrado proteico de patata. En la misma línea, Trocino et al. (2010) tampoco observaron diferencias en los mismos parámetros de gazapos de 8 semanas que llevaban 3 semanas consumiendo piensos con harina de girasol o harina de soja.

Con los resultados obtenidos no es posible establecer una relación entre la morfología de la mucosa yeyunal y la intensidad de la respuesta de IgG circulantes asociadas a las materias primas testadas. Así, la harina de girasol y la harina de pescado indujeron, respectivamente, la máxima y mínima respuesta de IgG pero dieron lugar a parámetros histomorfológicos de la mucosa yeyunal muy similares. Esta relación tampoco es del todo clara en otras especies, como se verá a continuación. El origen de estas discrepancias estaría en la complejidad de las interacciones entre la dieta, la mucosa intestinal, la microbiota, el sistema inmunitario y la edad de los animales (Lallès et al., 2007).

En lechones, Li et al. (1990) observaron que la ingestión durante una semana de una dieta con harina de soja, en comparación con una dieta con leche descremada en polvo, se asoció a menor altura de las vellosidades duodenales y mayor respuesta de IgG periféricas frente a antígenos dietarios, con reversión del primero pero no del segundo de estos efectos cuatro semanas después. De forma análoga, Li et al. (1991a, 1991b) comprobaron que la ingestión durante una semana de una dieta con harina de soja indujo atrofia de las vellosidades duodenales (menor altura, perímetro y área), aumento de la profundidad de sus criptas y mayor respuesta de IgG periféricas frente a antígenos dietarios, en comparación no solo con la dieta con leche descremada en polvo sino también con dietas con distintos productos resultante del procesado de la soja, tales como el concentrado proteico de soja (obtenido mediante extracción alcohólica) convencional o extrusionado y el aislado proteico de soja (obtenido mediante tratamiento alcalino y precipitación ácida de la proteína). Por el contrario, en un experimento similar, comparando una dieta de harina de soja con otra de concentrado proteico de soja, Dréau et al. (1994) también encontraron reducción de la altura, el perímetro y el área de las vellosidades duodenales, pero no detectaron diferencias en la profundidad de las criptas o la respuesta de anticuerpos circulantes frente a antígenos dietarios. Por otro lado, Salgado et al. (2002a, 2002b) encontraron que, en comparación con una dieta con caseína, la ingestión de una dieta con harina de soja durante 4 semanas no afectó a la altura de las vellosidades intestinales pero aumentó su anchura, 
así como la profundidad y anchura de las criptas, sin detectar cambios en la respuesta de IgG periféricas frente a antígenos dietarios, mientras que otras leguminosas (guisantes, habas y altramuces) provocaron cambios muy similares en la mucosa intestinal acompañados de mayor respuesta de IgG periféricas frente a antígenos dietarios.

En terneros, se ha comprobado que la ingestión de una dieta con harina de soja durante 3 meses, en comparación con dietas con leche descremada en polvo o aislado proteico de soja hidrolizado, redujo la altura y el perímetro de las vellosidades yeyunales sin afectar a la profundidad de las criptas y aumentó las IgG circulantes frente a antígenos dietarios (Dréau et al., 1995a; Lallès et al., 1996). Por el contrario, Montagne et al. (1999) observaron que la ingestión de una dieta con harina de soja durante 8 semanas no afectó a la altura y anchura de las vellosidades yeyunales ni a la profundidad y anchura de sus criptas pero indujo una mayor respuesta de anticuerpos frente a antígenos dietarios que una dieta con concentrado proteico de soja.

Para tratar de profundizar en el efecto sobre la mucosa yeyunal, se realizaron estudios inmunohistoquímicos de la misma con tres de las fuentes proteicas testadas. Se escogieron por un lado la harina de pescado y por otro el gluten de trigo y el guisante porque dieron lugar a respuestas séricas de $\lg G$ frente a antígenos dietarios y a parámetros morfométricos de la mucosa yeyunal (altura de vellosidades y ratio altura de vellosidades/profundidad de criptas) divergentes. El gluten de trigo también se tuvo en consideración por su gran impacto negativo sobre el crecimiento de los gazapos.

El número de linfocitos $T$ (intraepiteliales y de la lámina propia) en las vellosidades de la mucosa yeyunal fue mayor en el caso de los gazapos que se alimentaron con el pienso de guisante, en comparación con aquéllos que recibieron los piensos de gluten de trigo o harina de pescado. No se ha encontrado información sobre el efecto de la fuente proteica en la infiltración linfocitaria de la mucosa intestinal en conejos, aunque sí en lechones y terneros.

Li et al. (1991a) observaron que la ingestión durante una semana de una dieta con harina de soja aumentó la densidad linfocitaria de las vellosidades duodenales de lechones, en comparación con dietas con leche descremada en polvo, concentrado proteico de soja (convencional o extrusionado) o aislado proteico de soja. En la misma línea, Dréau et al. (1995b) registraron un aumento del número de linfocitos T y B en las vellosidades duodenales de lechones alimentados con una dieta con harina de soja, en comparación con otra con concentrado proteico de soja. Por otro lado, la adición de una proteasa microbiana a una dieta con harina de soja para lechones redujo el número de linfocitos intraepiteliales en comparación con la dieta no suplementada con tal enzima (Dierick et al., 2004).

Lallès et al. (1996) observaron un aumento de los linfocitos $T$ intraepiteliales $y$, sobre todo, de linfocitos $\mathrm{T}$ y $\mathrm{B}$ en la lámina propia de la mucosa yeyunal de terneros alimentados durante 3 meses con una dieta con harina de soja, en comparación con 
dietas con leche descremada en polvo o aislado proteico de soja hidrolizado. En la misma línea, también en terneros, Verdonk et al. (2002) indican que las proteínas de las leguminosas inducen una respuesta local con aumento de la infiltración de linfocitos $T$ y B en la lámina propia de la mucosa intestinal.

En algunos trabajos (Li et al., 1991a; Verdonk et al., 2002), la mayor infiltración linfocitaria local se asocia al aumento de la respuesta humoral de IgG frente a la dieta. En el presente estudio, la infiltración de linfocitos $T$ y la presencia de IgG circulantes frente a antígenos dietarios fue claramente distinta entre el pienso con harina de pescado (baja) y el pienso con guisante (alta), pero el pienso con gluten de trigo dio lugar a baja infiltración linfocitaria y alta respuesta sérica de IgG.

Por otro lado, el número de células en división en las criptas fue mayor en los gazapos alimentados con el pienso de guisante que con el de gluten de trigo y con éste que con el de harina de pescado. Como el número de células no proliferantes disminuyó cuadráticamente con el aumento del número de células en división, el número total de células en las criptas fue mayor con el pienso de guisante que con los de gluten de trigo o harina de pescado. La proliferación celular en las criptas se asocia a un aumento de su profundidad y se interpreta como la respuesta necesaria para regenerar vellosidades atrofiadas (Blikslager et al., 2007); en este contexto, es reseñable que la profundidad de las criptas también fue mayor con el pienso de guisante que con los de gluten de trigo o harina de pescado (116 vs. $104 \mu \mathrm{m}, P=0,046$ ) y que tanto la altura de las vellosidades como la ratio entre la altura de las vellosidades y la profundidad de las criptas fueron menores con los piensos de guisante o gluten de trigo que con el de harina de pescado (448 vs. $559 \mu \mathrm{m}, P=0,025 ; 4,12$ vs. 5,38, $P=0,018$ ). El efecto de la fuente proteica sobre la proliferación celular en las criptas no ha sido estudiado en conejos y se dispone de poca información en otras especies. En terneros, Montagne et al. (1999) observaron que la proliferación celular en las criptas fue similar con dietas de harina de soja o concentrado proteico de soja suministradas durante 8 semanas y disminuyó en ambos casos tras 2 semanas suministrando una dieta con leche descremada en polvo.

Por último, debe señalarse que el número de células en división en las criptas aumentó linealmente con el número de linfocitos T en las vellosidades. Se sabe que la activación de los linfocitos $T$ estimula la proliferación celular en las criptas, como parte de la respuesta inmune local (Ferreira et al., 1990). Sin embargo, no se han encontrado trabajos que permitan relacionar la proliferación celular en las criptas con la respuesta periférica de IgG frente a antígenos dietarios. En el presente estudio el número de células no proliferantes y la respuesta de IgG circulantes frente a antígenos dietarios variaron en sentido inverso. Así, los piensos con gluten de trigo o guisante dieron lugar a bajos recuentos de células no proliferantes y alta respuesta de IgG mientras que el pienso con harina de pescado originó lo contrario. 


\subsection{INFLUENCIA DE LOS PIENSOS SOBRE LOS RENDIMIENTOS PRODUCTIVOS}

El presente estudio no se dimensionó para estudiar los efectos de las fuentes de proteína testadas sobre los parámetros productivos o el estado sanitario de los gazapos de cebo. Sin embargo, merecen destacarse los resultados obtenidos con los piensos de harina de pescado y gluten de trigo, que dieron lugar a ganancias de peso muy bajas, $25 \%$ y $67 \%$ menores que con los restantes piensos, respectivamente.

En el caso del pienso de harina de pescado es presumible que la ingestión registrada sea una sobreestimación de la real, ya que este pienso tenía mucha menor dureza y durabilidad que los restantes, lo que originaba abundantes pérdidas de harina y finos por el fondo perforado del comedero. Además, la aversión de los conejos por la harina y los finos está bien establecida (Acedo-Rico et al., 2010).

En el caso del pienso con gluten de trigo la hipótesis más razonable es una deficiencia en el aporte de arginina. En la formulación de los piensos se tuvo en cuenta el aporte de lisina, aminoácidos azufrados, treonina y triptófano, pero no el de isoleucina, valina y arginina. Los niveles de isoleucina y valina fueron muy similares en todos ellos (en torno a 5 y $5.8 \mathrm{~g} / \mathrm{kg} \mathrm{MS}$, respectivamente) pero el de arginina fue sensiblemente inferior en el pienso con gluten de trigo que en los restantes ( $3.3 \mathrm{vs} 8.1 \mathrm{~g} / \mathrm{kg}$ ), si bien no se dispone de información sobre las necesidades de arginina para gazapos en cebo.

Los resultados del presente estudio no permiten establecer una relación entre la respuesta de IgG frente a antígenos dietarios y/o los parámetros morfométricos o inmunohistoquímicos de la mucosa yeyunal con el crecimiento de los conejos. Las diferencias de crecimiento comentadas previamente no guardan relación con los aumentos de absorbancia en los sueros de los gazapos enfrentados al hidrolizado de la fuente proteica incluida en el pienso que habían consumido. Además, dentro de cada una de los piensos, la correlación entre tal aumento de absorbancia y el crecimiento de los gazapos no fue significativa, ni para el conjunto del cebo ni para ninguno de los periodos considerados $(25-29,30-33,34-46$ y $47-58$ días de vida), salvo para el pienso de guisante en el periodo 30-33 días de vida $(r=-0,706, P=0,010, \mathrm{n}=12$ ) y el pienso de harina de pescado en el periodo 34-46 días de vida $(r=+0,849, P<0,001, n=12)$. En lechones, se ha observado relación entre menor ganancia de peso en postdestete, mayor respuesta de IgG frente a antígenos dietarios y peor morfología de la mucosa con una dieta de harina de soja que con una de leche descremada en polvo, pero no al compararla con dietas con concentrado proteico de soja (convencional o extrusionado) o aislado proteico de soja, observándose globalmente falta de correlación entre el nivel de IgG anti-soja circulante y la ganancia media diaria en postdestete, positivamente correlacionada con la altura de las vellosidades duodenales (Li et al., 1991a; Li et al., 1991b; Li et al., 1990). En terneros, Montagne et al. (1999) no encontraron diferencias de crecimiento con harina de soja o concentrado proteico de soja a pesar de su diferente capacidad para inducir anticuerpos frente a antígenos dietarios. 
6. CONCLUSIONES 

En el presente trabajo:

1. Se ha desarrollado un ELISA indirecto para determinar anticuerpos IgG frente a antígenos dietarios en suero sanguíneo de conejos, utilizando como antígeno para el tapizado de los pocillos un hidrolizado del pienso o la materia prima proteica estudiada obtenido mediante digestión pépsica.

2. Se ha detectado la presencia de anticuerpos IgG frente a antígenos dietarios en el suero sanguíneo de conejas adultas y de gazapos estrictamente lactantes.

3. Se ha comprobado que la respuesta de anticuerpos IgG frente a antígenos dietarios en el suero sanguíneo de los gazapos de cebo depende de la materia prima proteica incluida en el pienso que han consumido durante dicho periodo, siendo sensiblemente mayor con harina de girasol, gluten de trigo, guisante y harina de soja que con heno de alfalfa y, sobre todo, que con harina de pescado.

4. Se ha observado que el pienso formulado con una combinación proporcional de todas las materias primas proteicas estudiadas dio lugar a una respuesta de anticuerpos lgG frente a los antígenos de las mismas de menor intensidad que en el caso de los piensos formulados con harina de girasol, gluten de trigo, guisante o harina de soja como una única materia prima proteica.

5. No se ha podido establecer una relación consistente de la respuesta de anticuerpos IgG frente a antígenos dietarios en suero sanguíneo ni con los parámetros histomorfológicos (altura de vellosidades, profundidad de criptas y ratio entre ellas) o inmunohistoquímicos (recuentos de linfocitos $T$ en las vellosidades y de células en división en las criptas) de la mucosa yeyunal ni con el crecimiento durante el cebo.

6. Se ha observado que el número de células en división en las criptas aumenta linealmente con el número de linfocitos $T$ en las vellosidades, siendo ambos valores mayores cuando la fuente proteica del pienso era guisante que cuando era gluten de trigo o harina de pescado. 

7. IMPLICACIONES 

Uno de los principales retos de la producción cunícola sigue siendo la salud digestiva y, en este contexto, sería importante dilucidar en qué medida y de qué forma puede verse afectada por la respuesta inmune del gazapo frente a los antígenos de origen dietario.

Sin embargo, la significación fisiológica, sanitaria y productiva de la respuesta de anticuerpos IgG frente a antígenos dietarios en el suero sanguíneo de gazapos de cebo, variable en función de la fuente de proteína dietaria, así como su persistencia en conejas adultas y su transferencia vertical a la descendencia, está por determinar y requiere más investigación. Disponer de una herramienta para valorar esta respuesta periférica puede ser de utilidad para tratar de relacionarla con la respuesta local a nivel de la mucosa intestinal y sus consecuencias sobre la inmunocompetencia, la salud y el rendimiento productico de los gazapos durante el cebo.

Los futuros avances en el conocimiento de la respuesta inmunitaria frente a los antígenos dietarios podrían permitir, como sucede en lechones y terneros, establecer recomendaciones nutricionales en cunicultura encaminadas a la reducción del uso de materias primas antigénicas durante la lactancia y el postdestete como una de las formas de reducir el riesgo de problemas digestivos y retraso del crecimiento. 

8. BIBLIOGRAFÍA 

Abreau-Martin M.T. y Targan S.R. 1996. Regulation of immune responses of the intestinal mucosa. Critical Reviews in Immunology 16: 227-309.

Acedo-Rico J., Méndez J. y Santomá G. 2010. Feed manufacturing. En: The Nutrition of the Rabbit, 2nd ed., C. de Blas y J. Wiseman (Eds.), CABI, Wallingford, UK, pp. 200-221.

Alpers D.H. 1994. Digestion and absorption of carbohydrates and proteins. En: Physiology of the Gastrointestinal Tract, 3rd ed., Raven Press, New York, USA, pp. 1723-1749.

AOAC 2000. Official methods of analysis of the AOAC. Association of Official Analytical Chemists, 17th ed., AOAC International, Gaithersburg, MD, USA.

Arvola M., Gustafsson E.,Svensson L., Jansson L., Holmdahl R., Heyman B., Okabe M. y Mattsson R. 2000. Immunoglobulin secreting cells of maternal origin can be detected in $B$ cell deficient mice. Biology of Reproduction 63: 1817-1824.

Bailey M. y Haverson K. 2006. The postnatal development of the mucosal immune system and mucosal tolerance in domestic animals. Veterinary Research 37: 443-453.

Bailey M., Haverson K., Miller B., Jones P., Sola I., Enjuanes L. y Stokes C.R. 2004. Effects of infection with transmissible gastroenteritis virus on concomitant immune responses to dietary and injected antigens. Clinical and Diagnostic Laboratory Immunology 11: 337343.

Bailey M., Miller B.G., Telemo E., Stokes C.R. y Bourne F.J. 1994. Altered immune response to proteins fed after neonatal exposure of piglets to the antigen. International Archives of Allergy and Immunology 103: 183-187.

Bailey M., Plunkett F.J., Rothkötter H.J., Vega-López M.A., Haverson K. y Stokes C.R. 2001. Regulation of mucosal immune responses in effector sites. Proceedings of the Nutrition Society 60: 427-435.

Batey I.L. 1982. Starch analysis using thermostable alpha-amylases. Starch 34: 125-128.

Bednar-Tantscher E., Mudde G.C. y Rot A. 2001. Maternal antigen stimulation downregulates via mother's milk the specific immune responses in young mice. International Archives of Allergy and Immunology 126: 300-308.

Berin M.C. 2012. Mucosal antibodies in the regulation of tolerance and allergy to foods. Seminars in Immunopathology 34: 633-642.

Blikslager A.T, Moeser A.J., Gookin J.L., Jones S.L. y Odle J. 2007. Restoration of barrier function in injured intestinal mucosa. Physiological Reviews 87: 545-564.

Brandtzaeg P.E. 2002. Current understanding of gastrointestinal immunoregulation and its relation to food allergy. Annals of the New York Academy of Sciences 964: 13-45.

Brenes A. y Brenes J. 1993. Tratamiento tecnológico de los granos de leguminosas: influencia sobre su valor nutritivo. En: IX Curso de Especialización FEDNA, Avances en Nutrición y Alimentación Animal, P. G. Rebollar, C. De Blas y G.G. Mateos (Eds.), Fundación Española para el Desarrollo de la Nutrición Animal, Madrid, España, pp. 199-232. 
Carabaño R., Villamide M.J., García J., Nicodemus N., Llorente A., Chamorro S., Menoyo D., García-Rebollar P., García-Ruiz A.I. y De Blas J.C. 2009. New concepts and objectives for protein-amino acid nutrition in rabbits: a review. World Rabbit Science 17: 1-14.

Castro-Sánchez P. y Martín-Villa J.M. 2013. Gut immune system and oral tolerance. British Journal of Nutrition 109 Suppl. 2: S3-S11.

Cave N.J. 2006. Hydrolyzed protein diets for dogs and cats. Veterinary Clinics of North America: Small Animal Practice 36: 1251-1268.

Chamorro S., Gómez-Conde M.S., Pérez de Rozas A.M., Badiola I., Carabaño R. y De Blas J.C. 2007. Effect on digestion and performance of dietary protein content and of increased substitution of lucerne hay with soya-bean protein concentrate in starter diets for young rabbits. Animal 1: 651-659.

Christensen H.R., Brix S. y Frokiaer H. 2004. Immune response in mice to ingested soya protein: antibody production, oral tolerance and maternal transfer. British Journal of Nutrition 91: 725-732.

Coombes J.L. y Powrie F. 2008. Dendritic cells in intestinal immune regulation. Nature Reviews Immunology 8: 435-446.

Corring T., Lebas F. y Courtot D. 1972. Contrôle de l'évolution de l'équipement enzymatique du pancréas exocrine du lapin de la naissance à 6 semaines. Annales de Biologie Animale, Biochimie et Biophysique 12: 221-231.

Cortez S., Brandenburger H., Greuel E. y Sundrum A. 1992. Studies on the gut flora of rabbits as influenced by diet and health status. Tierärztliche Umschau 47: 544-549.

De Blas J.C. y Mateos G.G. 1998. Feed formulation. En: The Nutrition of the Rabbit, C. de Blas y J. Wiseman (Eds.), CABI, Wallingford, UK, pp. 241-253.

De Blas J.C, Gutiérrez I. y Carabaño R. 1999. Destete precoz en gazapos. Situación actual y perspectivas. En: XV Curso de Especialización FEDNA, Avances en Nutrición y Alimentación Animal, P.G. Rebollar, C. De Blas y G.G. Mateos (Eds.), Fundación Española para el Desarrollo de la Nutrición Animal, Madrid, España, 14 pp.

De Blas J.C., Mateos G.G. y Rebollar P.G. 2010. Tablas FEDNA de composición y valor nutritivo de alimentos para la fabricación de piensos compuestos (3a Edición). Fundación Española para el Desarrollo de la Nutrición Animal, Madrid, España.

Debray L., Le Huerou-Luron I., Gidenne T. y Fortun-Lamothe L. 2003. Digestive tract development in rabbit according to the dietary energetic source: correlation between whole tract digestion, pancreatic and intestinal enzymatic activities. Comparative Biochemistry and Physiology Part A: Molecular and Integrative Physiology 135: 443-455.

Delves P.J., Martin S.J., Burton R.D. y Roitt I.M. 2011. Essential Immunology, $12^{\text {th }}$ ed., WileyBlackwell, Oxford, UK.

Dierick N., Decuypere J., Molly K. y Vanderbeke E. 2004. Microbial protease addition to a soybean meal diet for weaned piglets: effects on performance, digestion, gut flora and gut 
function. European Federation of Animal Science (EAAP), Publication 110, Wageningen

Academic Publishers, Wageningen, pp. 229-233.

Dojana N., Costache M. y Dinischiotu A. 1998. The activity of some digestive enzymes in domestic rabbits before and after weaning. Animal Science 66: 501-507.

Dréau D. y Lallès J.P. 1999. Contribution to the study of gut hypersensitivity reactions to soybean proteins in preruminant calves and early-weaned piglets. Livestock Production Science 60: 209-218.

Dréau D., Lallès J.P., Philouze-Romé V., Toullec R. y Salmon H. 1994. Local and systemic immune responses to soybean protein ingestion in early-weaned pigs. Journal of Animal Science 72: 2090-2098.

Dréau D., Lallès J.P., Salmon H. y Toullec R. 1995a. IgM, IgA, IgG1 and IgG2 specific responses in blood and gut secretion of calves fed soyabean products. Veterinary Immunology and Immunopathology 47: 57-67.

Dréau D., Lallès J.P., Toullec R y Salmon H. 1995b. B and T lymphocytes are enhaced in the gut of piglets fed heat-treated soyabean proteins. Veterinary Immunology and Immunopathology 47: 69-79.

Drouet-Viard F. y Fortun-Lamothe L. 2002. The organization and functioning of the immune system: particular features of the rabbit. World Rabbit Science 10: 15-23.

Edder P., Cominoli A. y Corvi C. 1999. Determination of streptomycin residues in food by solidphase extraction and liquid chromatography with post-column derivatization and fluorometric detection. Journal of Chromatography A 830: 345-351.

Engvall E. y Perlmann P. 1971. Enzyme-linked immunosorbent assay (ELISA). Quantitative assay of immunoglobulin G. Immunochemistry 8: 871-874.

Ermark T.H., Bhagat H.R. y Pappo J. 1994. Lymphocyte compartments in antigen-sampling regions of rabbit mucosal lymphoid organs. American Journal of Tropical Medicine and Hygiene 50: 14-28.

Falcao-e-Cunha, Castro-Solla L., Maertens L., Marounek M., Pinheiro V., Freire J. y Mourao J.L. 2007. Alternatives to antibiotic growth promoters in rabbit feeding: a review. World Rabbit Science 15: 127-140.

Ferreira R.C., Forsyth L.E., Richman P.I., Wells C., Spencer J. y MacDonald T.T. 1990. Changes in the rate of crypt epithelial proliferation and mucosal morphology induced by a T-cell mediated response in human small intestine. Gastroenterology 98: 1255-1263.

Fortun-Lamothe L. y Boullier S. 2007. A review on the interactions between gut microflora and digestive mucosal immunity. Possible ways to improve the health of rabbits. Livestock Science 107: 1-18.

Gallois M., Gidenne T., Fortun-Lamothe L., Le Huërou-Luron I. y Lallès J.P. 2005. An early stimulation of solid feed intake slightly influences the morphological gut maturation in the rabbit. Reproduction Nutrition Development 45: 109-122. 
Gallois M., Le Huërou-Luron I., Fortun-Lamothe L., Lallès J.P. y Gidenne T. 2008. Adaptability of the digestive function according to age at weaning in the rabbit: I. Effect on feed intake and digestive functionality. Animal 2: 525-535.

García-Palomares J., Carabaño R., García-Rebollar P., Blas J.C., Corujo A. y García-Ruiz A.I. 2006. Effects of a dietary protein reduction and enzyme supplementation on growth performance in the fattening period. World Rabbit Science 14: 231-236.

Gidenne T. y Fortun-Lamothe L. 2002. Feeding strategy for young rabbits around weaning: a review of digestive capacity and nutritional needs. Animal Science 75: 169-184.

Gidenne T., García J., Lebas F. y Licois D. 2010. Nutrition and feeding strategy: interactions with pathology. En: The Nutrition of the Rabbit, 2nd ed., C. de Blas y J. Wiseman (Eds.), CABI, Wallingford, UK, pp. 179-199.

Gidenne T., Kerdiles V., Jehl N., Arveux P., Eckenfelder B., Briens C., Stephan S., Fortune H., Montessuy S. y Muraz G. 2013. Protein replacement by digestible fibre in the diet of growing rabbits. 2. Impact on performances, digestive health and nitrogen output. Animal Feed Science and Technology 183: 142-150.

Girotti S., Eremin S., Montoya A., Moreno M.J., Caputo P., D’Elia M., Ripani L., Romolo F.S. y Maiolini E. 2010. Development of a chemiluminescent ELISA and a colloidal gold-based LFIA for TNT detection. Analytical and Bioanalytical Chemistry 396: 687-695.

Granucci F. y Ricciardi-Castagnoli P. 2003. Interactions of bacterial pathogens with dendritic cells during invasion of mucosal surfaces. Current Opinion in Microbiology 6: 72-76.

Gutiérrez I., Espinosa A., García J., Carabaño R. y De Blas J.C. 2002. Effect of levels of starch, fiber and lactose on digestion and growth performance of early-weaned rabbits. Journal of Animal Science 80: 1029-1037.

Gutiérrez I., Espinosa A., García J., Carabaño R. y De Blas J.C. 2003. Effect of protein source on digestion and growth performance of early-weaned rabbits. Animal Research 52: 461471.

Gutiérrez I., García P., Carabaño R. y De Blas J.C. 2000a. Effect of supplementation with animal plasma and antibiotics of starter diets in rabbits. World Rabbit Science 8 (Supp I C): 269275.

Gutiérrez I., García P., Carabaño R. y De Blas J.C. 2000b. Effect of supplementation with animal plasma and antibiotics on jejunal morphology of early-weaned rabbits. World Rabbit Science 8 (Supp I C): 263-267.

Haffar A., Laval A. y Guillou J.P. 1988. Clostridium spiroforme enterotoxaemia in adult rabbits. Point Veterinaire 20: 99-102.

Hankins C.C., Noland P.R., Burks A.W.Jr., Connaughton C., Cockrell G. y Metz C.L. 1992. Effect of soy protein ingestion on total and specific immunoglobulin $G$ concentrations in neonatal porcine serum measured by enzyme-linked immunosorbent assay. Journal of Animal Science 70: 3096-3101. 
Hofmaier S., Comberiati P. y Matricardi P.M. 2014. Immunoglobulin G in IgE-mediated allergy and allergen-specific immunotherapy. European Annals of Allergy and Clinical Immunology 46: 6-11.

Hornbeck P., Winston S.E. y Fuller S.A. 1991. Enzyme-Linked Immunosorbent Assays (ELISA) in Molecular Biology, John Wiley \& Sons Ltd., Oxford, UK, Supplement 15, Unit 11.2, pp. 122.

Huisman J. y Jansman A.J.M. 1991. Dietary effects and some analytical aspects of antinutritional factors in peas (Pisum sativum), common beans (Phaseolus vulgaris) and soyabeans (Glycine max L.) in monogastric farm animals. A literature review. Nutrition Abstracts and Reviews. Series B, Livestock Feeds and Feeding 61: 901-921.

Husby S. 1988. Dietary antigens: uptake and humoral immunity in man. Acta Pathologica, Microbiologica et Immunologica Scandinavica Suppl. 1: 1-40.

Husby S. 2000. Normal immune responses to ingested foods. Journal of Pediatric Gastroenterology and Nutrition 30: S13-S19.

Jang M.H., Kweon M.N., Iwatani K., Yamamoto M., Terahara K., Sasakawa C., Suzuki T., Nochi T., Yokota Y., Rennert P.D., Hiroi T., Tamagawa H., lijima H., Kunisawa J., Yuki Y. y Kiyono H. 2004. Intestinal villous $M$ cells: an antigen entry site in the mucosal epithelium. Proceedings of the National Academy of Sciences of the United States of America 101: 6110-6115.

Kagnoff M.F. 1993. Immunology of the intestinal tract. Gastroenterology 105: 1275-1280.

Klis J.D. van der y Jansman A.J.M. 2002. Optimising nutrient digestion, absorption and gut barrier function in monogastrics: reality or illusion?. En: M.H. Blok, H.A. Vahl, L. de Lange, A.E. van de Braak, G. Hemke y M. Hessing (Eds.), Nutrition and Health of the Gastrointestinal Tract, Wageningen Academic Publishers, Wageningen, The Netherlands, pp. 15-36.

Knippels L.M., Penninks A.H. y Houben G.F. 1998. Continued expression of anti-soy protein antibodies in rats bred on a soy protein free diet for one generation: the importance of dietary control in oral sensitization research. Journal of Allergy and Clinical Immunology 101: 815-820.

Krehbiel C.R. y Matthews J.C. 2003. Absorption of amino acids and peptides. En: Amino Acids in Animal Nutrition, 2nd ed., J.P.F. D'Mello (Ed.), CABI, Wallingford, UK, pp. 41-70.

Lallès J.P. 2008. Nutrition and gut health of the young pig around weaning: what news?. Archiva Zootechnica 11: 5-15.

Lallès J.P., Bosi P., Smidt H. y Stokes C.R. 2007. Weaning: a challenge to gut physiologists. Livestock Science 108: 82-93.

Lallès J.P., Dréau D., Féménia F., Parodi A.L. y Toullec R. 1996. Feeding heated soyabean flour increases the density of $B$ and $T$ lymphocytes in the small intestine of calves. Veterinary Immunology and Immunopathology 52: 105-115. 
Lallès J.P., Dréau D., Huet A. y Toullec R. 1995a. Systemic and local gut-specific antibody responses in preruminant calves sensitive to soya. Research in Veterinary Science 59: 56-60.

Lallès J.P., Salgado P. y Freire J.P.B. 2004. Plasma antibody responses to grain legume proteins in weaned piglets. European Federation of Animal Science (EAAP), Publication 110, Wageningen Academic Publishers, Wageningen, pp. 181-184.

Lallès J.P., Toullec R., Branco-Pardal P. y Sissons J.W. 1995b. Hydrolyzed soy protein isolate sustains high nutritional performance in veal calves. Journal of Dairy Science 78: 204.

Lamm M.E. 1997. Interaction of antigens and antibodies at mucosal surfaces. Annual Review of Microbiology 3: 947-954.

Lebas F., Corring T. y Courtot D. 1971. Équipement enzymatique du pancréas exocrine chez le lapin, mise en place et évolution de la naissance au sevrage. Relation avec la composition du régime alimentaire. Annales de Biologie Animale, Biochimie, et Biophysique 11: 339-413.

Lehninger A., Nelson D. y Cox M. 2008. Principles of Biochemistry. W. H. Freeman, New York, USA.

Li D.F, Nelssen J.L., Reddy P.G., Blecha F., Hancock J.D., Allee G.L., Goodband R.D. y Klemm R.D. 1990. Transient hypersensitivity to soybean meal in the early-weaned pig. Journal of Animal Science 68: 1790-1799.

Li D.F., Nelssen J.L., Reddy P.G., Blecha F., Klemm R. y Goodband R.D. 1991a. Interrelationship between hypersensitivity to soybean proteins and growth performance in early-weaned pigs. Journal of Animal Science 69: 4062-4069.

Li D.F., Nelssen J.L., Reddy P.G., Blecha F., Klemm R.D., Giesting D.W., Hancock J.D., Allee G.L. y Goodband R.D. 1991b. Measuring suitability of soybean products for early weaned pigs with immunological criteria. Journal of Animal Science 69: 3299-3307.

Mage R. 1998. Immunology of lagomorphs. Handbook of vertebrate immunology. Academic Press, San Diego, CA, USA.

March J.B. 2003. High antigliadin IgG titers in laboratory rabbits fed a wheat-containing diet: a model for celiac disease?. Digestive Diseases and Sciences 48: 608-610.

Marounek M., Vovk S.J. y Skrivanova V. 1995. Distribution of activity of hydrolytic enzymes in the digestive tract of rabbits. British Journal of Nutrition 73: 463-469.

Martínez-Vallespín B. 2011. Use of weaning diets in combined feeding of females and growing rabbits. Tesis Doctoral, Departamento de Ciencia Animal, Universidad Politécnica de Valencia, Valencia, España.

Martínez-Vallespín B. 2012. Alimentación y riesgo de enteropatía. Cunicultura 216: 19-22.

Mason K.L., Huffnagle G.B., Noverr M.C. y Kao J.Y. 2008. Overview of gut immunology. Advances in Experimental Medicine and Biology 635: 1-14. 
Mehrez A.Z., Orskov E.R. y Opstvedt J. 1980. Processing factors affecting degradability of fish meal in the rumen. Journal of Animal Science 50: 737-744.

Miller B.G., Whittemore C.T., Stokes C.R. y Telemo E. 1994. The effect of delayed weaning on the development of oral tolerance to soya-bean protein in pigs. British Journal of Nutrition 71: 615-625.

Moens E. y Veldhoen M. 2012. Epithelial barrier biology: good fences make good neighbours. Immunology 135: 1-8.

Montagne L., Toullec R., Savidge T. y Lallès J.P. 1999. Morphology and enzyme activities of the small intestine are modulated by dietary protein source in the preruminant calf. Reproduction Nutrition Development 39: 455-466.

Neutra M.R. y Kozlowski P.A. 2006. Mucosal vaccines: the promise and the challenge. Nature Reviews Immunology 6: 148-158.

Neutra M.R., Philips T.L., Mayer E.L. y Fishkind D.J. 1987. Transport of membrane-bound macromolecules by $M$ cells in follicle-associated epithelium of rabbit Peyer's patch. Cell and Tissue Research 247: 537-546.

Newberry R.D., Stenson W.F. y Lorenz R.G. 1999. Cyclooxigenase-2-dependent arachidonic acid metabolites are essential modulators of the immune response to dietary antigen. Nature Medicine 5: 900-906.

Niess J.H., Brand S., Gu X., Landsman L., Jung S., McCormick B.A., Vyas J.M., Boes M., Ploegh H.L., Fox J.G., Littman D.R. y Reinecker H.C. 2005. CX3CR1-mediated dendritic cell access to the intestinal lumen and bacterial clearance. Science 307: 254-258.

Orr R.M. 2003. Applied animal nutrition. En: The Agricultural Notebook, R. J. Soffe (Ed.), Blackwell Science, Oxford, UK, pp. 443-472.

Owen R.L. y Bahalla D.K. 1983. Cytochemical analysis of alkaline phosphatase and esterase activities and of lectin-binding and anionic sites in rat and mouse Peyer's patch $\mathrm{M}$ cells. Journal of Anatomy 168: 199-212.

Pappo J. 1989. Generation and characterization of monoclonal antibodies recognizing follicle epithelial M cells in rabbit gut associated lymphoid tissues. Cellular Immunology 120: 3141.

Pappo J. y Owen R.L. 1988. Absence of secretory component expression by epithelial cells overlying rabbit gut-associated lymphoid issue. Gastroenterology 95: 1173-1177.

Perrier C. y Corthesy B. 2011. Gut permeability and food allergies. Clinical and Experimental Allergy 41: 20-28.

Pié S., Lallès J.P., Blazy F., Laffitte J., Sève B. y Oswald I.P. 2004. Weaning is associated with an upregulation of expression of inflammatory cytokines in the intestine of piglets. Journal of Nutrition 134: 641-647. 
Pluske J.R., Hampson D.J. y Williams I.H. 1997. Factors influencing the structure and function of the small intestine in the weaned pig: a review. Livestock Production Science 51: 215236.

Ramiro-Puig E., Pérez-Cano F.J., Castellote C., Franch A. y Castell M. 2008. El intestino: pieza clave del sistema inmunitario. Revista Española de Enfermedades Digestivas 100: 29-34.

Ramos M.A., Carabaño R. y Boisen S. 1992. An in vitro method for estimating digestibility in rabbits. Journal of Applied Rabbit Research 15: 938-946.

Rescigno M., Urbano M., Valzasina B., Francolini M., Rotta G., Bonasio R., Granucci F., Kraehenbuhl J.P. y Ricciardi-Castagnoli P. 2001. Dendritic cells express tight junction proteins and penetrate gut epithelial monolayers to sample bacteria. Nature Immunology 2: 361-367.

Rothberg R.M. y Farr R.S. 1965. Anti-bovine serum albumin and anti-alpha lactalbumin in the serum of children and adults. Pediatrics 35: 571-588.

Salgado P., Freire J.B., Ferreira R.B., Seabra M.,Teixeira A.R.,Toullec R. y Lallès J.P. 2002a. Legume proteins of the vicilin family are more immunogenic than those of the legumin family in weaned piglets. Food and Agricultural Immunology 14: 51-63.

Salgado P., Freire J.P.B., Mourato M., Cabral F., Toullec R. y Lallès J.P. 2002b. Comparative effects of different legume protein sources in weaned piglets: nutrient digestibility, intestinal morphology and digestive enzymes. Livestock Production Science 74: 191-202.

Scheele C.W. y Bolder N.M. 1987. Health problems and mortality of young suckling rabbits in relation to dietary composition. En: Rabbit Production Systems including Welfare, Commission of the European Communities, Bruselas, Bélgica, pp. 115-125.

Scortichini G., Annunziata L., Haouet M.N., Benedetti F., Krusteva I. y Galarini R. 2005. ELISA qualitative screening of chloramphenicol in muscle, eggs, honey and milk: method validation according to the Commission Decision 2002/657/EC criteria. Analytica Chimica Acta 535: 43-48.

Scott H., Rognum T.O., Midtvedt T. y Brandtzaeg P. 1985. Age-related changes of human serum antibodies to dietary and colonic bacterial antigens measured by an enzyme-linked immunosorbent assay. Acta Pathologica, Microbiologica et Immunologica Scandinavica 93: 65-67.

Siebers A. y Finlay B.B. 1996. M Cells and the pathogenesis of mucosal and systemic infections. Trends in Microbiology 4: 22-29.

Snoeck V., Goddeeris B. y Cox E. 2005. The role of enterocytes in the intestinal barrier function and antigen uptake. Microbes and Infection 7: 997-1004.

Soler M.D. 2014. Efectos de la inclusión de fibra fermentable en sustitución de almidón y del nivel de grasa animal en el pienso sobre el rendimiento productivo y los parámetros digestivos de conejos en crecimiento. Tesis Doctoral, Universidad CEU-Cardenal Herrera, Moncada, Valencia, España. 
Statistical Analysis Systems Institute 2002. SAS/STAT User Guide (Release 9.2). SAS Inst. Inc., Cary, NC, USA.

Stojanovic B., Grubic G., Dordevic N., Levic J., Bozickovic A. y Ivetic A. 2010. Soybean and its processing products in the nutrition of calves. En: 2nd Workshop Feed-to-Food, Extrusion technology in feed and food processing, Institute for Food Technology, Novi Sad, Serbia, pp. 117-138.

Stokes C.R., Bailey M., Haverson K., Harris C., Jones P., Inman C., Pié S., Oswald I.P., Williams B.A., Akkermans A.D.L., Sowa E., Rothkötter H.J. y Miller B.G. 2004. Postnatal development of intestinal immune system in piglets: implications for the process of weaning. Animal Research 53: 325-334.

Strobel S. y Mowat A.M. 1998. Immune responses to dietary antigens: oral tolerance. Immunology Today 19: 173-181.

Telemo E., Bailey M., Miller B.G., Stokes C.R. y Bourne F.J. 1991. Dietary antigen handling by mother and offspring. Scandinavian Journal of Immunology 34: 689-696.

Timmermans M., Kupers L. y Teuchy H. 1992. Detection of wheat proteins in feed. En: Food safety and quality assurance, applications of immunoassay systemsm Bowness-onWindermere, Cumbria, UK, pp. 69-70.

Tizard I. 2013. Veterinary Immunology: An introduction. 9th ed., Ed. Saunders, Philadelphia.

Touchette K.J., Allee G.L., Newcomb M.D., Pace L.W. y Ellersieck M.R. 1997. Effect of feed intake and spray-dried plasma on nursery performance and intestinal morphology of weaned pigs. Journal of Animal Science 75 Suppl. 1: 198.

Trocino A., Fragkiadakis M., Majolini D., Tazzoli M., Radaelli G. y Xiccato G. 2013. Soluble fibre, starch and protein level in diets for growing rabbits: effects on digestive efficiency and productive traits. Animal Feed Science and Technology 180: 73-82.

Trocino A., Fragkiadakis M., Radaelli G. y Xiccato G. 2010. Effect of dietary soluble fibre level and protein source on growth, digestion, caecal activity and health of fattening rabbits. World Rabbit Science 18: 199-210.

Turner J.R. 2009. Intestinal mucosal barrier function in health and disease. Nature Reviews Immunology 9: 799-809.

Untersmayr E., Scholl I., Swoboda I., Beil W.J., Forster-Waldl E., Walter F., Riemer A., Kraml G., Kinaciyan T., Spitzauer S., Boltz-Nitulescu G., Scheiner O. y Jensen-Jarolim E. 2003. Antacid medication inhibits digestion of dietary proteins and causes food allergy: a fish allergy model in BALB/c mice. Journal of Allergy and Clinical Immunology 112: 616-623.

Van Soest P.J., Robertson J.R. y Lewis B.A 1991. Methods for dietary fiber, neutral detergent fiber and nonstarch polysaccharides in relation to animal nutrition. Journal of Dairy Science 74: 3583-3597.

Van N.G., Mallegol J., Bevilacqua C., Candalh C., Brugiere S., Tomaskovic-Crook E., Heath J.K., Cerf-Bensussan N. y Heyman M. 2003. Intestinal epithelial exosomes carry MHC class II/peptides able to inform the immune system in mice. Gut 52: 1690-1697. 
Vente-Spreeuwenberg M.A.M. y Beynen A.C. 2003. Diet-mediated modulation of small intestinal integrity in weaned piglets. En: Weaning the pig. Concepts and consequences, J.R. Pluske, J. Le Dividich y M.W.A. Verstegen (Eds.), Wageningen Academic Publishers, Wageningen, The Netherlands, pp. 145-198.

Vente-Spreeuwenberg M.A.M., Verdonk J.M.A.J., Koninkx J.F.J.G., Beynen A.C. y Verstegen M.W.A. 2004. Dietary protein hydrolysates vs. the intact proteins do not enhance mucosal integrity and growth performance in weaned piglets. Livestock Production Science 85: 151-164.

Verdonk J.M.A.J., Gerrits W.J.J. y Beynen A.C. 2002. Replacement of milk protein by vegetable protein in milk replacer diets for veal calves: digestion in relation to intestinal health. En: M.H. Blok, H.A. Vahl, L. de Lange, A.E. van de Braak, G. Hemke y M. Hessing (Eds.), Nutrition and Health of the Gastrointestinal Tract, Wageningen Academic Publishers, Wageningen, The Netherlands, pp. 183-198.

Viana D. 2009. Estafilococia en conejos: relación entre genotipos, virulencia y lesiones. Tesis Doctoral, Universidad CEU-Cardenal Herrera, Moncada, Valencia, España.

Villamide M.J., Nicodemus N., Fraga M.J. y Carabaño R. 2010. Protein digestion. En: The Nutrition of the Rabbit, 2nd ed., C. de Blas y J. Wiseman (Ed.), CABI, Wallingford, UK, pp. 39-55.

Wilfart A., Jaguelin-Peyraud Y., Simmins H., Noblet J., Van Milgen J. y Montagne L. 2008. Kinetics of enzymatic digestion of feeds as estimated by a stepwise in vitro method. Animal Feed Science and Technology 141: 171-183.

Willis-Mahn C., Remillard R. y Tater K. 2014. ELISA testing for soy antigens in dry dog foods used in dietary elimination trials. Journal of the American Animal Hospital Association 50: 383-389.

Xiccato G., Trocino A., Majolini D., Fragkiadakis M. y Tazzoli M. 2011. Effect of decreasing dietary protein level and replacing starch with soluble fibre on digestive physiology and performance of growing rabbits. Animal 5: 1179-1187.

Xiccato G., Trocino A., Sartori A. y Queaque P.I. 2004. Effect of parity order and litter weaning age on the performance and body energy balance of rabbit does. Livestock Production Science 85: 239-251. 